\title{
Grondslagen en strafprocessuele gevolgen van de geheimhoudingsplicht en het verschoningsrecht van de arts, advocaat en notaris
}

\author{
Tom Bertens en Feikje Vellinga-Schootstra*
}

\section{Inleiding}

Artsen, advocaten en notarissen kunnen zich, indien zij in een strafzaak voor de rechter(-commissaris) als getuige zijn opgeroepen, met een beroep op artikel 2I8 Wetboek van Strafvordering (Sv) verschonen van de verplichting om een verklaring af te leggen. Volgens vaste rechtspraak berust het in deze bepaling tot uiting gebrachte verschoningsrecht op een algemeen rechtsbeginsel. Ook in het procesrecht op andere rechtsgebieden is dit verschoningsrecht wettelijk vastgelegd. Uit het uitgangspunt dat sprake is van een algemeen rechtsbeginsel wordt afgeleid dat de interpretatie van het verschoningsrecht per rechtsgebied in beginsel niet veel zal verschillen. Dit stuk behandelt het verschoningsrecht evenwel vanuit strafrechtelijk perspectief.

Het hier besproken verschoningsrecht biedt de mogelijkheid om de vertrouwelijkheid van bepaalde in het kader van de beroepsuitoefening toevertrouwde informatie ook ten overstaan van de rechter te garanderen. Deze mogelijkheid zou gemakkelijk kunnen worden omzeild als politie en justitie zich door toepassing van dwangmiddelen als inbeslagneming of het opnemen van telefoonverkeer alsnog en zonder toestemming toegang tot die informatie kunnen verschaffen. In de wet is de toepassing van dergelijke dwangmiddelen om die reden aan beperkingen gebonden. Om dezelfde reden zijn de hier besproken beroepsgroepen vrijgesteld van de verplichtingen om aangifte te doen van (samenspanningen tot) het plegen van bepaalde ernstige strafbare feiten.

Dit stuk bestaat uit twee delen. In het eerste deel bespreekt Bertens de grondslag en de reikwijdte van het verschoningsrecht van artsen, advocaten en notarissen.

Tom Bertens is als gerechtsauditeur verbonden aan het wetenschappelijk bureau van de Hoge Raad der Nederlanden en is buitenpromovendus aan de Rijksuniversiteit Groningen. Feikje Vellinga-Schootstra is hoogleraar straf(proces)recht aan de Rijksuniversiteit Groningen en raadsheer-plaatsvervanger in Gerechtshof Arnhem-Leeuwarden. 
Daarbij gaat hij in op de verhouding tussen dit verschoningsrecht en de beroepsgeheimhoudingsplichten van deze beroepsgroepen.

In het tweede deel beschouwt Vellinga-Schootstra de beperkingen die het verschoningsrecht meebrengt bij de toepassing van de dwangmiddelen inbeslagneming en doorzoeking. Zij besteedt voorts aandacht aan de in de rechtspraak erkende mogelijkheden om in zeer uitzonderlijke gevallen het verschoningsrecht te doorbreken. Daarnaast bespreekt zij de mogelijkheden om de rechtmatigheid van de toepassing van deze dwangmiddelen in een beklagprocedure of tijdens de behandeling van een strafzaak ter terechtzitting ter discussie te stellen.

\section{Deel I}

\section{De grondslag van het professionele verschoningsrecht}

Artikel 2I8 Sv geeft geen opsomming van de (categorieën van) personen die gebruik kunnen maken van het in die bepaling bedoelde verschoningsrecht. De bepaling spreekt slechts van '[hen] die uit hoofde van hun stand, hun beroep of hun ambt tot geheimhouding verplicht zijn'. De wetgever heeft het aan de rechter gelaten invulling te geven aan deze open omschrijving. Naast de arts, advocaat en notaris - die in dit stuk centraal staan - is ook de geestelijk verzorger onder de omschrijving gebracht. Er wordt dan ook wel gesproken van het 'klassieke kwartet'.

Helemaal zuiver is dat niet. Het verschoningsrecht is ook wel toegekend aan juridisch medewerkers van een bureau voor rechtshulp, verplegers en enkele andere beroepsgroepen die nauwe verwantschap vertonen met de vier kernberoepen. ${ }^{\mathrm{I}}$ In de literatuur wordt daarom wel gesproken van vier beroepskringen of -sferen: juridische hulpverlening, (para)medische hulpverlening, notariaat en geestelijk-maatschappelijke hulpverlening. ${ }^{2}$

Met die aanduidingen wordt misschien meer ruimte gesuggereerd dan er daadwerkelijk is. Ruimhartig is de Hoge Raad namelijk niet. Toen een belastingadviseur aanspraak maakte op het verschoningsrecht, erkende de Hoge Raad dat ook belastingadviseurs als rechtshulpverleners kunnen worden aangemerkt. Het mocht deze beroepsgroep echter niet baten. De Raad wees op het uitzonderingskarakter van het verschoningsrecht en overwoog vervolgens dat aan andere rechtshulpverleners dan de advocaat en de notaris het verschoningsrecht in beginsel moet worden ontzegd. ${ }^{3}$

I Respectievelijk HR 5 oktober I986, NJ I986, I76 en HR 23 november I99I, NJ I99I, 76I. Wat betreft de laatste kring kunnen reclasseringsambtenaren (HR 20 juni I968, LJN AC4872, NJ I968, 332) en onderzoekers van de Raad voor de Kinderbescherming (HR 25 september 20I2, LJN BX4269, $\mathrm{NJ} 2013, \mathrm{I27}$ ) als voorbeelden worden genoemd.

2 F.J. Fernhout, Het verschoningsrecht van getuigen in civiele zaken (diss. Maastricht), Maastricht: Uitgeverij Gianni 2004, p. 225 e.v.

3 HR 6 mei ig86, NJ I986, 8I4, r.o. 4.3. Wel is in het belastingrecht aanvaard dat de belastingadviseur ten opzichte van de Belastingdienst aanspraak kan maken op een informeel verschoningsrecht: op grond van het fair play-beginsel kunnen stukken waarop jegens de belastingplichtige geen aanspraak kan worden gemaakt, ook niet via de belastingadviseur worden verkregen. 
Ook andere beroepen waarbij vertrouwelijkheid een grote rol speelt, zoals de registeraccountant en de mediator, deden tevergeefs een beroep op het verschoningsrecht. ${ }^{4}$

Volgens de Hoge Raad ziet artikel 2I8 Sv:

'op personen tot wier taak het behoort aan anderen hulp te verlenen doch die deze taak slechts dan naar behoren kunnen vervullen indien zij zich ook tegenover de strafrechter kunnen verschonen ten aanzien van geheimen welke hun zijn toevertrouwd door hulpzoekenden die - in strijd met het algemeen belang - hun geen hulp zouden vragen indien niet de zekerheid zou bestaan de evenbedoelde geheimen ook tegenover de strafrechter worden bewaard'.

Uit die omschrijving kan worden afgeleid dat een beroepsbeoefenaar aanspraak kan maken op het verschoningsrecht, als is voldaan aan twee vereisten. Enerzijds moet hij kunnen worden aangemerkt als vertrouwenspersoon. Aan zijn beroep moet onlosmakelijk een geheimhoudingsplicht zijn verbonden, in die zin dat het alleen goed kan worden uitgeoefend als volledige, ook door de staat te respecteren vertrouwelijkheid wordt geboden. Anderzijds moet met het beroep een in het algemeen belang noodzakelijke hulpverleningstaak worden behartigd.

Deze afbakening werd door de Hoge Raad al onder de werking van het oude Wetboek van Strafvordering van 1838 gehanteerd. ${ }^{6}$ De wetgever kon zich in de benadering van de Hoge Raad kennelijk vinden; het huidige artikel 218 Sv is nagenoeg letterlijk uit het oude wetboek overgenomen.

De nadruk ligt op het tweede vereiste. Daarin is immers de maatschappelijke rechtvaardiging van het verschoningsrecht te vinden. Of in de woorden van de Hoge Raad:

'De grondslag van dit verschoningsrecht moet worden gezocht in een in Nederland geldend algemeen rechtsbeginsel dat meebrengt dat bij zodanige vertrouwenspersonen het maatschappelijk belang dat de waarheid in rechte aan het licht komt, moet wijken voor het maatschappelijk belang dat een ieder zich vrijelijk en zonder vrees voor openbaarmaking van het besprokene om bijstand en advies tot hen moet kunnen wenden'?

Volgens Van Domburg ziet het verschoningsrecht op existentiële hulpverlening met een vertrouwelijk karakter. Ten aanzien van de notaris en advocaat - 'existentiële hulpverlening' laat zich bij de arts het gemakkelijkst voorstellen - bedoelt hij daarmee dat het moet gaan om zwaarwichtige hulp die noodzakelijk is om de juridische nood van de hulpzoekende te verhelpen. Zo kan de hulp van de advocaat noodzakelijk

4 HR 25 oktober I983, NJ I984, I32 en nadien in een civiele zaak HR I4 juni I985, NJ I986, I75 (registeraccountant) en HR Io april 2009, LJN BG9470, NJ 2010, 47I (mediator).

$5 \quad$ HR 25 oktober $\mathrm{I}_{983}, \mathrm{NJ}$ I984, I32.

6 HR 2I april I9I3, NJ I9I3, p. 958.

7 HR I maart I985, NJ I986, I73, r.o. 3.I. 
zijn om een verdachte ter terechtzitting te verdedigen, terwijl de hulp van een notaris onontbeerlijk is voor het rechtsgeldig laten opmaken van een testament. ${ }^{8}$

De benadering legt erg de nadruk op de noodzaak van de hulpverlening voor het individu. Zij spreekt mij daarom niet aan. Voor de vraag of een beroepsgroep voor het verschoningsrecht in aanmerking komt, is naar mijn oordeel veeleer doorslaggevend of de geboden hulpverlening voor het goed functioneren van de staat van wezenlijk belang is. ${ }^{9}$ Met andere woorden, of de hulpverlening voor de staat existentieel is.

In dit stuk staat centraal het verschoningsrecht dat is verbonden aan 'uit hoofde van stand, beroep of ambt' voortvloeiende verplichtingen tot geheimhouding van toevertrouwde informatie. Er wordt om die reden ook wel gesproken van het professioneel verschoningsrecht (hierna ook: het verschoningsrecht).

In het navolgende zal ik spreken van beroepsgroepen, beroepsgeheimhouders en beroepsgeheimhoudingsplicht. Daarbij doel ik telkens voor het gemak ook op (de geheimhoudingsplicht van) de notaris. Dat is wellicht niet helemaal zuiver. Anders dan de arts en advocaat is de notaris immers niet alleen beroepsuitoefenaar maar ook ambtenaar. Op zijn dubbele status ga ik nog uitgebreider in.

Naast het professionele verschoningsrecht bestaan in het strafprocesrecht nog enkele uitzonderingen op de doorgaans voor eenieder geldende getuigplicht.

In de rechtspraak is aanvaard dat ook ten aanzien van aan andere beroepen of maatschappelijke functies verbonden geheimhoudingsplichten een verschoningsrecht kan worden aangenomen, indien met het effectief kunnen uitoefenen van die beroepen of functies zwaarwegende maatschappelijke belangen zijn gemoeid, de gerede mogelijkheid bestaat dat die belangen worden geschaad indien geen geheimhoudingsplicht en verschoningsrecht wordt aangenomen en zulks vergt dat het 'aanzienlijke belang van een goede strafrechtspleging' wijkt. ${ }^{\text {I }}$

Ook kan een bepaling in bijzondere wetgeving aan de uitoefening van een beroep of maatschappelijke functie een geheimhoudingsplicht verbinden en kan in die bepaling soms een verschoningsrecht besloten liggen. ${ }^{\text {II }}$

Bovendien kent de wet verschoningsrecht voor sommige bloed- en aanverwanten van de verdachte of medeverdachte (artikel 2I7 Sv), voor degene die door het afleggen van een verklaring zichzelf of een nauwe verwant aan het gevaar van een

8 P.J.M. van Domburg, Over de grenzen van het verschoningsrecht, 's-Gravenhage: VUGA I994, p. 27.

9 Zo begrijp ik ook J.B.M. Vranken, Het professionele (functionele) verschoningsrecht (preadvies NJV), Zwolle: W.E.J. Tjeenk Willink i986, p. 66.

Io HR 25 oktober I983, NJ I984, I32, r.o. 5.7 en nadien HR I5 oktober I999, LJN AA3797, NJ 200I, 42, r.o. 3.4. Volgens G.J.M. Corstens (bewerkt door M.J. Borgers), Het Nederlands strafprocesrecht, Deventer: Kluwer 20II, p. I3I gaat het hier om een tweede - naast de hiervoor besproken - grondslag van het professionele verschoningsrecht/het verschoningsrecht van art. 2I8 Sv. Een meer algemeen geformuleerde grondslag die in feite de eerste grondslag omvat. Zie in die zin ook Vranken I986, p. 66.

II HR 22 december I989, NJ I990, 779, r.o. 3.2, doch slechts 'indien uit de bewoordingen, de strekking of de geschiedenis van de desbetreffende bepaling onmiskenbaar duidelijk blijkt dat de voor het aannemen van een dergelijk recht vereiste afweging door de wetgever is verricht'. 
strafrechtelijke veroordeling zou blootstellen (artikel 2I9 Sv) en voor bedreigde en afgeschermde getuigen (artikel 2rga Sv).

Tot slot kan de rechter nog terugvallen op zijn bevoegdheid om (ambtshalve of op vordering van de officier van justitie of op verzoek van de verdachte) te beletten dat door de getuige aan een gestelde vraag gevolg wordt gegeven (artikel 293 Sv).

\section{$3 \quad$ Maatschappelijk belang}

Artsen, advocaten en notarissen bieden een vorm van hulpverlening die in het algemeen belang noodzakelijk is. Traditioneel zijn zij op hun eigen terrein telkens de enige waartoe men zich voor deze hulpverlening kan wenden. Tegenwoordig is dat het min of meer logische gevolg van het hun toekomende domeinmonopolie. Door bepaalde werkzaamheden aan deze beroepsgroepen voor te behouden, heeft de wetgever bewerkstelligd dat toelatings- en opleidingseisen kunnen worden gesteld en de kwaliteit van de hulpverlening kan worden geborgd.

De advocaat vervult een essentiële rol in de rechtsbedeling. Hij heeft het procesmonopolie. Veel juridische procedures kunnen daarom slechts met de bijstand van een advocaat worden gevoerd. De notaris heeft een belangrijke ordenende functie in het civielrechtelijke rechtsverkeer. Zijn tussenkomst is verplicht voor de totstandkoming van een groot aantal rechtshandelingen. Hij is exclusief bevoegd tot het opmaken van bepaalde akten, zoals in geval van overdracht van onroerende zaken, het oprichten van een besloten vennootschap of het maken van huwelijksvoorwaarden en testamenten. Artsen waarborgen de volksgezondheid. Zij kennen de zogenoemde medische voorbehouden handelingen, zoals het uitvoeren van chirurgische en verloskundige handelingen en het voorschrijven van geneesmiddelen.

De werkzaamheden van artsen, advocaten en notarissen stekken zich evenwel niet strikt uit tot de werkzaamheden die onder dit monopolie vallen. Dat kan ook niet. De effectiviteit van de verleende bijstand zal vaak in belangrijke mate afhangen van advisering.

$\mathrm{Nu}$ dergelijk advieswerk niet onder het monopolie valt, kan het ook door andere beroepsgroepen worden verricht. Dat geldt ook voor andere werkzaamheden die van oudsher wellicht kunnen worden gezien als typisch artsen-, advocaten- en notarissenwerk maar niet onder het monopolie vallen.

Omgekeerd moeten de beoefenaren van deze 'vrije beroepen' zich steeds meer als ondernemers zien staande te houden. Dat geldt zeker voor de advocaat en notaris, maar ook in de zorg wordt de discussie over marktwerking gevoerd. Werkterreinen worden uitgebreid of verlegd. Toenemende specialisatie, schaalvergroting en samenwerking met andere beroepsgroepen makt het moeilijker de kern van het beroep te definiëren. De term 'beroepsgroep' lijkt dan ook aan erosie onderhevig. ${ }^{\text {I2 }}$

I2 Zie daarover ten aanzien van de juridische beroepen E. Niemeijer en M. ter Voert, 'Vertrouwen onder druk; vrije juridische beroepen tussen professie en commercie', Justitiële verkenningen 2005/03, Den Haag: Boom Juridische uitgevers, p. 26. 
Dat leidt enerzijds tot beroepsethische vragen. In hoeverre mogen financiële (eigen-)belangen ten koste gaan van de kwaliteit? Welke waarden zijn kenmerkend voor de beroepsuitoefening, en aan welke normen hebben beroepsuitoefenaars zich te houden? Anderzijds rijzen vragen naar de rechtvaardiging van het verschoningsrecht. Als het werkterrein wordt uitgebreid met of verlegd naar werkzaamheden die ook door andere beroepsgroepen worden verricht, of zouden kunnen worden verricht, is het dan aanvaardbaar dat artsen, advocaten en notarissen zich in het kader van die werkzaamheden op het verschoningsrecht kunnen beroepen en die andere beroepsgroepen niet?

Ook op meer abstract niveau spelen vragen naar de rechtvaardiging van de bijzondere positie van artsen, advocaten en notarissen en hun verschoningsrecht. Mensen zijn mondiger en beter geïnformeerd dan vroeger. Dat handelingen aan bepaalde beroepsgroepen zijn voorbehouden, wordt niet meer vanzelfsprekend geacht. Mensen stellen vragen bij de verplichte procesvertegenwoordiging van de advocaat en dokteren zelf met behulp van informatie en geneesmiddelen die zij op het internet vinden.

Bovendien lijkt minder maatschappelijk draagvlak te bestaan voor het uitgangspunt dat politie en justitie door de werking van het verschoningsrecht niet over bepaalde informatie kunnen beschikken. Gevallen waarin die mogelijkheid om informatie achter te houden, is misbruikt om strafbare feiten te verhullen, leiden dan ook niet zelden tot de oproep het verschoningsrecht dan maar helemaal af te schaffen.

In het navolgende wordt beschreven hoe het verschoningsrecht van artsen, advocaten en notarissen zich verhoudt tot de beroepsgeheimhoudingsplicht en welke grenzen de wetgever aan het verschoningsrecht heeft verbonden. Vervolgens wordt beschouwd hoe deze grenzen, mede in het licht van de hiervoor beschreven ontwikkelingen, in de rechtspraak en literatuur worden ingevuld. Eerst wijd ik echter enkele woorden aan de bijzondere positie van de notaris. In de literatuur wordt de vraag wel opgeworpen of deze beroepsgroep überhaupt aanspraak zou moeten kunnen maken op het verschoningsrecht.

\section{$4 \quad$ De notaris als vertrouwenspersoon?}

Dat de arts en advocaat aan hun status als vertrouwenspersoon het in artikel $218 \mathrm{~Sv}$ bedoelde verschoningsrecht kunnen ontlenen, is in de rechtspraak en literatuur onomstreden. Anders ligt dat bij de notaris. In de rechtspraak is hij weliswaar als verschoningsgerechtigde aangemerkt en is daarmee erkend dat de notaris meer is dan een officiële aktenverlijder en dat hij ook als vertrouwenspersoon een belangrijke rol vervult; in de literatuur worden bij zijn positie als verschoningsgerechtigde wel vragen gesteld.

Hiervoor werd al gewezen op de ordenende functie van de notaris in het rechtsverkeer en zijn bevoegdheid tot het verlijden van (exclusief aan de notaris voorbehouden 
alsook andere) authentieke akten. Verschillenden wetten belasten de notaris daarnaast nog met andere werkzaamheden, zoals onder meer het afgeven van afschriften, uittreksels en grossen, het legaliseren van handtekeningen en verschillende controletaken. ${ }^{13}$

In artikel 2 lid I Wet op het notarisambt (Wna) wordt verwezen naar de bevoegdheid tot het verlijden van akten en deze andere werkzaamheden. Er wordt dan ook wel gesproken van de 'wettelijke werkzaamheden' van de notaris. ${ }^{\text {I4 }}$

De wettelijke werkzaamheden oefent de notaris als ambtenaar uit op gezag van de overheid. Op grond van artikel I7 Wna is hij onafhankelijk en - in tegenstelling tot de advocaat - onpartijdig. De wet legt de notaris de plicht op partijen voorlichting te geven over de inhoud van de te verlijden akte en hen voor mogelijke (bezwarende) gevolgen te waarschuwen. Aangenomen wordt dat deze informatie- en waarschuwingsplicht niet is beperkt tot de werkzaamheden met betrekking tot akten, maar steeds geldt als de notaris wettelijke werkzaamheden verricht. ${ }^{15}$

Met het voorgaande is het werkterrein van de notaris niet uitputtend beschreven. De notaris verricht ook een groot aantal buitenwettelijke (ook wel: niet ambtelijke) werkzaamheden, zoals het geven van (niet met een notariële akte of ander aan de notaris opgedragen werkzaamheid samenhangend) juridisch advies of het opmaken van onderhandse akten. Deze werkzaamheden verricht de notaris niet als ambtenaar.

De bepalingen in de Wna over onafhankelijkheid en de ministerieplicht (artikel 2I Wna) zijn op de buitenwettelijke werkzaamheden niet van toepassing. Niet alle bepalingen uit de Wna zijn echter tot de wettelijke werkzaamheden van de notaris beperkt. De regels over tuchtrecht en financiële controle zien op het handelen van de notaris 'als zodanig'. Ook de in artikel 22 Wna opgenomen geheimhoudingsplicht strekt zich uit 'ten aanzien van al hetgeen waarvan hij uit hoofde van zijn werkzaamheid als zodanig kennis neemt'. ${ }^{16}$ Volgens de Commissie Evaluatie Wet op het notarisambt - die in 2005 op verzoek van de minister van Justitie een evaluatie uitvoerde van de in 1999 in werking getreden wet - wordt daarmee recht gedaan aan het feit dat een onderscheid tussen beide soorten werkzaamheden door de notaris niet steeds strikt is te maken en de omstandigheid dat een dergelijk onderscheid door cliënten niet wordt verwacht. De notaris heeft een breed aanvaarde positie als publiek vertrouwenspersoon ten aanzien van al zijn werkzaamheden. ${ }^{17}$

I3 Zie voor een uitgebreider overzicht J.C.H. Melis (bewerkt door B.C.M. Waaijer), De Notariswet, Deventer: Kluwer 20I2, p. I2-I3.

I4 De notaris pleegt - in de bewoordingen van art. I6 Wna-daarnaast nog enkele werkzaamheden te verrichten die in nauw verband staan met de wettelijke werkzaamheden, zoals het doorbetalen van de kooppenningen aan de verkoper in geval van overdracht van een woning.

I5 Art. 43 Wna. Zie Melis/Waaijer 20I2, p. 22.

I6 Op de naam van de wet, waarin immers het woord 'ambt' wordt gebezigd, is dan ook kritiek. Vgl. B.C.M. Waaijer, 'Een nieuwe Wet op het notarisambt of een nieuwe Notariswet: What's in a name?', WPNR I999/6363, p. 485.

I7 Rapport van de Commissie Evaluatie Wet op het notarisambt (commissie-Hammerstein), Het beste van twee werelden, 2005 , p. I6. 
Volgens Fernhout is de positie van de notaris als publiek vertrouwenspersoon onvoldoende om daarop het in artikel 2I8 Sv bedoelde verschoningsrecht voor vertrouwenspersonen te baseren. Het mag zo zijn dat uit de begeleidingstaak bij het opstellen van akten een praktijk is ontstaan waarin de notaris is uitgegroeid tot adviseur in 'alle zaken waaraan een juridisch aspect kleeft', daarin ligt volgens Fernhout echter geen rechtvaardiging voor het (nog langer handhaven van het) verschoningsrecht van de notaris. Juridische hulpverlening kan worden verleend door (de beroepskring van) advocaten. Hun verschoningsrecht vindt zijn rechtvaardiging in het maatschappelijk belang dat rechtzoekenden zich tot hen kunnen wenden voor bijstand en advies. Het algemeen belang vergt (dus) niet dat ook notarissen zich op dat terrein begeven.

Volgens Fernhout zou het verschoningsrecht van notarissen niet uit hun status van vertrouwenspersoon moeten worden afgeleid, maar (wettelijk) gekoppeld moeten worden aan een wettelijke verplichting tot geheimhouding van de inhoud van akten. ${ }^{18}$ Er zijn immers wel meer beroepsgroepen die niet de status van vertrouwenspersoon hebben, maar aan wie wel een (wettelijk) verschoningsrecht toekomt. ${ }^{\text {I9 }}$

Ik deel de opvatting van Fernhout niet. Zij doet weinig recht aan de omstandigheid dat achter de totstandkoming van een akte, of achter de beslissing geen akte te laten opstellen, gevoelige overwegingen en motieven schuil kunnen gaan en dat het niet kunnen waarborgen van de vertrouwelijkheid daarvan familierelaties en zakelijke betrekkingen ernstig onder druk kan zetten en een belemmering kan vormen om vrijuit met de notaris te spreken. Juist in zijn rol van onafhankelijk adviseur heeft de notaris een belangrijke maatschappelijke meerwaarde. ${ }^{20}$ Indien de notaris niet kan beschikken over alle relevante informatie, kan hij onvoldoende invulling geven aan zijn voorlichtings- en waarschuwingsplicht. ${ }^{2 \mathrm{I}}$

Nu zou de door Fernhout voorgestane wettelijke geheimhoudingsplicht natuurlijk een ruimere strekking kunnen krijgen dan slechts de verplichting tot geheimhouding van de inhoud van aktes. Zij zou, ter bescherming van de vertrouwensrelatie tussen notaris en cliënt, mede betrekking kunnen hebben op hetgeen wordt toevertrouwd in het kader van (met een notariële akte of andere aan de notaris bij wet opgedragen werkzaamheid samenhangende) adviserende werkzaamheden. Het resultaat is dan wellicht dat het in artikel $2 \mathrm{I} 8 \mathrm{~Sv}$ bedoelde verschoningsrecht van vertrouwenspersonen niet langer van toepassing is. Maar is dat niet slechts een vorm van Etikettenschwindel?

\section{I8 Fernhout 2004, p. 235.}

I9 Denk bijvoorbeeld aan ambtenaren van de Algemene Inlichtingen- en Veiligheidsdienst (art. 85 en 86 Wet op de inlichtingen- en veiligheidsdiensten 2002). Zie ook hetgeen hiervoor in paragraaf 2 over andere verschoningsrechten is opgemerkt.

20 Rapport van de Commissie Evaluatie Wet op het notarisambt, p. I4.

2I Vgl. ook C.A. Kraan, 'Geheimhoudingsplicht en verschoningsrecht van de notaris', in: Meer spreken, minder zwijgen (preadvies Koninklijke Notariële Beroepsorganisatie), Den Haag: Sdu Uitgevers 2007, p. 96. 


\section{Geheimhoudingsplichten en verschoningsrecht}

Aan het beroep van arts, advocaat en notaris is inherent een beroepsgeheimhoudingsplicht verbonden. Deze beroepen kunnen slechts dan goed worden beoefend wanneer de vertrouwelijkheid van hetgeen hun in het kader van de beroepsuitoefening wordt toevertrouwd, wordt gegarandeerd. Die verplichting heeft dus geen wettelijke basis. Zij kan tot uiting komen in een beroepseed of in gedragsregels.

Artikel 2 I8 Sv biedt artsen, advocaten en notarissen de gelegenheid hun beroepsgeheimhoudingsplicht tot op zekere hoogte ook ten overstaan van de rechter en dus ten koste van de waarheidsvinding in acht te nemen. De bepaling kan in die zin worden gezien als een wettelijke erkenning van deze plichten. Artikel $218 \mathrm{~Sv}$ is facultatief geformuleerd en houdt dus geen zwijgplicht in.

\section{'Artikel 218}

Van het geven van getuigenis of van het beantwoorden van bepaalde vragen kunnen zich ook verschoonen zij die uit hoofde van hun stand, hun beroep of hun ambt tot geheimhouding verplicht zijn, doch alleen omtrent hetgeen waarvan de wetenschap aan hen als zoodanig is toevertrouwd.'

Ook artikel 272 Wetboek van Strafrecht (Sr) heeft het oog op (onder meer) deze ongeschreven beroepsgeheimhoudingsplichten. Het schrijft de naleving van de plichten dwingend voor.

\section{'Artikel 272}

1. Hij die enig geheim waarvan hij weet of redelijkerwijs moet vermoeden dat hij uit hoofde van ambt, beroep of wettelijk voorschrift dan wel van vroeger ambt of beroep verplicht is het te bewaren, opzettelijk schendt, wordt gestraft met gevangenisstraf van ten hoogste een jaar of geldboete van de vierde categorie.

(...)

Beide bepalingen zien dus (deels) op dezelfde geheimhoudingsplichten en staan op die manier indirect met elkaar in verband. Een direct verband ontbreekt. ${ }^{22}$

In de literatuur is uitgebreid gediscussieerd over de vraag of het afleggen van getuigenverklaringen door artsen, advocaten en notarissen leidt tot strafbaarheid op grond van artikel $272 \mathrm{Sr}^{23}$

Veelal wordt daarbij miskend dat in het Wetboek van Strafrecht uitdrukkelijk niet is beoogd straf te stellen op het afleggen van getuigenverklaringen of het voldoen aan andere strafvorderlijke dwangmiddelen, zoals bijvoorbeeld door het opvolgen van een bevel om voorwerpen ter inbeslagneming uit te leveren. De bepaling stelt alleen het openbaren van beroepsgeheimen buiten de rechtszaal strafbaar. Het

22 Vgl. Fernhout 2004, p. I75-I77, zij het op (deels) andere gronden. Zijn standpunt dat (de formulering van) het verschoningsrecht in het wetboek van 1838 verband houdt met de strafbaarstelling uit art. 378 van de uit de Franse tijd geërfde Code pénal deel ik niet.

23 Voor een overzicht: zie A.L. Melai, M.S. Groenhuijsen e.a., Het Wetboek van Strafvordering, Deventer: Kluwer (losbl.), aant. 8 bij art. 2 I8 Sv (bijgewerkt door T.N.B.M. Spronken en F.J. Fernhout tot I februari 2004). 
bijdragen aan de strafrechtelijke waarheidsvinding wordt door het wetboek gezien als een belangrijke burgerplicht. Ook het niet-naleven van de spreekplicht als getuige is in het wetboek strafbaar gesteld en wordt in strafzaken met een hogere straf bedreigd dan in andere zaken (artikel $192 \mathrm{Sr}$ ). De spreekplicht wordt in beginsel van een hogere orde geacht dan de verplichting een ambt- of beroepsgeheim in acht te nemen. ${ }^{24}$

Bij de totstandkoming van artikel $272 \mathrm{Sr}$ werd door de wetgever vooropgesteld dat het niet de bedoeling was straf te stellen op het afleggen van getuigenverklaringen door verschoningsgerechtigde beroepsgeheimhouders als artsen, advocaten en notarissen. Dat is niet in de tekst van artikel $272 \mathrm{Sr}$ tot uitdrukking gebracht, maar werd geacht reeds voort te vloeien uit het stelsel van (het ontwerp van) de wet. Dat stelsel gaat immers ervan uit dat bij botsing van wettelijke plichten niet strafbaar is degene die een plicht of plichten schendt om aan de zwaarstwegende plicht te voldoen. Iemand die voldoet aan de getuigplicht komt, met andere woorden, een beroep toe op de rechtvaardigingsgrond van het huidige artikel $42 \mathrm{Sr}$.

Verschillende auteurs hebben betoogd dat deze redenering ondeugdelijk is. Zij leiden uit het feit dat het verschoningsrecht als een bevoegdheid is geformuleerd af, dat de verschoningsgerechtigde 'kan' kiezen om geen verklaring als getuige af te leggen. Voor hem bestaat dus geen plicht om te getuigen en is dus geen sprake van botsing van wettelijke plichten. Volgens deze auteurs leidt het afleggen van een getuigenverklaring dan ook tot strafbaarheid, tenzij sprake is van een (door de wet erkende) overmachtsituatie. ${ }^{25}$

Die redenering is door de wetgever echter uitdrukkelijk van de hand gewezen. Dat de beroepsgeheimhouder mag zwijgen, ontneemt hem niet het recht om te spreken. Ook hij handelt in dat geval 'ter uitvoering van een wettelijk voorschrift' en is dus mede gedekt door artikel $42 \mathrm{Sr}^{26}$

Uit deze wetsgeschiedenis en de rechtspraak van de Hoge Raad leid ik af dat de wetgever de vertrouwensrelatie tussen verschoningsgerechtigde beroepsbeoefenaars en hun cliënten heeft willen respecteren, in die zin dat deze beroepsbeoefenaars niet tot het afleggen van getuigenverklaringen gedwongen moeten kunnen worden. Het veel gehoorde standpunt dat de wetgever heeft gemeend dat de geheimhoudingsplichten zwaarder wegen dan de waarheidsvinding in rechte, deel ik dan ook niet. De beroepsgeheimhouder kan ervoor kiezen een verklaring af te leggen of onder zijn verschoningsrecht vallende stukken in het kader van inbeslagneming aan justitie te verstrekken. Wordt de informatie verstrekt, dan kan deze gewoon voor het bewijs worden gebezigd. Evenmin leid ik uit de rechtspraak van de Hoge Raad over de 'zeer uitzonderlijke omstandigheden' af dat de Hoge Raad van oordeel is dat

24 Zie in die zin ook T.J. Noyon, G.E. Langemeijer en J. Remmelink (red.), Het Wetboek van Strafrecht, Deventer: Kluwer 20I0, aant. 2 bij art. 272 Sr (bijgewerkt door A.J. Machielse tot I juli 2006).

25 Zie onder meer D. Hazewinkel-Suringa, De doolhofvan het beroepsgeheim, Haarlem: H.D. TjeenkWillink \& Zoon 1959, p. I67; J.J.I. Verburg, Het verschoningsrecht van getuigen in strafzaken, Groningen: H.D. Tjeenk Willink I975, p. 279-28I en J.C.M. Leijten, 'Het professionele (of functionele) verschoningsrecht', NJB I986, p. 708.

Kamerstukken II I878/79, IIo, nr. 3, p. II3 (MvT). 
een verschoningsgerechtigde zijn beroepsgeheim slechts in die omstandigheden mag doorbreken, zoals door sommige auteurs wordt betoogd. Die rechtspraak ziet immers op het doorbreken van het verschoningsrecht en niet op doorbreking van het beroepsgeheim. ${ }^{27}$

Dit uitgangspunt brengt in beginsel - en daar wijzen de eerder aangehaalde auteurs terecht op - mee dat cliënten niet zeker weten of hun arts, advocaat of notaris vertrouwelijkheid steeds zwaarder zal laten wegen dan de waarheidsvinding. In beginsel, want helemaal waar is dat niet. Dat spreken vanuit strafrechtelijk oogpunt geen consequenties heeft, betekent uiteraard niet dat de beroepsgeheimhoudingsplicht doorgaans niet aan spreken in de weg zal staan. Het schenden van die plicht kan wel degelijk leiden tot tucht- en civielrechtelijke aansprakelijkheid.

Het uitgangspunt spreekt mij overigens nog steeds aan. Dat neemt niet weg dat de wetgever naar mijn oordeel recente wetgevingsactiviteiten had moeten aangrijpen om de praktijk meer sturing te geven. Kwesties rond het beroepsgeheim worden tegenwoordig immers niet meer alleen vanuit het oogpunt van vertrouwensrelaties bekeken. Gegevens die onder het verschoningsrecht vallen, raken veelal ook aan de persoonlijke levenssfeer. Sinds de totstandkoming van de wettelijke vastlegging van het verschoningsrecht en de invoering van de besproken strafbaarstelling is er veel meer aandacht gekomen voor privacyrechten. De wetgever heeft artsen en notarissen relatief recentelijk ook een wettelijke geheimhoudingsplicht opgelegd. ${ }^{28}$ Momenteel is een voorstel tot herziening van de Advocatenwet aanhangig, waarin in het opnemen van een wettelijke geheimhoudingsplicht voor advocaten wordt voorzien. ${ }^{29}$ Het is een gemiste kans dat de wetgever de totstandkoming van deze regelingen niet heeft laten voorafgaan door een fundamentele herbezinning op de verhouding tussen geheimhoudingsplichten en de waarheidsvinding.

\section{De reikwijdte van het verschoningsrecht}

Het verschoningsrecht is niet gekoppeld aan een wettelijke geheimhoudingsplicht. Het biedt de arts, advocaat en notaris de gelegenheid de aan hun beroep verbonden geheimhoudingsplicht ook ten overstaan van de rechter in acht te nemen. Bij het uitgangspunt dat het verschoningsrecht niet afhankelijk is van een bij wet afgebakende geheimhoudingsplicht past dat de wetgever het verschoningsrecht in artikel 2I8 Sv een eigen afgrenzing heeft gegeven. In een arrest uit 2010 overwoog de Hoge Raad over de reikwijdte van het verschoningsrecht:

27 Vgl. onder meer Van Domburg 1994, p. 95.

28 Voor artsen is in 1995 art. 88 Wet op de beroepen in de individuele gezondheidszorg (Wet BIG) ingevoerd en vloeit tevens een geheimhoudingsplicht voort uit de in datzelfde jaar tot stand gekomen wettelijke kaders voor de (privaatrechtelijke) behandelovereenkomst (art. 7:457 Burgerlijk Wetboek (BW)). Voor notarissen trad in 1999 art. 22 Wna in werking. 
'Ingevolge art. $218 \mathrm{~Sv}$ kan een advocaat zich in rechte op zijn verschoningsrecht beroepen, doch alleen omtrent hetgeen waarvan de wetenschap aan hem als zodanig is toevertrouwd. Dat houdt in dat een advocaat zich slechts op zijn verschoningsrecht kan beroepen met betrekking tot de wetenschap die hij in de normale uitoefening van zijn beroep heeft verkregen.'

De term 'normale beroepsuitoefening' werd in de literatuur al eerder gebruikt. ${ }^{30}$ Andere auteurs drukken naar mijn oordeel hetzelfde uit door te stellen dat tussen wetenschap en werkzaamheden een 'functioneel verband' moet bestaan. ${ }^{3 \text { ' }}$

Bij de interpretatie van de reikwijdte wordt logischerwijze teruggegrepen op de grondslag van het verschoningsrecht. Dat kan betekenen dat ook in gevallen waarin zou kunnen worden aangenomen dat de geheimhoudingsplicht niet meer bestaat, zoals wanneer de hulpzoekende de beroepsgeheimhouder uit de geheimhoudingsplicht heeft ontslagen, toch een beroep op het verschoningsrecht kan worden gedaan. Omgekeerd kan uit die grondslag voortvloeien dat het verschoningsrecht aan scherpere grenzen is gebonden dan de beroepsgeheimhoudingsplicht.

\section{I Toestemming tot openbaren}

Een belangrijke gevolgtrekking die de Hoge Raad heeft ontleend aan het uitgangspunt dat het verschoningsrecht zijn grondslag vindt in het eerder beschreven algemene maatschappelijke belang (en niet in het individuele belang van degenen die van zijn hulp gebruikmaken) is dat toestemming tot openbaring van de direct belanghebbenden niet leidt tot opheffing van het verschoningsrecht. ${ }^{32}$ Toestemming leidt, met andere woorden, niet tot een spreekplicht. Zij dient door de verschoningsgerechtigde wel te worden betrokken in zijn afweging of een beroep op het verschoningsrecht wordt gedaan. ${ }^{33}$

De Hoge Raad heeft dit wel onderbouwd met de overweging dat een andere opvatting ertoe zou leiden dat:

'het oordeel omtrent de geloofwaardigheid van hen die zich tot de betreffende vertrouwenspersoon hebben gewend, ongunstig zou kunnen worden beïnvloed door hun weigering hem uit zijn geheimhoudingsplicht te ontslaan, zodat de vrees dat zij daardoor naderhand tot een zodanig ontslag

30 Ook T.N.B.M. Spronken, 'Verschoningsrecht', in: T. Prakken en T.N.B.M. Spronken (red.), Handboek verdediging, Deventer: Kluwer 2009, p. Iog en Van Domburg 1994, p. 29-30 spreken van 'normale beroepsuitoefening'. Van Domburg vertaalt dat ook naar 'zuiver functioneel verband'.

3I G.E. Langemeijer, 'Het medisch beroepsgeheim', Tijdschrift voor Strafrecht I956, p. 3: de zwijgplicht van de dokter omvat 'alles wat men enkel ten gevolge van zijn werkzaamheid als arts niet voor hem heeft kunnen of willen verbergen' en Verburg 1975, p. 6I: 'een functioneel verband (...), d.w.z. er moet een duidelijke relatie zijn tussen de informatie waarvoor betrokkene zich wil verschonen en de werkzaamheden, die als grondslag voor zijn erkenning als subject van verschoning hebben gediend'. Eerder (p. 57) spreekt hij ook van 'normale uitoefening van zijn werkzaamheden'.

32 HR 2 oktober I990, LJN AB8I07, NJ I99I, I24, r.o. 6.2.

33 HR 26 mei 2009, LJN BG5979, NJ 2009, 263, r.o. 2.6.3. 
zouden worden genoopt hen ervan zou kunnen weerhouden de hulp van die vertrouwenspersoon in te roepen of zich vrijelijk tegenover hem uit te spreken.' 34

Volgens Leijten is die redenering erg ver gezocht. Dat iemand aanspraak maakt op geheimhouding en de verschoningsgerechtigde niet van zijn geheimhoudingsplicht ontslaat, is volgens hem immers het uitgangspunt. Het verbinden van ongunstige gevolgen aan een gewone situatie zou getuigen van slecht rechterlijk optreden. Ook Leijten meent evenwel dat ontslag uit de geheimhoudingsplicht niet leidt tot een verplichting om te spreken. In de vaststelling dat het verschoningsrecht een algemeen belang dient, ligt naar zijn oordeel besloten dat daarmee ook het belang van het individu in het concrete geval wordt gediend. Ontslag uit de geheimhoudingsplicht houdt (niet meer) in (dan) dat naar het oordeel van de cliënt dat laatste belang zwijgen niet meer vereist. ${ }^{35}$

Vranken heeft zich afgevraagd of de benadering van de Hoge Raad niet wat 'aanmatigend en paternalistisch' en strijdig met de tijdgeest is. Hij heeft bepleit, in navolging van de common law- landen, het verschoningsrecht als een recht van de cliënt aan te merken. Het verschoningsrecht dient weliswaar het algemene maatschappelijke belang van vertrouwelijke gedachtewisseling, maar dat belang wordt volgens hem niet aangetast indien de cliënt achteraf aangeeft op vertrouwelijkheid geen prijs meer te stellen. ${ }^{36}$ Veel bijval heeft het pleidooi van Vranken niet gekregen. ${ }^{37}$ De algemene teneur in de literatuur was en is toch dat de vertrouwenspersoon nu eenmaal de deskundigheid en afstand heeft om - zowel in het belang van de desbetreffende cliënt als in het belang dat gegarandeerd blijft dat ook anderen vrijelijk hulp durven inschakelen - te beoordelen of moet worden gezwegen. ${ }^{38}$

\subsection{Toevertrouwde wetenschap}

Blijkens artikel 2I8 Sv is het verschoningsrecht beperkt tot de wetenschap die aan de verschoningsgerechtigde is 'toevertrouwd'. De algemene opvatting in rechtspraak en literatuur is dat deze term ruim moet worden uitgelegd. Het verschoningsrecht is niet beperkt tot de mededelingen die de cliënt aan de verschoningsgerechtigde

34 HR I maart I985, NJ I986, I73, r.o. 3.3. 't Hart spreekt in zijn noot NJ I99I, I24 van een 'silence signatif' en wijst erop dat indien de arts gewoonlijk spreekt wanneer dat in het voordeel is van de patiënt en deze laatste toestemming heeft verleend, zwijgen in andere gevallen dan gemakkelijk zal kunnen worden uitgelegd in het nadeel van de betreffende patiënten. De verschoningsgerechtigde moet zich daarom ook met het oog op de belangen van andere (toekomstige) hulpzoekenden terughoudend opstellen.

35 Leijten I986, p. 708.

36 Vranken i986, p. 97 e.v.

37 R.H. de Bock, Tussen waarheid en onzekerheid: over het vaststellen van feiten in de civiele procedure (diss. Tilburg), Deventer: Kluwer 20II, p. I76 ziet bij toestemming geen zwaarwegend belang meer bij uitoefening van het verschoningsrecht. Haar beschouwingen zien echter slechts op civiele procedures waarbij de vraag speelt of de wetenschap ook jegens de betrokken partijen als aan de verschoningsgerechtigde toevertrouwd heeft te gelden. In de rechtspraak worden voor die gevallen reeds uitzonderingen gehanteerd (zie hierna).

38 Hazewinkel-Suringa I959, p. I45 e.v.; Verburg I975, p. 283; Van Domburg I994, p. 39, Fernhout 2004, p. I93 en Kraan 2007, p. I02. 
heeft gedaan. Het kan betrekking hebben op alle informatie die de verschoningsgerechtigde in het kader van zijn beroepsuitoefening verkrijgt. Die informatie kan ook van derden afkomstig zijn en behoeft niet speciaal voor de verschoningsgerechtigde te zijn opgesteld. ${ }^{39}$ Het verschoningsrecht kan voorts zien op hetgeen de verschoningsgerechtigde door zijn eigen onderzoek te weten komt. ${ }^{\circ}$ Ook hetgeen de verschoningsgerechtigde zelf heeft gezegd, verricht of geadviseerd kan onder het verschoningsrecht vallen. ${ }^{4 \mathrm{I}}$

In de literatuur wordt vrij algemeen aangenomen dat niet relevant is of het ook de bedoeling van de hulpzoekende was om de informatie te verstrekken. Een terloopse opmerking van de hulpzoekende waarvan deze de draagwijdte niet beseft kan immers relevant zijn. ${ }^{42}$ Ook de vermoeide indruk die een patiënt maakt, kan voor de arts waardevolle informatie zijn. Evenmin is van belang of het de intentie van de verschoningsgerechtigde was om de verkregen informatie te ontvangen. Vranken stelt in dat verband dat de onderscheidingen tussen 'horen, zien, begrijpen, afleiden, ondervinden, toevalligheden of het al dan niet gewild zijn van gegevens' zo verfijnd zijn, dat duidelijkheid hier de voorkeur verdient boven nuance. ${ }^{43}$

Die benadering spreekt aan. Het heeft immers een zekere onvermijdelijkheid dat de verschoningsgerechtigde meer te weten komt dan voor de hulpverlening strikt noodzakelijk is. Bovendien zullen hulpzoekenden niet steeds weten welke gegevens precies relevant zijn. Het is juist om die reden dat zij zich tot een deskundige hulpverlener wenden. Goede hulpverlening is pas mogelijk wanneer mensen vrijuit kunnen spreken. De Hoge Raad heeft in dat verband wel overwogen dat alles waarvan de wetenschap de verschoningsgerechtigde als zodanig is medegedeeld ook als hem toevertrouwd heeft te gelden, en dat daarbij geen plaats is voor een onderscheid tussen vertrouwelijke en minder vertrouwelijke gegevens. ${ }^{44}$

Spronken leidt uit het laatste gedeelte van deze overweging af dat alle verkregen wetenschap steeds onder het verschoningsrecht valt. ${ }^{45}$ Daarmee ziet zij volgens mij over het hoofd dat de overweging slechts het oog heeft op mededelingen van de cliënt aan de verschoningsgerechtigde. Niet alleen vraag ik mij af of in de rechtspraak hetzelfde zou worden aangenomen ten aanzien van andere gegevens, zoals bijvoorbeeld mededelingen van derden, ik betwijfel bovendien of ook ten aanzien van mededelingen van de cliënt een dergelijke algemene regel wordt gesteld. ${ }^{6}$

HR 24 januari 2006, LJN AU4666, NJ 2006, I09, waar het dagboek van de moeder van een minderjarige verdachte in beslag was genomen.

40 HR 2 I april I9I3, NJ I9I3, p. 958.

4I HR 20 juni I968, NJ I968, 332. Vgl. in die zin ook HR I2 februari 2002, LJN AD4402, NJ 2002, 440, ten aanzien van de vraag of een door een registeraccountant aan een advocaat verstrekt advies ook onder diens (van dat van de advocaat) afgeleide verschoningsrecht valt.

42 Verburg 1975 , p. 65.

43 Vranken I986, p. II7. Vgl. ook Verburg I975, p. 56 die stelt dat ieder zintuig een rol mag spelen.

44 HR I maart I985, NJ I986, I73, r.o. 3.4 en HR I8 december I998, LJN ZC2808, NJ 2000, 34I, r.o. $3 \cdot 5 \cdot 2$.

45 Spronken 2009, p. II2.

46 Het gaat hier overigens om een overweging van de civiele kamer van de Hoge Raad. De 'regel' werd nadien al snel tot uitgangspunt genuanceerd: 'hetgeen hem als notaris is medegedeeld, 
In de rechtspraak wordt het antwoord op de vraag of sprake is van toevertrouwde wetenschap namelijk afhankelijk gesteld van de beoordeling of met het niet respecteren van de vertrouwelijkheid wordt getreden in de vertrouwensrelatie tussen hulpzoekende en verschoningsgerechtigde. Over het verschoningsrecht van een verpleger overwoog de Hoge Raad in een arrest uit I99I:

'Aangenomen moet (...) worden dat het verschoningsrecht van de verpleger zich niet alleen uitstrekt tot feiten die betrekking hebben op de behandeling en de verzorging van de aan zijn zorgen toevertrouwde patiënten, maar ook tot feiten die hem in zijn hoedanigheid zijn medegedeeld of waarvan hij in zijn hoedanigheid heeft kennis gekregen, en waarvan de openbaarmaking het vertrouwen zou beschamen dat de patiënten met het oog op zijn hulpverlenende taak in hem moeten kunnen stellen. Aan deze eis zal in het bijzonder zijn voldaan, wanneer het gaat om feiten die de persoonlijke levenssfeer van de aan hem toevertrouwde patiënten betreffen (...).'47

Uit die overweging begrijp ik, dat er volgens de Hoge Raad wel degelijk sprake kan zijn van minder vertrouwelijke gegevens, althans van niet-vertrouwelijke gegevens. Namelijk die gegevens die niet de vertrouwensrelatie tussen verschoningsgerechtigde en cliënt schaden. Zelfs de omstandigheid dat het gaat om gegevens die de persoonlijke levenssfeer betreffen, brengt volgens de Hoge Raad niet zonder meer mee dat het gaat om 'toevertrouwde wetenschap'. Volgens de Hoge Raad zal bij het openbaar moeten maken van dergelijke gegevens immers 'in het bijzonder' kunnen worden aangenomen dat de vertrouwensrelatie wordt geschaad, maar kennelijk is dat naar zijn oordeel niet steeds het geval..$^{8}$

Met deze benadering maakt de Hoge Raad het nogal ingewikkeld. Hoe moet de afweging immers worden gemaakt indien slechts wordt gevraagd naar het bestaan van een hulpverleningsrelatie of om het verstrekken van naam- of adresgegevens van een patiënt of cliënt (waaruit de hulpverleningsrelatie indirect kan worden afgeleid)? Moet ook dan worden beoordeeld of de vertrouwensrelatie door de verstrekking van die gegevens wordt geschaad?

Vranken trekt de lijn van de Hoge Raad consequent door. Hij stelt voorop dat dergelijke gegevens in het algemeen geen aanleiding geven tot het verschoningsrecht.

[heeft] in beginsel ook als hem toevertrouwd (...) te gelden' (HR 25 september I992, LJN ZCo69o, NJ I993, 467, r.o. 3.2). Juist in de civielrechtelijke jurisprudentie worden met enige regelmaat uitzonderingen aanvaard op dit uitgangspunt. Indien partijen in het bijzijn van een notaris of advocaat onderhandelingen hebben gevoerd en tot overeenstemming zijn gekomen, wordt aangenomen dat hetgeen tijdens de onderhandelingen is besproken in een later geschil tussen die partijen niet ook jegens die partijen - die immers aanwezig waren - als aan de verschoningsgerechtigde is toevertrouwd heeft te gelden. Aangezien het hier gaat om geschillen tussen partijen en belanghebbende derden lijken deze uitzonderingen voor het strafrecht niet van belang.

47 HR 23 november I99I, NJ I99I, 76I, r.o. 3.3.

48 Ook Vranken meent dat de omstandigheid dat het gaat om gegevens die raken aan de persoonlijke levenssfeer niet vanzelfsprekend meebrengt dat met het verstrekken daarvan de vertrouwensrelatie geweld wordt aangedaan. Vgl. zijn noot onder HR 23 november I99I, NJ I99I, 76r. 
Dat zou volgens hem echter anders kunnen zijn, als de vertrouwelijkheid mede deze aspecten omvat. Bijvoorbeeld indien een advocaat een (anonieme) kraker bijstaat. ${ }^{49}$

Ook advocaat-generaal Machielse koos deze benadering in zijn conclusie voor HR 29 juni 2004, LJN AO5070, NJ 2005, 273. Het enkele feit dat iemand patiënt is van een arts acht hij niet zonder meer een gegeven dat de arts in zijn vertrouwensrelatie met de patiënt is bekend geworden. In die zaak ging het om de inbeslagneming van naam- en adresgegevens onder een jeugdpsychiatrische kliniek in verband met de verdenking van seksueel misbruik van twee patiënten door twee ex-patiënten en speelde de vraag of die gegevens onder het verschoningsrecht van de behandelend artsen vielen. Volgens Machielse was dat niet het geval. Daarbij gaf voor hem de doorslag dat het verband tussen het strafbare feit en de hulpvraag ontbrak, zodat de beslissing om hulp te vragen niet onder druk was gezet door de vrees dat de hulpverlener medewerking zou verlenen aan een onderzoek naar strafbare feiten. Volgens Machielse zou dat anders zijn, indien bijvoorbeeld iemand zich in het ziekenhuis meldt met verwondingen die zijn opgelopen tijdens een door hem gepleegde overval.

In de benadering van Vranken en Machielse kan ik mij niet vinden. Of de vertrouwensrelatie wordt geschaad, zal naar mijn mening moeten worden beoordeeld vanuit het perspectief van de hulpverleningsrelatie en niet vanuit het perspectief van de (straf)zaak waarin de gegevens worden gevraagd. Of een verband bestaat tussen de hulpvraag en het strafbare feit waarop het onderzoek zich richt, is naar mijn oordeel dan ook niet relevant voor de vraag of sprake is van 'toevertrouwde wetenschap'.

Ook Machielse lijkt de door hem gevolgde benadering overigens te beperkt te vinden. Eerder had hij namelijk al opgemerkt dat het enkele feit dat iemand een therapeut bezoekt die alleen 'seksuele aberraties' behandelt wel een toevertrouwd gegeven zou kunnen zijn..$^{\circ}$ Moet zijn conclusie dan zo worden begrepen dat naar zijn oordeel de wetenschap dat iemand een afspraak heeft met een therapeut voor seksuele aandoeningen van meer vertrouwelijke aard is dan de wetenschap dat iemand is opgenomen geweest in een kliniek voor jeugdpsychiatrie?5

De Hoge Raad volgde de advocaat-generaal niet. Uit de uitspraak kan worden afgeleid dat het enkele gegeven dat een persoon opgenomen is geweest in een jeugdpsychiatrische kliniek onder het verschoningsrecht kan vallen..$^{2} \mathrm{Zij}$ het dat de Hoge Raad vervolgens oordeelde dat het verschoningsrecht hier mocht worden doorbroken omdat sprake was van 'zeer uitzonderlijke omstandigheden', zodat de gegevens toch moesten worden verstrekt. 53

Vranken I986, p. II8. Vgl. ook Corstens/Borgers 20II, p. I33 die stellen dat het feit dat de hulpzoekende zich tot de hulpverlener heeft gewend onder het verschoningsrecht 'kan vallen'.

50 Zie zijn conclusie onder 5.I4, alsook de conclusie voor HR 3 juli 200I, LJN AB2732, NJ 2002, 8, noot 5 .

5 I F. Vellinga-Schootstra, 'Het medisch verschoningsrecht in strafzaken', DD 20Io, p. 8I5 wijst erop dat ook het gegeven dat iemand is opgenomen geweest in een kliniek voor jeugdpsychiatrie heel precair is.

52 Vgl. de conclusie van Bleichrodt voor HR I6 juni 2009, LJN BH2678, NJ 2009, 603 onder 4.7.

53 Op de rechtspraak over die omstandigheden wordt in het tweede deel van dit stuk ingegaan. 
Ook uit andere uitspraken van de Hoge Raad blijkt dat vrij indirecte informatie als declaraties 'die onderdeel uitmaken van specificaties' van een advocaat, ${ }^{54}$ een agenda van een notaris, ${ }^{55}$ een boekje met ritgegevens en een agenda van een advocaat ${ }^{56}$ onder het verschoningsrecht kunnen vallen. Uit een arrest uit 2009 blijkt voorts dat ook de inhoud van een afgeluisterd telefoongesprek tussen een cliënt en een advocaat, waarin in feite slechts een afspraak voor een bespreking wordt gemaakt, onder het verschoningsrecht kan vallen. De Hoge Raad wees in zijn oordeel echter uitdrukkelijk op de omstandigheden van het geval. Het ging om een (min of meer) voortvluchtige verdachte die een afspraak met de advocaat wilde maken, omdat hij had vernomen dat in zijn woning een huiszoeking was verricht en hij door de politie werd gezocht. ${ }^{57}$

Kennelijk houdt de Hoge Raad ook bij naam- en adresgegevens en het enkele gegeven dat een hulpverleningsrelatie bestaat vast aan het uitgangspunt dat dergelijke gegevens pas onder het verschoningsrecht vallen als door het bekend worden daarvan de vertrouwensrelatie tussen verschoningsgerechtigde en zijn cliënt wordt geschaad.

Dat is jammer. Het laat immers ruimte voor interpretatie. Zulks leidt tot onwenselijke onzekerheid over de reikwijdte van het verschoningsrecht en kan het doel dat het verschoningsrecht wil bereiken - dat eenieder zich vrijelijk tot bepaalde hulpverleners durft te wenden - in gevaar brengen. Bovendien vraag ik mij af of hier geen ruimte wordt gelaten voor een beoordeling die de rechter helemaal niet kan maken. Is het bekend worden van een afspraak bij een therapeut voor seksuele aandoeningen of jeugdpsychiater steeds schadelijk voor de vertrouwensrelatie? En is het bekend worden van het 'enkele feit' dat iemand op een bepaalde dag een afspraak met zijn huisarts heeft - iedereen gaat weleens naar de huisarts, met de meest uiteenlopende klachten - nooit schadelijk voor de vertrouwensrelatie? Zonder verdere informatie over de inhoud van de relatie, is een dergelijke afweging toch niet te maken?

Is het niet helderder voorop te stellen dat naam- en adresgegevens en het enkele gegeven dat een hulpverleningsrelatie bestaat als toevertrouwde wetenschap aan te duiden zijn en deze gegevens dus steeds onder de reikwijdte van het verschoningsrecht te brengen?

Volgens Fernhout bestaan er geen 'neutrale feiten'. Ieder feit krijgt volgens hem een bepaalde lading wanneer daarnaar in een procedure wordt gevraagd. Zoals uit het voorgaande blijkt, wil ik daarin ver met hem meegaan. Ik twijfel echter over de juistheid van de door hem aan dit uitgangspunt verbonden gevolgtrekking dat een arts die een huisbezoek verricht (ook) niet in rechte hoeft te verklaren over de vechtpartij

54 HR 24 mei 20II, LJN BP4663, NJ $2011,262$.

55 HR I5 mei 2007, LJN BA049I, NJ 2007, 300, alsook - maar dat spreekt meer vanzelf - 'aantekeningen, diverse bescheiden en een diskette met daarop een bestand'.

56 HR 30 november I999, LJN ZD7280, NJ 2002, 438, alsook 'aantekeningen'.

57 HR I6 juni 2009, LJN BH2678, NJ 2009, 603. Ik realiseer me dat het hier niet ging om een beroep op het verschoningsrecht maar om de vraag of gegevens die met behulp van een telefoontap waren verkregen mochten worden gebruikt; voor de vraag of sprake is van toevertrouwde wetenschap is dat verschil m.i. niet relevant. 
in de woning van zijn patiënt. ${ }^{8}$ Het enkele feit dat het gaat om toevertrouwde wetenschap is namelijk niet voldoende om een beroep op het verschoningsrecht te laten slagen.

\subsection{Normale beroepsuitoefening}

Blijkens de tekst van artikel $218 \mathrm{~Sv}$ is in de tweede plaats vereist dat de wetenschap aan de beroepsgeheimhouder 'als zodanig' - met andere woorden: in zijn normale beroepsuitoefening - is toevertrouwd. ${ }^{59}$ Zo zal de advocaat die betrokken raakt bij een aanrijding zich niet op het verschoningsrecht kunnen beroepen, wanneer hij nadien in de strafzaak tegen de veroorzaker van het ongeval als getuige wordt gehoord. Het uitgangspunt brengt voorts mee dat het verschoningsrecht niet geldt ten aanzien van wetenschap die de verschoningsgerechtigde reeds bezat voordat hij zijn werkzaamheden begon, ook al wordt die wetenschap hem nadien nogmaals medegedeeld. ${ }^{60}$

Uit de jurisprudentie van de Hoge Raad wordt voorts duidelijk dat een arts, advocaat of notaris geen aanspraak op het verschoningsrecht kan maken wanneer werkzaamheden worden verricht in een geheel andere beroepshoedanigheid. Zoals eerder is opgemerkt, komt aan de mediator geen beroep op het verschoningsrecht toe. Dat verandert niet wanneer de mediator ook advocaat is ${ }^{6 \mathrm{r}}$ De werkzaamheden worden in deze gevallen feitelijk in een andere hoedanigheid verricht. Het beroep van advocaat is dan slechts een toevallige omstandigheid, die niet kan rechtvaardigen dat de mediator in dat geval een verschoningsrecht toekomt. ${ }^{62}$ Aangenomen wordt dat hetzelfde geldt voor de advocaat die als curator in een faillissement optreedt. ${ }^{63}$

Klaassen heeft gewezen op de mogelijkheid dat de mediator, die tevens advocaat is, tijdens een mediation even zijn 'mediatiorspet' afzet en zijn 'advocatenpet' opzet om partijen op de juridische consequenties van bepaalde keuzes te wijzen. Volgens haar rechtvaardigt dat op zichzelf nog niet de gevolgtrekking dat de informatie die rond dat punt vervolgens wordt uitgewisseld de advocaat-mediator kennelijk uitsluitend als advocaat ter kennis wordt gebracht. ${ }^{64}$

Daarmee kiest zij eenzelfde benadering als Vranken. Volgens hem moet in gevallen van 'dubbelfuncties' waarin geen duidelijke scheiding tussen de verschillende hoedanigheden kan worden aangebracht, gekeken worden op welk soort

58 Fernhout 2004, p. 2II. Aan het tweede vereiste (zie de volgende paragraaf) is m.i. niet voldaan. Over de mishandeling zal daarom gewoon moeten worden verklaard; de vraag 'waarom was u in de woning' mag echter onbeantwoord blijven.

59 HR I maart I985, NJ I986, I73, r.o. 3.4: het verschoningsrecht strekt zich alleen uit tot 'datgene waarvan de wetenschap hem als zodanig, dat wil zeggen als notaris, is toevertrouwd'.

6o Verburg I975, p. I03 alsook Melai/Groenhuijsen e.a., aant. II.2 op art. 2 I8 Sv met verwijzing naar Gerecht Eerste Aanleg Curaçao I4 april I975, NJ I975, 453.

6I Vgl. ook HR 29 maart I994, NJ I994, 537 waarin een advocaat als 'directeur/protector' was opgetreden, alsook HR 8 december 1995 , NJ I996, 708 waarin een notaris als procuratiehouder fungeerde.

62 Zie in die zin ten aanzien van de (advocaat-)mediator HR Io april 2009, LJN BG9470, NJ 2010, 47I en de conclusie van advocaat-generaal Wesseling-van Gent daarvoor onder 2.50 en 2.5I.

63 Fernhout 2004, p. I98.

64 Vgl. haar noot onder HR Io april 2009, LJN BG9470, NJ 20I0, 47I. 
werkzaamheden het zwaartepunt ligt. Een mediator komt dan geen verschoningsrecht toe, ook niet ten aanzien van de door Klaassen bedoelde informatie. Voor zover dat tot onwenselijke resultaten leidt, kan de rechter - als een soort hardheidsclausule - de vertrouwelijkheid van dergelijke informatie waarborgen door zijn bevoegdheid te beletten dat aan een aan de getuige gestelde vraag gevolg wordt gegeven. ${ }^{65}$

Of een beroep op het verschoningsrecht kan worden gedaan, moet worden afgemeten aan de werkzaamheden die het ambt of het beroep van de verschoningsgerechtigde kenmerken. ${ }^{66}$ Dat de advocaat die tijdens een bespreking de gekwetste duim van zijn cliënt verbindt niet in de normale uitoefening van zijn beroep handelt, spreekt voor zich. Zulks in tegenstelling tot een arts die dezelfde handeling verricht. ${ }^{67}$ Werkzaamheden die bij de ene beroepsgroep aanleiding geven tot het verschoningsrecht, doen dat niet (vanzelfsprekend) bij de andere. Het oordeel dat een notaris een beroep kan doen op het verschoningsrecht ten aanzien van zijn juridisch advieswerk, heeft dan ook niets te maken met het feit dat hetzelfde juridisch advieswerk (wel) onder het verschoningsrecht valt als het door een advocaat zou zijn verricht, maar dient te berusten op een eigen maatschappelijke rechtvaardiging.

Het is duidelijk dat de artsen, advocaten en notarissen in hun normale beroepsuitoefening handelen, wanneer zij hun patiënten of cliënten bijstand verlenen door het verrichten van de tot hun domeinmonopolie behorende handelingen. De werkzaamheden van deze beroepsgroepen zijn echter niet tot deze voorbehouden handelingen beperkt. Dat kan ook niet. Het voorschrijven van geneesmiddelen of (afzien van) het voeren van een procedure of opmaken van een akte gaat immers noodzakelijkerwijze gepaard met het geven van advies. De effectiviteit van de bijstand zal vaak in belangrijke mate afhangen van de advisering. Dat deze beroepsbeoefenaars hun deskundigheid ook in dat verband aanwenden is dus van wezenlijk belang voor de hulpverleningstaak die zij vervullen ter bescherming van de volksgezondheid, rechtspleging en rechtszekerheid. Dat rechtvaardigt dat ook hetgeen de verschoningsgerechtigde in dat verband wordt toevertrouwd onder het verschoningsrecht valt. Dat dit advieswerk op zichzelf niet aan deze beroepsgroepen is voorbehouden en dus ook door anderen zou kunnen worden verricht, is geen reden om hun het verschoningsrecht ten aanzien van deze werkzaamheden te onthouden. Dat vindt ook erkenning in de rechtspraak van de Hoge Raad. In die rechtspraak staat immers voorop dat het verschoningsrecht beoogt te waarborgen dat mensen zich zonder vrees voor openbaarmaking voor zowel bijstand als advies tot deze hulpverleners kunnen wenden. ${ }^{68}$

Kortom, een beroep op het verschoningsrecht zal niet kunnen slagen in de gevallen waarin in een geheel andere beroepshoedanigheid of als privépersoon

65 Vranken 1986, p. 83.

66 Verburg 1975, p. 62 acht de aard van de gebruikelijke of noodzakelijke werkzaamheden bepalend.

67 Fernhout 2004, p. 199.

68 HR I maart I985, NJ I986, I73, r.o. 3.I. 
werkzaamheden zijn verricht en omgekeerd zal een dergelijk beroep steeds opgaan wanneer door de arts, advocaat of notaris de tot zijn domeinmonopolie behorende werkzaamheden worden verricht of wanneer hij omtrent die werkzaamheden adviseert. Daarmee zijn echter slechts de buitengrenzen van de normale beroepsuitoefening geschetst. Over de vraag of, en zo ja in hoeverre, ook de wetenschap die is toevertrouwd in het kader van andere werkzaamheden onder de reikwijdte van het verschoningsrecht valt, verschillen de juridische schrijvers van mening. Aan de hand van enkele in de literatuur ingenomen standpunten ga ik hierna op deze vragen in.

\section{Advocaat}

De voor de advocaat kenmerkende werkzaamheden zijn het verlenen van (proces)bijstand en het adviseren over zowel het formele als materiële recht. ${ }^{69}$ In het in 2006 verschenen eindrapport van de Commissie Advocatuur werden deze werkzaamheden aangemerkt als de hoofdonderdelen van de daar omschreven kerntaak van de advocaat in de rechtstaat: het waarborgen van de rechtspositie van de cliënt. ${ }^{\circ}$

Van Domburg heeft gesteld dat alleen 'beroepsspecifieke werkzaamheden' onder het verschoningsrecht vallen. Daarmee bedoelt hij dat werkzaamheden die ook door niet-advocaten kunnen worden verricht, zijn uitgezonderd. Advieswerk kan volgens hem dan ook slechts aanleiding tot het verschoningsrecht geven, wanneer het in het verlengde van bijstandsverlening ligt, zoals advisering over de mogelijkheden van hoger beroep of over bepaalde juridische aspecten van een echtscheidingsprocedure. $^{7 \mathrm{~T}}$

Die beperking lijkt evenwel de samenhang tussen adviseren en procederen te miskennen. Een goede kennis van het materiële recht is immers nodig om effectief te kunnen procederen of juist om te kunnen beslissen van het voeren van een procedure af te zien..$^{2}$ Gelijke samenhang kan worden aangenomen ten aanzien van het voeren van onderhandelingen en treffen van schikkingen. Procederen, adviseren, onderhandelen en schikken staan in rechtstreeks verband met de hiervoor beschreven kerntaak van de advocatuur. De wetenschap die in het kader van al die werkzaamheden wordt verkregen, valt naar mijn oordeel steeds onder het verschoningsrecht. ${ }^{73}$ Het verschoningsrecht wil immers die hulpverleningstaak als zodanig

69 Spronken 2009, p. 97.

70 De commissie - beter bekend als de commissie-Van Wijmen - werd in 2005 door o.m. de minister van Justitie ingesteld met als opdracht het analyseren van de rol en positie van de advocatuur in de rechtsstaat en de rechtsorde. In 2006 presenteerde de commissie haar rapport Een maatschappelijke Orde. Momenteel is een wetsvoorstel strekkende tot herziening van de Advocatenwet aanhangig (Kamerstukken II 2009/IO, 32 382, nr. 2; Wet positie en toezicht advocatuur) dat (deels) op de aanbevelingen van de commissie is gebaseerd.

7I Van Domburg i994, p. 8I-82.

72 Vgl. de toelichting op het genoemde wetsvoorstel: Kamerstukken II 20II/I2, 32 382, nr. Io, p. 43, alsook Spronken 2009, p. III en Melai/Groenhuijsen e.a., aant. II.2 op art. 2 I8 Sv.

73 Zie in die zin ook het eindrapport van de Commissie Advocatuur, p. 20. Eerder werd al gewezen op de uitzonderingen die in civielrechtelijke rechtspraak zijn gemaakt ten aanzien van de geschillen tussen onderhandelende partijen onderling of met belanghebbende derden. 
waarborgen. Dat in die hulpverleningstaak ook werkzaamheden worden betrokken die ook door (niet verschoningsgerechtigde) anderen kunnen worden verricht, doet daaraan niet af. Dat een advocaat zijn cliënt procesbijstand verleent in een procedure waarvoor geen verplichte procesvertegenwoordiging geldt, is daarom geen argument om aan te nemen dat deze procesbijstand niet (langer) behoort tot de normale beroepsuitoefening van de advocaat en om de advocaat ten aanzien van deze werkzaamheden het verschoningsrecht te onthouden.74

In de literatuur is voorts het standpunt ingenomen dat louter financiële dienstverlening, zoals het openen van bankrekeningen ten behoeve van een cliënt en het voeren van het beheer daarover, geen werkzaamheid betreft die onder het verschoningsrecht valt. ${ }^{75}$

Dat het echter lastig is grenzen te trekken, blijkt uit de discussie die ontstond toen het College van beroep voor het bedrijfsleven in 1996 oordeelde dat een advocaat die van zijn (buitenlandse) cliënt betalingen ontvangt ter doorgeleiding aan een derde, zijn beroepsgeheimhoudingsplicht niet met vrucht kan tegenwerpen aan een op de Wet financiële betrekkingen buitenland 1994 gegrond verzoek van de Nederlandsche Bank om de persoonsgegevens van de cliënt te verstrekken. Het College betrok in zijn oordeel dat de cliënt de betaling door de advocaat had laten verrichten (slechts) met de intentie om die betaling geheim te houden..$^{6}$

Volgens Mout moet het doorgeleiden van betalingen worden aangemerkt als financiële dienstverlening die door iedereen kan worden verricht. Hij vindt het daarom 'geenszins vanzelfsprekend' dat indien een advocaat de betalingen verricht hem ter zake (wel) een beroep op het verschoningsrecht toekomt. Ook niet als de te verrichten betaling verband houdt met een aangelegenheid waaromtrent hij in zijn hoedanigheid van advocaat is geraadpleegd. Mout vindt het terecht dat in dit soort gevallen van 'opzettelijke omleiding' een beroep op het verschoningsrecht wordt geweigerd. ${ }^{77}$

De benadering van de toenmalige landelijk deken van de Nederlandse Orde van Advocaten Huydecoper was omgekeerd. Hij meent dat betalingen in beginsel wel onder het verschoningsrecht vallen, omdat aan (haast) iedere betaling een voorgeschiedenis is verbonden en cliënten erop moeten kunnen vertrouwen dat die geschiedenis niet door de goede verstaander kan worden afgeleid uit de betalingsgegevens die de advocaat aan een instantie zou moeten verstrekken. Wil iedereen

74 Terecht keert Fernhout zich dan ook tegen de overweging waarmee de Nationale ombudsman de klacht dat een advocaat tijdens een fiscale hoorzitting ten onrechte een beroep op het verschoningsrecht was onthouden ongegrond verklaarde. De ombudsman overwoog dat in fiscale procedures het verschoningsrecht niet aan de orde is en dat, indien dit anders zou zijn, 'dit tot gevolg [zou] hebben dat voor de advocaat-vertegenwoordiger andere rechten en verplichtingen gelden dan voor andere vertegenwoordigers.' Nationale ombudsman 2I december I999, nr. 99/518, AB 2000, I9I. Fernhout 2004, p. 207. Anders: H. Montrée en T. Jongbloed, 'Vertrouwelijkheid en verschoningsrecht bij civiele mediations', in: G. Frerks e.a. (red.), Refelectie op mediation, Apeldoorn-Antwerpen: Maklu 2009, p. I9.

75 D.R. Doorenbos, 'Witwassen en (misbruik van) verschoningsrecht', Advocatenblad I996, p. II3 en Melai/Groenhuijsen e.a., aant. II.2 op art. $218 \mathrm{~Sv}$.

76 CBb 23 april I996, nr. 95/094I/075/200, LJN ZGo440.

77 C.Ch. Mout, 'Advocaat en verschoningsrecht, een reactie', Advocatenblad I996, p. 576. 
zich werkelijk vrijelijk tot een advocaat kunnen wenden, dan kan het verschoningsrecht geen lacunes velen. Geheimhouding van een zaak die men zijn advocaat toevertrouwt, vereist noodzakelijkerwijs geheimhouding ten aanzien van de uitvoering die de advocaat aan de instructies van zijn cliënt geeft..$^{8}$

Dat advocaten er niet zijn voor het verlenen van financiële diensten lijkt me een juist uitgangspunt. Het gaat hier om werkzaamheden die juridisch karakter ontberen en die ook door anderen kunnen worden verricht. Daarin kunnen aanwijzingen worden gevonden dat hier op zichzelf geen taak (meer) is weggelegd voor de advocatuur. ${ }^{79}$ Zoals eerder is opgemerkt, wil ik uit die omstandigheden echter niet afleiden dat deze werkzaamheden in geen enkel geval kunnen behoren tot de normale beroepsuitoefening van de advocaat, in die zin dat het verschoningsrecht zich nooit uitstrekt tot de wetenschap die in verband met die werkzaamheden is toevertrouwd. Daarvoor zal immers moeten worden beoordeeld of de verrichte werkzaamheden in rechtstreeks verband staan met de eerder beschreven kerntaak van de advocatuur. ${ }^{80}$ Kan in redelijkheid nog worden gezegd dat de verrichte werkzaamheden zijn gericht op het waarborgen van de rechtspositie van de cliënt?

In 2006 werd een advocaat in de zaak tegen zijn eigen cliënt als getuige opgeroepen om onder meer vragen te beantwoorden over mededelingen van zijn cliënt. Volgens het Openbaar Ministerie vielen de mededelingen niet onder het verschoningsrecht van de advocaat. De cliënt zou namelijk (ook) een vriend van de advocaat zijn en de mededelingen zouden niet aan de advocaat in de hoedanigheid van advocaat maar in het kader van de vriendschap zijn gedaan. ${ }^{8 \mathrm{I}}$ Voor het antwoord op de vraag of een beroep op het verschoningsrecht kan worden gedaan, is naar mijn oordeel echter niet relevant of ook sprake was van vriendschap. Het gaat erom of de gevoerde gesprekken, althans de mededelingen waarop het Openbaar Ministerie het oog had, in rechtstreekse samenhang staan met de rechtsbijstandsverlening van deze advocaat. $^{82}$

78 J.L.R.A. Huydecoper, 'Openheid en vertrouwen', Advocatenblad I996, p. $40 \mathrm{I}$ en 'Reactie van de deken', p. 577.

79 In het rapport van de Commissie Advocatuur, p. 26 wordt opgemerkt dat de advocaat die in het geheel geen werkzaamheden in 'the shadow of the law' verricht, het beroep van advocaat feitelijk niet meer uitoefent. De maatschappelijk legitimatie van zijn bijzondere positie is dan weggevallen.

8o M.A. Wisselink, Beroepsgeheim, ambtsgeheim en verschoningsrecht, Deventer: Tjeenk Willink 1997, p. 82: 'Alleen als het uitzonderlijke geval zich zou voordoen dat een trusteeschap van een advocaat direct zou samenhangen met rechtsbijstand, zou dit tot zijn eigenlijke taak kunnen behoren en verschoningsrechtelijke bescherming genieten'. Daarbij verwijst hij naar Van Domburg, doch die sluit trustwerkzaamheden geheel uit, als ik het goed zie (p. 82).

8I Ook de verhorende rechter-commissaris oordeelde dat de advocaat ten aanzien van door hem aangeduide vragen geen beroep op het verschoningsrecht toekwam, zij het om andere redenen. Rb. Amsterdam 6 december 2006, NbSr 2008, 96. Op de beslissing kwam veel kritiek. Zie voor een overzicht: Spronken 2009, p. III. De weigering van de advocaat bleef uiteindelijk overigens zonder consequenties. Het Openbaar Ministerie heeft nadien niet meer verzocht de advocaat te horen.

82 Vgl. F.A.W. Bannier, 'Het verschoningsrecht en de affaire Meijering', NJB 2007, p. 99I. 


\section{Notaris}

In de literatuur over het notariaat zijn vergelijkbare standpunten te onderscheiden. Volgens Kraan ziet het verschoningsrecht van de notaris slechts op de werkzaamheden die door de notaris 'plegen te worden verricht'. Daaronder verstaat hij de werkzaamheden die niet (ook) door andere (niet verschoningsgerechtigde) beroepsgroepen kunnen worden gedaan. ${ }^{8}{ }^{3}$ Het verzorgen van een aangifte successierecht ligt volgens Kraan inmiddels in die mate (ook) op het terrein van anderen dat geen specifieke noodzaak meer bestaat daarvoor een notaris in te schakelen. Het verzorgen van een dergelijke aangifte is daarom geen werkzaamheid die een notaris pleegt te verrichten. Dat het gebruikelijk is dat een notaris een dergelijke aangifte verzorgt, doet daaraan volgens Kraan niet af. Het geven van belastingadviezen valt, volgens Kraan, slechts onder het verschoningsrecht, indien het gaat om advies over de gevolgen voor het belastingrecht van een op het gebied van het notariële recht liggende constructie. In andere gevallen handelt de notaris als belastingadviseur en komt hem geen verschoningsrecht toe.

Kraan stelt in feite dezelfde eisen als die door Van Domburg ten aanzien van de advocatuur zijn verdedigd. ${ }^{84} \mathrm{Ik}$ merkte al op dat het stellen van deze eisen naar mijn oordeel te veel nadruk legt op de vraag of bepaalde werkzaamheden ook door andere beroepsgroepen kunnen worden verricht. Uit het oog wordt dan verloren dat het verschoningsrecht de beschikbaarheid van hulpverlening als zodanig wil waarborgen en dus niet vereist dat voor iedere afzonderlijke werkzaamheid geldt dat mensen zich daarvoor slechts tot deze verschoningsgerechtigde beroepsgroep kunnen wenden. Het beoordelingscriterium is dan ook het rechtstreeks verband tussen de werkzaamheden en die hulpverleningstaak. ${ }^{85}$ De notaris is de deskundige bij uitstek op het gebied van de afwikkeling van nalatenschappen. Kan dan werkelijk worden volgehouden dat de notaris die in aansluiting op een dergelijke afwikkeling ook de aangifte successiebelasting verzorgt niet meer in de normale beroepsuitoefening handelt, in die zin dat hem geen beroep op het verschoningsrecht toekomt ten aanzien van de wetenschap die hem (slechts) in dat verband werd toevertrouwd?

Een vraag die schrijvers over het notariaat verdeeld houdt, is of de notaris in zijn rol van partijadviseur nog handelt in zijn normale beroepsuitoefening. Het verlenen van dergelijk advies lijkt zich moeilijk te verhouden met de ordenende taak die de notaris heeft in het civielrechtelijke rechtsverkeer en de onafhankelijke positie die de hij daarbij moet (kunnen) innemen. Sterker nog, zo menen sommigen, indien notarissen veelvuldig als adviseur voor slechts een partij optreden, schaadt dat

83 Kraan 2007, p. 82-87 en 98-100.

84 Ten aanzien van het notariaat zegt hij het minder duidelijk, maar vermoedelijk legt Van Domburg de grens op dezelfde plek. Hij stelt immers als voorwaarde dat het moet gaan om 'noodzakelijke hulpverlening voor de in juridische nood verkerende hulpzoekende'. Van Domburg 1994, p. 90.

85 Vgl. in die zin ook Melis/Waaijer 2012, p. 242. 
de bijzondere positie van de notaris. Het risico bestaat dan dat notarissen geloofwaardigheid verliezen wanneer zij op andere momenten boven de partijen moeten staan. ${ }^{86}$

Lekkerkerker constateert dat het optreden als partijadviseur echter deel is gaan uitmaken van de werkzaamheden van de notaris en dat de notaris aldus in het civielrechtelijke rechtsverkeer als vertrouwensman en rechtshulpverlener fungeert op gelijke voet met de advocaat. Hij behoort (daarom?) op dezelfde wijze als de advocaat het verschoningsrecht te hebben. ${ }^{87}$ Kraan wil slechts dan het bestaan van het verschoningsrecht aannemen, indien voor de partij de noodzaak bestond zich voor de behartiging van zijn belangen op rechtskundig gebied tot een notaris te wenden. Waaijer ziet voor de partijadviseur eigenlijk slechts een rol in de context van juridische bijstand in het kader van transacties tussen grote (beursgenoteerde), veelal internationaal opererende marktpartijen. Het gaat dan om professionele partijen waar het risico op juridische onkunde en feitelijk overwicht niet aan de orde is. In die gevallen is het naar zijn oordeel niet reëel dat één, onpartijdige notaris optreedt - door kennisachterstand zou deze in feite als 'stempelnotaris' fungeren - en acht hij bij de partijadviseurs nog 'voldoende notarieel DNA' aanwezig om het verschoningsrecht te rechtvaardigen. ${ }^{88}$

De redenering van Lekkerkerker is naar mijn oordeel onvoldoende om te rechtvaardigen dat de hier bedoelde werkzaamheden onder het notariële verschoningsrecht worden gebracht. Zoals hiervoor ten aanzien van de advocaat en de gewonde duim is opgemerkt, is daarvoor de vaststelling dat dezelfde werkzaamheden bij andere beroepsgroepen wel aanleiding geven tot het verschoningsrecht onvoldoende. Kraan stelt de grenzen te scherp. Waaijer lijkt de redenering om te draaien en vooral te beargumenteren waarom het door hem bedoelde advieswerk wel aanleiding tot het verschoningsrecht zou moeten geven. Overtuigend vind ik het niet. Waarom zou geen beroep op het verschoningsrecht kunnen worden gedaan door de notaris die een particulier of niet-beursgenoteerd bedrijf heeft geadviseerd over een (concept van een) door een andere notaris te verlijden akte?

Arts

De vraag wat kan worden aangemerkt als de normale beroepsuitoefening, dient bij de arts veeleer te worden opgevat als de vraag naar een behandelrelatie. Alleen aan de behandelend arts komt het verschoningsrecht toe. ${ }^{89}$

Er zijn tal van situaties waarin door artsen (gebruikelijke) handelingen op het gebied van de geneeskunst worden verricht, waarbij geen sprake is van een behandelrelatie. Het gaat daarbij met name om bedrijfsartsen en keuringsartsen die

86 Vgl. paragraaf 3.2.2 van bijlage X bij het eindrapport van de Parlementaire enquêtecommissie opsporingsmethoden (commissie-Van Traa) uit I996.

87 G.J.C. Lekkerkerker, 'De notaris en zijn eigen waarde; een kijk op het beroep, beroepsplichten en realiteiten van het hier en nu', in: G.J.C. Lekkerkerker e.a., De goede notaris, over notariële deontologie, Den Haag: Sdu Uitgevers 20I0, p. 57.

88 Melis/Waaijer 20I2, p. 383 en 387.

89 HR I5 oktober I999, LJN AA3797, NJ 200I, 42, r.o. 3·3.2. 
werkzaam zijn in het kader van arbeidsomstandigheden- en de arbeidsongeschiktheidsregelingen en om artsen die werkzaamheden ten behoeve van justitie verrichten. In die laatste categorie vallen de inrichtingsartsen werkzaam in gevangenissen, tbs-instellingen en justitiële jeugdinrichtingen, artsen die observeren en rapporteren ten behoeve van de oplegging of tenuitvoerlegging van sancties en artsen die bijstand verlenen aan de opsporing.

Van een zuivere tegenstelling is overigens geen sprake. Werknemers kunnen zich ook op eigen initiatief tot de bedrijfsarts wenden voor bijstand en advies en inrichtingsartsen verlenen veelal ook de normale huisartszorg in hun inrichting. In dergelijke gevallen is wel sprake van een behandelrelatie..$^{\circ}$

Dat aan de niet-behandelend arts niet het verschoningsrecht toekomt, kan rechtstreeks op de grondslag daarvan worden gebaseerd. Hier speelt immers niet het algemeen belang dat men zich tot hen voor bijstand en advies moet kunnen wenden. ${ }^{\text {I }}$

Volgens Verburg komt aan de niet-behandelend arts slechts het verschoningsrecht toe voor zover hij wordt gevraagd te getuigen over de wetenschap die hij anders dan in verband met zijn opdracht heeft opgedaan. Volgens hem rechtvaardigt het in het algemeen toch delicate karakter van geneeskundig onderzoek deze beperking..$^{92}$

Die uitkomst en redenering spreken mij niet aan. Het verschoningsrecht ziet immers niet op het delicate karakter van geneeskundig onderzoek of op het beschermen van vertrouwensrelaties als zodanig. Naar mijn oordeel moet hier dan ook aanknoping worden gezocht bij de door Vranken voorgestelde aanpak bij dubbelfuncties. Van het hier aan de orde zijnde verschoningsrecht kan slechts sprake zijn, indien een duidelijke scheiding tussen de werkzaamheden kan worden gemaakt. Vermoedelijk zal dat veelal het geval zijn in de gevallen waarin een bedrijfs- of inrichtingsarts in een behandelrelatie zorg verleent. In andere gevallen komt aan een niet-behandelend arts niet het verschoningsrecht van de arts toe.

Dat wil overigens niet zeggen dat de door Verburg bedoelde wetenschap steeds met de rechter moet worden gedeeld. Zo de niet-behandelend arts niet reeds op een andere grond aanspraak op verschoningsrecht kan maken - verschoningsrecht kan ook worden gebaseerd op een wettelijke geheimhoudingsplicht of zijn verbonden aan het uitoefenen van een beroep waarmee andere zwaarwegende maatschappelijke belangen zijn gemoeid die vertrouwelijkheid vereisen - kan de vertrouwelijkheid van dergelijke wetenschap in ieder geval worden gewaarborgd door de bevoegdheid van de rechter bij een getuigenverhoor om vragen of informatie te beletten. ${ }^{93}$

90 Vgl. de toelichting op het Besluit van I3 maart 2000, houdende aanwijzing van situaties, bedoeld in artikel 464 van Boek 7 van het Burgerlijk Wetboek (Stb. 2000, I2I).

9I Melai/Groenhuijsen e.a., aant. II.2 op art. 2 I8 Sv. Anders ten aanzien van de verzekeringsarts: Bannier e.a. 2008, p. 94.

92 Verburg 1975 , p. 136.

93 Zie bijvoorbeeld Fernhout 2004, p. 269 ten aanzien van art. Io Wet op de medische keuringen, en HR I5 oktober 1999, LJN AA3797, NJ 200I, 42, waarin aan een vertrouwensarts het verschoningsrecht van de arts werd onthouden maar wel een (beperkt) verschoningsrecht wegens andere dan hulpverleningsbelangen werd aangenomen. 
De oplossing van het beletten van (de beantwoording van) vragen moet ook worden gekozen, indien de arts beschikt over patiëntgegevens in het kader van medischwetenschappelijk onderzoek. Toen in de jaren tachtig van de twintigste eeuw een sociologisch-wetenschappelijk onderzoeker als getuige in een strafzaak bij de rechtbank was opgeroepen, weigerde deze de hem gestelde vragen te beantwoorden. Hij onderbouwde dat als volgt: 'Ik ben sociologisch onderzoeker. Ik ben niet bereid achtergrondinformatie te geven omtrent situaties en personen beschreven in mijn rapport: zonder anonimiteit die de onderzoeker moet kunnen garanderen kan geen sociologisch onderzoek plaatsvinden'. De Hoge Raad oordeelde in zijn arrest dat aan een sociologisch onderzoeker niet het in artikel 2 I8 Sv bedoelde verschoningsrecht toekomt, doch dat hetgeen door de getuige is betoogd voor de rechtbank reden had kunnen zijn om het beantwoorden van vragen te beletten. ${ }^{94}$

Advocaat-generaal Remmelink kwam in zijn conclusie voor dit arrest tot dezelfde oplossing. Hij wees echter daarnaast op het geval waarin een arts sociaal-medisch onderzoek doet naar het voorkomen van bepaalde psychische of fysieke afwijkingen en daartoe in een bepaalde stadswijk een aantal mensen interviewt. De arts zou ten aanzien van die werkzaamheden (wel) een beroep op zijn verschoningsrecht kunnen doen. Ik deel die mening niet. Het zou (voor mij) anders zijn, indien de arts wetenschappelijk onderzoek verricht met gegevens die hem eerder reeds in een behandelrelatie waren toevertrouwd. Dat daarna met die gegevens wetenschappelijk onderzoek wordt gedaan, maakt voor het bestaan van het verschoningsrecht dan geen verschil.

\subsection{Het verschoningsrecht als dekmantel?}

Ook werkzaamheden die op zichzelf behoren tot de normale beroepsuitoefening kunnen worden ingezet om strafbare feiten te plegen. Door medewerking te verlenen aan de overdracht van onroerende zaken of de oprichting van vennootschappen, kan de notaris een rol vervullen bij ABC-transacties of fraude. De advocaat kan juridisch advies verlenen bij criminele transacties. Deze deelname aan criminele activiteiten kan bewust zijn. De beroepsbeoefenaar kan echter ook in opdracht van zijn cliënt zijn gebruikelijke werkzaamheden verrichten zonder van de slechte intenties van zijn cliënt op de hoogte te zijn.

In de literatuur wordt veelal tot uitgangspunt genomen dat de wetenschap die wordt verkregen als de beroepsbeoefenaar zijn cliënten, bewust of onbewust, behulpzaam is bij het plegen van strafbare feiten niet onder de reikwijdte van het verschoningsrecht valt. 95

Volgens Verburg betekent het aanvaarden van een beroep op het verschoningsrecht in dergelijke gevallen dat de grondslagen van het verschoningsrecht worden verlaten. Daarbij stelt hij voorop dat het verschoningsrecht slechts de vertrouwensrelatie beoogt te beschermen tussen een beroepsuitoefenaar en degenen die werkelijk in nood verkeren, opdat de laatsten niet worden weerhouden van het inschakelen 
van hulp. In de hier bedoelde gevallen schaadt de verplichting tot spreken van de beroepsbeoefenaar deze vertrouwensrelatie die het verschoningsrecht beoogt te waarborgen niet. In het concrete geval bestaat zij immers niet. Maar ook in het algemeen wordt deze relatie niet geschaad: bij bona fide hulpzoekers behoeft immers geen twijfel omtrent de onaantastbaarheid van de vertrouwensrelatie te ontstaan. ${ }^{96}$

Met de uitkomst van de redenering ben ik het eens: gevallen waarin het verschoningsrecht wordt ingezet om strafbare feiten te verhullen, vallen niet onder de reikwijdte van dat recht. Hier is geen sprake van de in het algemeen belang noodzakelijk geachte hulpverlening die het verschoningsrecht beoogt te beschermen. Of, als ik het probeer in te passen in de bewoording van het hiervoor al aangehaalde arrest uit I99I: openbaarmaking beschaamt dan niet het vertrouwen dat patiënten of cliënten 'met het oog op zijn hulpverlenende taak' in de beroepsuitoefenaar moeten kunnen stellen.

Met andere woorden, het mag zo zijn dat sprake is van wetenschap die in het kader van gebruikelijke werkzaamheden is toevertrouwd en dat door het niet respecteren van de vertrouwelijkheid daarvan de vertrouwensrelatie tussen beroepsbeoefenaar en cliënt wordt geschaad, desalniettemin bestaat hier geen verschoningsrecht. Het gaat hier namelijk niet om een rechtens te respecteren vertrouwensrelatie. Dat volgt reeds uit het feit dat deze relatie is gericht op of - in geval de verschoningsgerechtigde zich van zijn aandeel niet bewust is - wordt misbruikt voor het plegen van criminele feiten. Toch is dat hier niet de kern. De grenzen kunnen nog scherper worden gesteld. De relatie is niet rechtens te respecteren, omdat zij niet is gericht op de hulpverlening die het verschoningsrecht beoogt te beschermen.

Overigens moet wel het verschil voor ogen worden gehouden met de situatie waarin iemand probeert een verschoningsgerechtigde tot deelname aan criminele activiteiten te verleiden, doch deze laatste zijn rug recht houdt. Van misbruik van het verschoningsrecht is dan immers geen sprake. Ook de enkele wetenschap dat een cliënt een strafbaar feit zal (of: wilde) gaan plegen, valt evenmin onder de ook door mij voorgestane uitzondering. ${ }^{97}$

Fernhout vindt dat een vertrouwenspersoon verschoningsrecht heeft, ook als deze zich (on)bewust laat betrekken in dubieuze praktijken. Dergelijk handelen kan aanleiding geven tot straf- en tuchtrechtelijk ingrijpen, maar is volgens hem geen aanleiding om de reikwijdte van het verschoningsrecht te beperken..$^{8}$ Ook Doorenbos lijkt zich op het standpunt te stellen dat voor de beoordeling van de vraag of

96 Verburg i975, p. 58-59.

97 Ook van aangifteplichten is de verschoningsgerechtigde immers vrijgesteld. Dat de verhouding tussen beroepsgeheimhoudingsplicht en de wetenschap dat een cliënt of patiënt een ernstig misdrijf wil plegen tot dilemma's kan leiden, spreekt voor zich. Dat is echter geen reden dergelijke situaties van het verschoningsrecht uit te zonderen. Wel kan de ernst van het feit worden betrokken in de afweging of sprake is van zeer uitzonderlijke omstandigheden op grond waarvan het verschoningsrecht (in dat geval) moet worden doorbroken. Op die doorbreking wordt in het tweede deel van dit stuk teruggekomen.

Fernhout 2004, p. 201. 
werkzaamheden onder het verschoningsrecht vallen de kwade trouw van de cliënt niet relevant is. Later merkt hij evenwel op dat hij het standpunt dat het misplaatst is om een beroep op het verschoningsrecht te doen om criminelen en criminele handelingen af te schermen theoretisch gezien juist vindt. Hij getuigt volgens hem echter van studeerkamergeleerdheid om te stellen dat ten aanzien van de wetenschap die is verkregen in de gevallen waarin het verschoningsrecht wordt gebruikt om strafbare feiten te verhullen geen beroep op het verschoningsrecht kan worden gedaan. De rechter(-commissaris) zou dat standpunt tijdens een doorzoeking ter inbeslagneming namelijk nooit kunnen innemen, omdat de vraag of sprake is van criminele handelingen op dat moment juist nog in onderzoek is. ${ }^{99}$

Die redenering vind ik niet overtuigend. Dat op de naleving van een regel niet (steeds) kan worden toegezien, is toch geen reden de regel dan maar niet te stellen? Voor het maatschappelijk draagvlak van het verschoningsrecht lijkt het mij van groot belang dat ferm wordt vooropgesteld dat het verschoningsrecht geen dekmantel is voor criminele handelingen. ${ }^{100}$ De vraag waar de grenzen liggen, is bovendien niet alleen relevant voor de rechter(-commissaris) maar ook voor de verschoningsgerechtigde beroepsgroepen. Zeker in die gevallen, waarin de verschoningsgerechtigde ontdekt dat hij onbewust heeft bijgedragen aan strafbare feiten.

In 2010 moest de Hoge Raad oordelen over een geval waarin een advocaat zijn kantoor ter beschikking had gesteld aan een cliënt. Op het kantoor had een bijeenkomst tussen de cliënt en derden (de advocaat was zelf niet aanwezig) plaatsgevonden, waarbij een van die derden is afgeperst. ${ }^{\text {Ior }}$ De secretaresse van de advocaat was als getuige gehoord en had verklaard over het plaatshebben van de bijeenkomst. In cassatie spitste de zaak zich toe op de vraag of het hier ging om wetenschap ten aanzien waarvan de (secretaresse van de) advocaat een beroep op het (afgeleid) verschoningsrecht kon doen.

Advocaat-generaal Jörg stelt in zijn conclusie ten behoeve van het arrest van de Hoge Raad voorop dat het verschoningsrecht slechts ziet op de informatie die de beroepsbeoefenaar ontvangt in de normale beroepsuitoefening en zich dus niet uitstrekt tot het door advocaten faciliteren van strafbare feiten van hun cliënten. Volgens Jörg is hier geen sprake van wetenschap die onder het verschoningsrecht valt, maar van een waarneming van een door verzoeker en anderen op het kantoor van zijn advocaat jegens een derde gepleegd strafbaar feit.

In zijn arrest legt de Hoge Raad het gerechtshof dat de zaak in feitelijke aanleg berechtte het oordeel in de mond - in de overwegingen van het hof is geen passage te vinden over de reikwijdte van het verschoningsrecht - dat hier geen sprake is van wetenschap die onder het verschoningsrecht valt. Dat oordeel getuigt volgens de Hoge Raad niet van een onjuiste rechtsopvatting en is niet onbegrijpelijk. Daarbij stelt hij voorop dat het verschoningsrecht slechts betrekking heeft op in het kader

99 Doorenbos I996, p. II3 (noot I7) en II4.

IOo Vgl. in die zin de conclusie van advocaat-generaal Vellinga voor HR 30 oktober 2007, LJN BA56II, NJ 2008, II5 onder 20.

IOI HR I2 oktober 20I0, LJN BNo526, NJ 20II, 537, r.o. 5.3 en de conclusie onder 83 e.v. 
van normale beroepsuitoefening toevertrouwde wetenschap. ${ }^{\text {I02 }}$ Het overnemen van die formulering uit de conclusie - van 'normale beroepsuitoefening' sprak de Hoge Raad in dit verband niet eerder - suggereert dat de Hoge Raad met de advocaat-generaal voor het in dit geval niet bestaan van het verschoningsrecht doorslaggevend heeft geacht dat het kantoor als dekmantel voor een strafbaar feit is gebruikt. Ik houd evenwel een slag om de arm. De uitspraak kan ook zo worden gelezen dat het ter beschikking stellen van kamers niet als normale beroepsuitoefening is gezien en de in dat verband verkregen wetenschap om die reden van het verschoningsrecht werd uitgezonderd.

\section{$7 \quad$ Standpunt verschoningsgerechtigde doorslaggevend?}

Volgens vaste rechtspraak wordt het aan de verschoningsgerechtigde gelaten om te beoordelen of de wetenschap waarnaar in een getuigenverhoor wordt gevraagd onder het verschoningsrecht valt. Diens standpunt daaromtrent wordt door de rechter slechts marginaal getoetst. Vragen behoeven niet te worden beantwoord, zolang de rechter 'aan redelijke twijfel onderhevig acht of die beantwoording naar waarheid zou kunnen geschieden zonder dat geopenbaard wordt wat verborgen dient te blijven'. ${ }^{\text {103 }}$ De afweging of het verschoningsrecht bestaat, wordt in abstracto ten aanzien van de beroepsgroep als geheel gemaakt en er is volgens die rechtspraak - behoudens in de hierna te bespreken zeer uitzonderlijke omstandigheden - geen ruimte om aan de hand van de in het concrete geval spelende belangen af te wegen of het verschoningsrecht ook in dat geval geldt. Met die benadering heeft de Hoge Raad (rechts)zekerheid over de reikwijdte van het verschoningsrecht willen creëren. ${ }^{104}$

In geval van inbeslagneming onder een verschoningsgerechtigde wordt de beoordeling of stukken van het beslag moeten worden uitgezonderd omdat zij onder het verschoningsrecht vallen op vergelijkbare wijze - met ook hier de mogelijkheid tot doorbreking van het verschoningsrecht in zeer uitzonderlijke omstandigheden aan de verschoningsgerechtigde gelaten.

'Wanneer deze zich op het standpunt stelt dat het gaat om brieven of geschriften die noch voorwerp van het strafbare feit uitmaken noch tot het begaan daarvan hebben gediend en waarvan kennisneming zou leiden tot schending van het beroepsgeheim, dient dit standpunt door de organen van politie en justitie te worden geëerbiedigd, tenzij redelijkerwijze geen twijfel erover kan bestaan dat dit standpunt onjuist is. ${ }^{105}$

Met de terughoudende opstelling van de rechter wordt voorkomen dat bij de beoordeling van de vraag of bepaalde informatie onder het verschoningsrecht valt, die

I02 De vooropstelling is hiervoor in haar geheel aangehaald.

I03 HR I maart I985, NJ I986, I73, r.o. 3.5.

IO4 HR 7 juni $\mathrm{I}_{985}$, NJ I986, I74, r.o. 3.

IO5 HR 22 november I99I, NJ I992, 3I5, r.o. 3.3. 
informatie reeds (deels) aan de rechter moet worden prijsgegeven. Het verschoningsrecht beoogt nu juist te bewerkstelligen dat de vertrouwelijkheid ook ten overstaan van de rechter kan worden gegarandeerd. ${ }^{\text {106 }}$

In de literatuur wordt met enige regelmaat de vraag opgeworpen of het (nog) wel gerechtvaardigd is de beoordeling in zo sterke mate aan de verschoningsgerechtigde te laten. De constructie is immers kwetsbaar en misbruikgevoelig. Ook de verschoningsgerechtigde die zijn verschoningsrecht voor zichzelf, al dan niet in samenwerking met zijn cliënt, als dekmantel gebruikt voor gemaakte fouten of criminele activiteiten of de verschoningsgerechtigde die uit onwetendheid een te ruime opvatting over de reikwijdte van het verschoningsrecht hanteert, kan zich op het standpunt stellen dat sprake is van wetenschap die aanleiding geeft tot het verschoningsrecht.

Soms wordt voorgesteld de rechter inzage in de vertrouwelijke informatie te geven en afwegingen aan hem te laten. ${ }^{107}$ Anderen proberen aan de bezwaren tegen (te ruime) inbreuken op de vertrouwelijkheid tegemoet te komen en stellen systemen voor waarin een onafhankelijke commissie of een rechter die niet over de zaak oordeelt na inzage in de informatie beslist of een beroep op het verschoningsrecht kan worden gedaan. ${ }^{\text {108 }}$

Er zijn ook auteurs die het belang van onschendbare vertrouwelijkheid benadrukken. Zij zien in het misbruik de prijs die een rechtsstaat moet betalen om degenen die wel zorgvuldig met hun verschoningsrecht omgaan adequate rechtswaarborgen te bieden. ${ }^{109}$

In een recent arrest lijkt de Hoge Raad zijn uitgangspunt te nuanceren en wordt enige ruimte geboden om het standpunt van de verschoningsgerechtigde te toetsen. ${ }^{\text {IIO }}$ Uit het arrest kan worden afgeleid dat de rechter-commissaris die een doorzoeking ter inbeslagneming verricht in het kader van de marginale toetsing 'voor zover dat noodzakelijk is' mag kennisnemen van de stukken. Ook in gevallen waarin doorzoeking bij de cliënt of patiënt plaatsvindt en deze ten aanzien van bepaalde in beslag te nemen stukken beweert dat het gaat om (afschriften van) vertrouwelijke correspondentie met een verschoningsgerechtigde, is in de rechtspraak aanvaard dat van die stukken mag worden kennisgenomen. Dat kennisnemen is echter slechts toegestaan voor zover dat noodzakelijk is om de bewering op haar aannemelijkheid

Io6 Volgens advocaat-generaal Machielse is dit zelfs de ratio achter de terughoudende opstelling van de rechter. Zie de conclusie voor HR 29 juni 2004, LJN AO5070, NJ 2005, 273 onder 5.I2.

I07 De Bock 20II, p. I75. Zij bespreekt het verschoningsrecht (slechts) vanuit civielrechtelijk perspectief en komt tot de conclusie dat het verschoningsrecht ook vanuit het belang van de betrokken partijen in de procedure beoordeeld moet kunnen worden. De rechter zou per geval moeten kunnen beoordelen of het belang bij de waarheid zwaarder weegt dan instandhouding van de vertrouwelijkheid.

Io8 Zie de noot van Rutgers onder HR I3 januari 2006, LJN AU4533, NJ 2006, 480 en Vranken I986, p. 124 .

Iog Doorenbos I996, p. II3 en Fernhout, p. 201.

IIO HR 2 juli 20I3, LJN CAO434, r.o. 3.4. 
te toetsen. ${ }^{\text {III }}$ Daaraan werden strikte eisen gesteld. Van aannemelijkheid is al sprake indien uit de adressering of het briefhoofd blijkt dat het gaat om correspondentie met een advocatenkantoor. ${ }^{\text {II2 }}$

Hoe verstrekkend de thans aangenomen nuancering bedoeld is, is mij niet duidelijk. Zij lijkt te zien op een inhoudelijke beoordeling van de stukken en daarmee - anders dan de toetsingsmaatstaf suggereert - ruimer te zijn dan de aannemelijkheidstoets in geval van inbeslagneming onder de cliënt. Bovendien gaat het hier om een beroep op het verschoningsrecht in het kader van inbeslagneming. Zou ook in gevallen van getuigenverhoor kunnen worden aangenomen dat verwijzing naar de rechter-commissaris in de rede ligt wanneer de als getuige te horen verschoningsgerechtigde zich op het verschoningsrecht beroept en over zijn standpunt twijfel bestaat?

Duidelijk is wel dat de rechter meer toetsingsruimte heeft en zich minder lijdelijk hoeft op te stellen dan veelal wordt aangenomen.

\section{Beschouwing}

Het waarborgen van vertrouwelijkheid is een essentiële voorwaarde voor de beroepsuitoefening van de arts, advocaat en notaris. Aan deze beroepen is dan ook inherent een beroepsgeheimhoudingsplicht verbonden. Aangezien door deze beroepsgroepen een vorm van hulpverlening wordt geboden die in het algemeen belang noodzakelijk is, is het gerechtvaardigd dat deze beroepsgeheimhoudingsplicht ook ten overstaan van de rechter(-commissaris) in strafzaken in acht kan worden genomen. De vrees dat de vertrouwelijkheid wordt geschonden, moet mensen niet ervan weerhouden deze hulpverleners in te schakelen. Aangezien aldus een groot maatschappelijk belang - de waarheidsvinding in strafzaken - wordt opgeofferd, kan deze mogelijkheid niet onbegrensd zijn. De wetgever heeft het professionele verschoningsrecht dan ook beperkt tot wetenschap die aan de beroepsgeheimhouder 'als zodanig' is 'toevertrouwd'.

Aan de term toevertrouwd wordt een ruime uitleg gegeven. Bezien vanuit het doel dat het verschoningsrecht wil bereiken, is dat terecht. Patiënten en cliënten weten immers niet altijd welke informatie voor de beroepsbeoefenaar van belang is. Zij zouden niet openlijk durven spreken en daardoor voor de hulpverlening relevante informatie kunnen achterhouden, indien zij niet erop kunnen rekenen dat vertrouwelijkheid steeds is gegarandeerd. Bovendien is het min of meer onvermijdelijk dat de beroepsbeoefenaar meer informatie verkrijgt dan de patiënt of cliënt heeft willen delen, zoals bijvoorbeeld de indrukken die de beroepsbeoefenaar tijdens een bespreking opdoet, de informatie die derden verstrekken en het enkele feit dat een hulpverleningsrelatie bestaat. Het zou goed zijn als die onvermijdelijkheid ook ten aanzien van dat laatste punt erkenning vindt in de rechtspraak.

III HR ig november I985, NJ I986, 533, r.o. 5.4.

II2 HR I november I988, NJ I989, 349, r.o. 3.3. 
Die onvermijdelijkheid lijkt een minder grote rol te spelen bij de begrenzing die voortvloeit uit de woorden 'als zodanig'. Of informatie wordt verkregen in de normale beroepsuitoefening heeft de beroepsbeoefenaar immers in grote mate zelf in de hand. Het probleem is echter dat de vraag naar de normale beroepsuitoefening niet steeds helder kan worden beantwoord. Duidelijk is dat aan een persoon die handelt in privéhoedanigheid of in een geheel andere beroepshoedanigheid dan die van arts, advocaat of notaris - bijvoorbeeld in die van faillissementscurator of mediator - geen verschoningsrecht toekomt. Dat die persoon (ook) is ingeschreven als arts, advocaat of notaris doet daaraan niet af. Omgekeerd staat vast dat wanneer een arts, advocaat of notaris ten behoeve van zijn patiënt of cliënt de tot zijn domeinmonopolie behorende handelingen verricht hij zich ten aanzien van de in dat verband toevertrouwde wetenschap steeds op zijn verschoningsrecht kan beroepen. Deze beroepsgroepen zetten - en dat mag van hen worden verwacht - hun deskundigheid ruimer in en leveren ook met verdere werkzaamheden een belangrijke bijdrage aan de bevordering van de volksgezondheid, rechtspleging en rechtszekerheid. Hoewel zij door het verrichten van dergelijke werkzaamheden buiten hun domeinmonopolie treden, en dus werkzaamheden verrichten die ook door andere beroepsgroepen kunnen worden verricht, handelen zij ook in die gevallen in hun normale beroepsuitoefening. Wetenschap die hun in verband met die werkzaamheden wordt toevertrouwd, valt ook onder het verschoningsrecht.

Van normale beroepsuitoefening zal gesproken kunnen worden wanneer de in het algemeen belang aan deze beroepsgroepen opgedragen hulpverlening wordt geboden en de daaruit afgeleide kerntaken alsook de daarmee in direct verband staande werkzaamheden worden verricht. De vraag welke werkzaamheden precies behoren tot de normale beroepsuitoefening laat zich niet in een algemene definitie vatten. De invulling daarvan zal ook in tijd verschillen. De omstandigheid dat andere (niet verschoningsgerechtigde) beroepsgroepen bepaalde werkzaamheden met meer expertise verrichten of de omstandigheid dat bepaalde werkzaamheden medisch respectievelijk juridisch karakter ontberen, kan een aanduiding zijn dat dergelijke werkzaamheden niet (langer) behoren tot de normale beroepsuitoefening van arts, advocaat of notaris en ten aanzien van die werkzaamheden dus geen verschoningsrecht meer bestaat. Doorslaggevend is het echter niet. De in de literatuur ingenomen standpunten dat financiële dienstverlening niet tot de normale beroepsuitoefening van de advocaat behoort en het doen van een aangifte successiebelasting niet tot de normale beroepsuitoefening van de notaris, wil ik niet zonder meer overnemen.

De vraag naar de grenzen van de normale beroepsuitoefening behoort in de eerste plaats door de beroepsgroepen zelf te worden onderzocht. Terecht voorziet het thans aanhangige voorstel tot wijziging van de Advocatenwet niet in een opsomming van werkzaamheden die wel en werkzaamheden die geen aanleiding geven tot het verschoningsrecht, en wordt in de toelichting op het voorstel de advocatuur (wel) opgeroepen tot herbezinning op dit punt. ${ }^{\mathrm{II}}$ 
Van normale beroepsuitoefening is voorts geen sprake indien het verschoningsrecht als dekmantel wordt gebruikt en de arts, advocaat of notaris door een cliënt wordt ingeschakeld om criminele activiteiten te verhullen. De relatie tussen beroepsbeoefenaar en cliënt is dan niet gericht op de door het algemeen belang gevergde hulpverlening door de arts, advocaat of notaris.

Wanneer niet langer sprake is van normale beroepsuitoefening geldt dat geen beroep op het verschoningsrecht kan worden gedaan ten aanzien van de wetenschap die in dat verband aan de verschoningsgerechtigde is toevertrouwd. Dat wordt niet anders, indien uit die informatie wetenschap kan worden afgeleid die wel onder het verschoningsrecht valt. Dat is het risico dat de beroepsbeoefenaar heeft genomen door de grenzen van zijn normale beroepsuitoefening te overschrijden. Terecht hebben de oud-deken van de orde van advocaten en Lekkerkerker in hun hiervoor aangehaalde publicaties erop gewezen dat de verplichte openbaring van dergelijke indirecte informatie schadelijk is voor de vertrouwensrelatie tussen verschoningsgerechtigde beroepsgeheimhouders en hun cliënten. Ik zie daarin evenwel geen argument om dergelijke informatie ook onder het verschoningsrecht te laten vallen. Het verschoningsrecht wil weliswaar de vertrouwensrelatie beschermen, doch die bescherming is geen doel op zichzelf. Het verschoningsrecht beoogt geen oeverloze uitbreiding van die vertrouwensrelatie en de werkzaamheden die kunnen worden verricht door personen die als arts, advocaat en notaris zijn ingeschreven. Slechts hetgeen wordt toevertrouwd in de normale beroepsuitoefening verdient bescherming.

Het omgekeerde geldt evenwel niet. Onjuist is dan ook de opvatting dat wanneer de verschoningsgerechtigde bij het uitvoeren van zijn normale beroepsuitoefening meer gegevens verkrijgt dan hij nodig heeft - bijvoorbeeld indien een notaris met zijn cliënt een bespreking bij een belastingadviseur bijwoont, omdat hij is ingeroepen ter uitvoering van een door een belastingadviseur bedachte constructie - het verschoningsrecht slechts is beperkt tot de informatie die nodig is voor de werkzaamheden die vallen onder de normale beroepsuitoefening. Die opvatting is strijdig met het uitgangspunt dat aan de term 'toevertrouwd' een ruime uitleg moet worden gegeven. ${ }^{\mathrm{II} 4}$

Het standpunt van de arts, advocaat of notaris tijdens een getuigenverhoor of in het kader van een inbeslagneming dat wordt gevraagd naar wetenschap die onder het verschoningsrecht valt, wordt door de rechter slechts marginaal getoetst. Dat past bij het uitgangspunt dat de vertrouwelijkheid tussen verschoningsgerechtigde en zijn cliënt ook door de rechter moet worden gerespecteerd. Om een ruimere beoordeling te kunnen aanleggen, zal de rechter immers (deels) van de aan de verschoningsgerechtigde toevertrouwde wetenschap op de hoogte moeten worden gebracht. Vanwege de marginale toets zal de rechter in veel gevallen niet weten welke werkzaamheden de verschoningsgerechtigde precies voor zijn cliënt heeft

II4 De opvatting lijkt mij voorts in strijd met HR II maart I994, NJ I995, 3, r.o. 3.2. Het voorbeeld is van Kraan (p. 86). 
verricht en ten behoeve van welke van die werkzaamheden bepaalde wetenschap is verkregen.

Ik zie daarin echter geen argument om de vraag naar de grenzen van het verschoningsrecht als 'van academische aard' terzijde te schuiven. De vraag is niet alleen van belang voor de rechter. De maatschappelijke positie van arts, advocaat of notaris vergt van de beoefenaars van deze beroepen dat zij zichzelf grenzen stellen. Dat betekent dat het verrichten van bepaalde werkzaamheden soms moet worden geweigerd en cliënten naar andere hulpverleners moeten worden doorgestuurd of - wanneer in overleg met de cliënt grenzen worden opgezocht - de cliënt goed moet worden voorgelicht over de mogelijke gevolgen voor de geheimhoudingsplicht en het verschoningsrecht.

Dat de rechter slechts een marginale toets kan aanleggen, betekent evenwel niet dat de rechter zich lijdelijk moet opstellen. Indien hij vermoedt dat strafbare feiten worden verhuld of een wel erg exotische werkzaamheid is verricht, zal hij onderzoekend dienen op te treden. Hij kan proberen helder te krijgen of de bijstand tot die ene werkzaamheid beperkt is gebleven of dat ten behoeve van de patiënt of cliënt meer werkzaamheden zijn verricht. De strafrechtadvocaat die in de avonduren aangiften inkomstenbelasting voor buurtgenoten verzorgt, zal zich ten aanzien van de hem in het kader van die werkzaamheden bekend geworden informatie niet met vrucht op het verschoningsrecht kunnen beroepen. De notaris die mediationtechnieken toepast bij de afwikkeling van een nalatenschap tussen ruziënde erfgenamen wel. ${ }^{115}$ Daarbij kan het helpen voor ogen te houden dat de vraag of het verschoningsrecht bestaat niet ten aanzien van het gehele verhoor ineens behoeft te worden beslist, maar per vraag kan worden bekeken. ${ }^{\mathrm{II}}$ In het kader van inbeslagneming is er eveneens ruimte de beslissing per bescheid of bestand te nemen.

\section{Deel II}

\section{Dwangmiddelen en verschoningsrecht: beslag en doorzoeking ${ }^{117}$}

Artikel 2 I8 Sv, dat de professionele verschoningsgerechtigde de mogelijkheid biedt om zich te verschonen van het geven van een getuigenis of van het beantwoorden van bepaalde vragen voor zover het gaat om 'hetgeen waarvan de wetenschap hen als zodanig is toevertrouwd', zou weinig om het lijf hebben wanneer wel beslag zou kunnen worden gelegd op stukken die onder de reikwijdte van het verschoningsrecht vallen of wanneer via de telefoontap vertrouwelijke communicatie in handen van justitie zou kunnen vallen. ${ }^{\text {II8 }}$ Vandaar dat het Wetboek van Strafvordering de

II5 Melis/Waaijer, p. 24I, is vanuit het perspectief van de notaris kritisch over de uitspraak van de Hoge Raad over de advocaat-mediator.

II6 HR 25 mei I999, NJ I999, 580, r.o. 3.6.

II7 De onderdelen 9 tot en met I2 zijn van de hand van Feikje Vellinga-Schootstra. De tekst is afgesloten op 24 juli 2013.

II8 Zie over deze materie in rechtsvergelijkend perspectief C. Brants, T. Spronken, P. Traest en J. Meese, Het verschoningsrecht naar Belgisch recht (Preadviezen voor de Nederlands-Vlaamse Vereniging voor strafrecht), Nijmegen: Wolf Legal Publishers 2006. 
verschoningsgerechtigde bij het toepassen van dwangmiddelen een bevoorrechte positie toekent. Aan deze positionering van de verschoningsgerechtigde bij met name beslag en doorzoeking en - in mindere mate - telecommunicatietap is de laatste 25 jaar veel rechtspraak gewijd, meer dan aan de toepassing van artikel 2I $8 \mathrm{~Sv}$ als zodanig. Daarom, en omdat de omvang van dit preadvies aan grenzen is gebonden, staan het beslag en de doorzoeking bij professionele verschoningsgerechtigden in deze paragraaf centraal.

\section{I De wettelijke regeling}

Artikel 98 lid I Sv bepaalt dat bij de verschoningsgerechtigde geen brieven of andere geschriften in beslag worden genomen waarvan de inhoud valt onder de geheimhoudingsplicht, behoudens toestemming van de verschoningsgerechtigde. ${ }^{\text {I9 }}$ Dit verbod is algemeen, dat wil zeggen niet gekoppeld aan een bepaalde bevoegdheid tot het verrichten van handelingen die inbeslagneming mogelijk maken, zoals de doorzoeking. Het geldt bijvoorbeeld ook wanneer de verschoningsgerechtigde op straat wordt staande gehouden en de opsporingsambtenaar de attachékoffer als 'meegevoerd voorwerp' (artikel $95 \mathrm{~Sv}$ ) in beslag wil nemen. De inbeslagneming waarover artikel $98 \mathrm{~Sv}$ spreekt, is de inbeslagneming in het belang der strafvordering (artikel I34 Sv). Daarmee wordt gedoeld op het beslag ten behoeve van de waarheidsvinding, van het aantonen van wederrechtelijk verkregen voordeel alsmede het - in wezen conservatoire - beslag vooruitlopend op een verbeurdverklaring of onttrekking aan het verkeer van het beslagene door de rechter (artikel 94 lid I en 2 Sv).

Het tweede lid van artikel $98 \mathrm{~Sv}$ legt specifiek de doorzoeking ${ }^{120}$ bij de verschoningsgerechtigde ${ }^{121}$ aan banden. De doorzoeking mag zich niet uitstrekken tot andere brieven of geschriften dan die het voorwerp van het strafbare feit uitmaken of tot het begaan daarvan hebben gediend, ${ }^{\mathrm{I} 22}$ en bovendien mag de doorzoeking - behoudens de toestemming van de verschoningsgerechtigde ${ }^{\mathrm{I} 23}$ - alleen plaatsvinden 'voor zover deze zonder schending van het stands-, beroeps- of ambtsgeheim kan geschieden'.

II Hoewel de bewoordingen anders doen vermoeden is art. $98 \mathrm{~Sv}$ ook van toepassing op o.m. de doorzoeking ter vastlegging van gegevens (art. I25i Sv, zie ook art. I25l Sv).

I20 De Nederlandse wet sprak tot I februari 2000 van 'huiszoeking', waarbij het accent lag op de plaats van onderzoek. Bij de 'doorzoeking' daarentegen staat de wijze van onderzoek centraal. De doorzoeking - het stelselmatig en gericht onderzoek van ieder denkbare plaats - moet worden onderscheiden van de bevoegdheid tot het zoekend rondkijken ter inbeslagneming, waartoe de bevoegdheid tot het betreden van plaatsen, in combinatie met de bevoegdheid tot inbeslagneming, legitimeert; zie hierover Handboek Strafzaken, hfdst. I4 'Doorzoeking' en M.J. Borgers, 'Binnentreden, zoekend rondkijken en doorzoeken. Waar liggen de grenzen onder het nieuwe recht?', DD 2004, 40.

I2I De regeling geldt voor zowel het kantoor als het woonhuis van de verschoningsgerechtigde: HR 30 november 1999, NJ 2002, 438, m.nt. YB. Volgens vaste rechtspraak van het EHRM kan 'home' in art. 8 EVRM ook een kantoor omvatten (recent EHRM I8 april 2013, nr. 264I9 (SaintPaul Luxembourg S.A. t. Luxembourg).

I22 De Hoge Raad heeft geoordeeld dat het verschoningsrecht zich niet uitstrekt tot deze categorie geschriften (HR 20 juni I988, NJ I989, 213).

I23 Onproblematisch is het geven van toestemming vanuit het perspectief van de geheimhoudingsplicht niet. 
Het valt op dat voorwerpen-niet geschriften - te denken is aan bloed- en urinemonsters - geen bijzondere bescherming genieten. Deze kunnen naar de letter van artikel $98 \mathrm{~Sv}$ wel in beslag worden genomen, en naar deze kan ook worden gezocht, voor zover door de zoeking het stands-, beroeps- of ambtsgeheim niet wordt geschonden. De bewoordingen van artikel $98 \mathrm{~Sv}$ zijn gedateerd. Papieren dossiers zijn uiteraard anno 2013 een zeldzaamheid geworden; digitale gegevens die het verschoningsrecht raken, kennen (in artikel I25i e.v. Sv) een soortgelijke bescherming als 'analoge' bescheiden. Het wachten is op één regeling voor beslag op gegevens, ongeacht of deze op papier zijn vastgelegd dan wel in bits en bytes. Zolang deze er nog niet is, lijkt de wetgever ervan uit te gaan dat het bij beslag op papieren stukken gaat om de drager van de gegevens en niet om de gegevens zelf. Dat is een merkwaardig misverstand, dat helaas ook doorklinkt in de jurisprudentie van de Hoge Raad over de reikwijdte van het beklag tegen beslag, zoals geregeld in artikel 552a Sv (zie daarover paragraaf Io.3).

\subsection{Op zoek naar evenwicht}

De in artikel $98 \mathrm{~Sv}$ neergelegde bescherming van het verschoningsrecht tegen inbreuken daarop door beslag en doorzoeking is in de kern in vele tientallen jaren nauwelijks veranderd. ${ }^{124}$ De positie van de verschoningsgerechtigde in de maatschappij is echter een heel andere dan kort na de Tweede Wereldoorlog, toen van de arts, de advocaat, de notaris en de dominee nog werd gezegd dat zij bekleders waren van nobilia officia en dat de rechter daarom meestal wel op hun kompas zou kunnen varen. ${ }^{125} \mathrm{Er}$ is echter zowel in Nederland als daarbuiten volop oog ontstaan voor de kwetsbaarheid van de verschoningsgerechtigde in relatie tot zijn soms criminele cliënt, ${ }^{226}$ voor het misbruik dat de laatste van de bijzondere positie van de verschoningsgerechtigde kan maken en voor het feit dat ook de verschoningsgerechtigde niet altijd bestand is tegen de verleiding van soms ernstige criminaliteit. Een en ander heeft ertoe geleid dat de bijzondere positie van de verschoningsgerechtigde in de strafrechtspleging ter discussie is komen te staan. Gedachten over het toestaan van inbreuken op het verschoningsrecht roepen een krachtig tegengeluid op, ook

I24 Waar de wet werd aangepast aan de techniek - te denken valt aan de doorzoeking ter vastlegging van gegevens - werd art. $98 \mathrm{~Sv}$ van toepassing verklaard (art. I25i Sv) of werd een voorziening getroffen die op soortgelijke wijze recht doet aan de bijzondere positie van de verschoningsgerechtigde in het recht (art. I25l Sv).

I25 D. Hazewinkel-Suringa, De doolhof van het beroepsgeheim, Haarlem: H.D. Tjeenk Willink \& Zoon I959, p. I79.

I26 'Omdat notarissen en advocaten behoren tot een categorie van dienstverleners waar personen in bepaalde situaties gebruik van moeten maken, omdat dat wettelijk is voorgeschreven of omdat dat vanwege de benodigde expertise moeilijk anders kan, vormen ze een risicogroep; ze lopen de kans met personen in aanraking te komen die hen voor criminele doeleinden willen gebruiken. Vanwege specialistische kennis, witwasmogelijkheden (derdengeldenrekening) of bepaalde exclusieve bevoegdheden kunnen ze criminelen van nut zijn', aldus de Monitor georganiseerde criminaliteit (WODC), 2013. Zie ook Money Laundering and Terrorist Financing Vulnerabilities of Legal Professionals (2013), rapport van de Financial Action Task Force (FATF), te raadplegen via <www. fatf-gafi.org>. 
van buiten de betrokken beroepsgroepen. ${ }^{127}$ Niettemin wordt ook door de beroepsgroep zelf soms opvallend luchthartig omgesprongen met de aan het verschoningsrecht ten grondslag liggende geheimhoudingsplicht. Zo zag het VUmc er geen been in Eyeworks buiten medeweten van de patiënten te laten filmen met een verborgen camera op de afdeling Spoedeisende hulp..$^{128}$

De maatschappelijke ontwikkelingen lijken te gaan in de richting van een nieuw evenwicht tussen de noodzaak van de waarheidsvinding in het strafrecht en het belang van het verschoningsrecht van de professionele verschoningsgerechtigde als arts, advocaat en notaris. De weerslag daarvan is te vinden in de genuanceerde rechtspraak over het verschoningsrecht, die inbreuken mogelijk maakt op het verschoningsrecht die niet in de wet zijn voorzien, maar tegelijkertijd ook waarborgen schept die de wet niet kent. Artikel $98 \mathrm{~Sv}$ biedt daardoor al lang geen getrouw beeld meer van de juridische werkelijkheid rond het verschoningsrecht. De huidige stand van zaken rond de bescherming van het verschoningsrecht moet daarom niet in de wet, maar in de rechtspraak worden gezocht.

\subsection{Zeer uitzonderlijke omstandigheden}

In $1986^{\text {129 }}$ besliste de Hoge Raad dat, hoewel de bewoordingen van artikel $98 \mathrm{~Sv}$ daarvoor geen houvast bieden, het mogelijk is om het verschoningsrecht te doorbreken indien zeer uitzonderlijke omstandigheden daartoe aanleiding geven. ${ }^{13^{\circ}}$ Het belang dat de waarheid aan het licht komt ook ten aanzien van datgene waarvan de wetenschap aan de functionele verschoningsgerechtigde als zodanig is toevertrouwd, prevaleert in dat geval boven het belang dat ten grondslag ligt aan het verschoningsrecht. Van belang is dat alleen de waarheidsvinding in geval van zeer uitzonderlijke omstandigheden reden kan geven tot doorbreking van het verschoningsrecht, zo blijkt uit de rechtspraak. ${ }^{\mathrm{II}}$ Beslag en doorzoeking met het enige doel de hand te

I27 Zie bijvoorbeeld M.J. Borgers en T. Kooijmans, 'Een lichtzinnig voorstel omtrent het verschoningsrecht in strafzaken', DD 2012, 56, p. 59I e.v. en de reactie van (onder meer) de Raad voor de Rechtspraak op de doorbreking van het medisch beroepsgeheim in het wetsvoorstel Forensische zorg (via <www.rechtspraak.nl/Organisatie/Raad-Voor-De-rechtspraak/Wetgevingsadvisering>).

I28 Ook het bericht dat alle ziekenhuizen in de Amsterdamse regio de politie gaan helpen, roept ondanks de waarborg die de toetsingscommissies in de ziekenhuizen lijkt te bieden vragen op. (zie <www.nrc.nl/nieuws/2013/07/03>). De medische staf op de spoedeisende hulp gaat de verwonde patiënt vragen hoe laat deze is toegetakeld, waar, en met welk wapen. De ziekenhuizen verzamelen die informatie, ontdoen die van persoonsgegevens, en spelen de informatie door aan de politie en aan de Gemeente Amsterdam.

I29 HR I4 oktober I986, NJ I987, 490.

I30 Zie hierover ook J. Legemaate, 'Beperken van het medisch beroepsgeheim?', NJB 20II, 2097, p. 2784 e.v.

I3I In vaste rechtspraak spreekt de Hoge Raad van 'de waarheid aan het licht komen' als grond voor beslag. Dat doet vermoeden dat de later aan art. 94 lid I Sv toegevoegde beslaggrond 'het aantonen van wederrechtelijk verkregen voordeel' ondanks zeer uitzonderlijke omstandigheden de doorzoeking en het beslag niet kan rechtvaardigen. Tijdens het strafrechtelijk financieel onderzoek ligt dit anders: art. I26d Sv. 
leggen op geschriften en gegevens anders dan corpora en instrumenta in verband met verbeurdverklaring of onttrekking aan het verkeer is dus niet mogelijk..$^{132}$

Het enkele feit dat de verschoningsgerechtigde zelf wordt verdacht van een strafbaar feit is geen 'zeer uitzonderlijke omstandigheid' op grond waarvan het verschoningsrecht mag worden doorbroken. ${ }^{133}$ Dat kan anders zijn bij verdenking van een ernstig strafbaar feit, zoals het vormen van een crimineel samenwerkingsverband door de advocaat met zijn cliënt. ${ }^{134}$ In een dergelijk geval dienen onder omstandigheden het verschoningsrecht en de daarmee samenhangende beperkingen van de uitoefening van de beslag- en doorzoekingsbevoegdheden te wijken voor het belang van de strafvordering. Niettemin mag dan de inbreuk op het verschoningsrecht niet verder gaan dan strikt nodig is voor het aan het licht brengen van de waarheid van het desbetreffende strafbare feit; daarbij moet zorg worden betracht om te voorkomen dat de belangen van andere cliënten van de advocaat dan de cliënten die betrokken zijn bij de strafbare feiten waarvan de advocaat wordt verdacht, onevenredig zouden worden getroffen. ${ }^{135}$ De rechter-commissaris speelt hierbij een sleutelrol (zie paragraaf 9.4).

Vergelijkbaar met het hiervoor genoemde geval van de advocaat die verdacht wordt van een ernstig strafbaar feit is de casus waarin de verdenking een door de verschoningsgerechtigde jegens een patiënt gepleegd delict betreft. Het verschoningsrecht van de arts kan in dit geval worden doorbroken, nu patiënten in het algemeen erop moeten kunnen vertrouwen dat bij een ernstig vermoeden van verwijtbaar ondeskundig handelen van een arts de gegevens die in het medisch dossier zijn vastgelegd, ${ }^{136}$ voor onderzoek door de justitiële autoriteiten beschikbaar zijn. ${ }^{137}$ Bovendien mag het verschoningsrecht er niet toe dienen om de waarheid te bemantelen indien het gaat om de verdenking van een jegens de patiënt gepleegd delict, aldus de Hoge Raad. ${ }^{138}$

Er kan ook sprake zijn van zeer uitzonderlijke omstandigheden die een inbreuk op het verschoningsrecht rechtvaardigen wanneer de verschoningsgerechtigde niet verdacht wordt van een strafbaar feit, maar ernstige strafbare feiten worden vermoed ten aanzien van aan de zorg van de verschoningsgerechtigde toevertrouwde personen. ${ }^{\mathrm{I} 9}$ Een voorbeeld van deze categorie biedt de zaak van beslag

I32 In de praktijk zullen de verschillende beslaggronden, zeker aan het begin van het onderzoek, vaak nauwelijks van elkaar te onderscheiden zijn.

I33 Vaste rechtspraak, bijvoorbeeld HR I8 januari 2005, LJN AR5009.

I34 In HR I8 juni 20I3, LJN CA33I4, was sprake van beslag in verband met de verdenking jegens een notaris van o.m. het medeplegen van witwassen en het medeplegen van valsheid in geschrift met betrekking tot authentieke akten. Zie over deze materie ook de annotatie van Mevis bij Rb. Utrecht 30 juli20I2, LJN BN8673, NJ 20II, 443.

I35 HR 30 november 1999 , NJ 2002, 438, m.nt. YB, HR I2 februari 2002, NJ 2002, 439 en HR I4 juni 2005, NJ 2005, 353.

I36 De Hoge Raad wijst erop dat het hierbij bovendien gaat om gegevens met betrekking tot de medische behandeling die veelal verplicht in het medisch dossier zijn vastgelegd.

I37 HR 2I oktober 2008, LJN BD78I7, NJ 2008, 630, m.nt. J. Legemaate (Erasmus MC).

I38 HR 26 mei 2009, LJN BG5979 NJ 2009, 263, m.nt. J. Legemate (LUMC).

I39 Ook de zaak Savanna valt in deze categorie: HR 9 mei 2006, LJN AV2386, NJ 2006, 622, m.nt. J. de Boer, NJCM-bull. 2006, p. II 28 e.v., m.nt. M.R. Bruning. 
op NAW-gegeven $\mathrm{s}^{\mathrm{I} 40}$ onder de verschoningsgerechtigde psychiater van twee in een kinderpsychiatrische kliniek opgenomen jongens, die werden verdacht van herhaald seksueel misbruik van een eveneens in de kliniek opgenomen jongere jongen. Uit deze zaak blijkt dat factoren als (a) de aard van de gevraagde gegevens, (b) de omstandigheid dat die gegevens niet op andere wijze konden worden verkregen, (c) de omstandigheid dat er sprake is van ernstige delicten en (d) dat het in deze zaak gaat om feiten die jongens (patiënten) in een door de klagers gedreven psychiatrisch centrum zouden hebben begaan tegenover eveneens opgenomen en dus aan hun zorg toevertrouwde patiënten, voldoende kunnen zijn om te concluderen tot zeer uitzonderlijke omstandigheden.

De vraag of er sprake is van zeer uitzonderlijke omstandigheden moet in voorkomende gevallen worden beantwoord tegen de achtergrond van de uit de artikelen 2 en 3 EVRM voortvloeiende verplichting van de Staat tot het doen van een effectief en onafhankelijk onderzoek naar strafbare feiten die een inbreuk maken op deze verdragsrechten. Onder omstandigheden kunnen deze positieve verplichtingen tot bescherming van het leven en tot het tegengaan van 'ill treatment' gewicht in de schaal leggen bij de beslissing dat een inbreuk op het verschoningsrecht moet worden gemaakt. ${ }^{\mathrm{I} 4 \mathrm{I}}$

In de Nederlandse rechtspraak wordt benadrukt dat niet in een algemene regel is samen te vatten wanneer er sprake is van zeer uitzonderlijke omstandigheden. ${ }^{\mathrm{I} 22}$ In elk individueel geval dient een zorgvuldige weging van factoren plaats te vinden, waarbij conform de wettelijke regeling de eerbiediging van het verschoningsrecht uitgangspunt dient te zijn en met zorg moet worden nagegaan of er sprake is van daadwerkelijk 'zeer uitzonderlijke omstandigheden' die een inbreuk op het verschoningsrecht kunnen rechtvaardigen. In deze context is zwaarwegend of er niet een minder ingrijpend alternatief voorhanden is dan doorbreking van het verschoningsrecht. Procedureel sluitstuk van deze afweging zijn de zware motiveringseisen die zijn verbonden aan de vaststelling van de zeer uitzonderlijke omstandigheden. ${ }^{143}$

I40 Naam-, adres- en woonplaatsgegevens.

I4I HR 5 juli 20II, LJN BP6I4I, NJ 20II, 4I6, m.nt. J. Legemaate (met betrekking tot de positieve verplichting uit art. 2 EVRM). Over dit arrest: F. Vellinga-Schootstra, 'Positieve verplichtingen en het verschoningsrecht', DD 20II, 72, p. I027 e.v. Deze categorie gevallen waarin sprake kan zijn van zeer uitzonderlijke omstandigheden zal niet steeds te onderscheiden zijn van de andere drie categorieën. Zie hierover ook F. Vellinga-Schootstra en W.H. Vellinga, 'Positive obligations' en het Nederlandse straf(proces)recht, Deventer: Kluwer 2008. Het belang van de positieve verdragsverplichtingen bij de vaststelling van de zeer uitzonderlijke omstandigheden blijkt ook uit HR I4 mei 2013, LJN BZ9943, waarin het ging om beslag op videobanden van speltherapie in een geval van vermoed seksueel misbruik van een kind door de vader. De Hoge Raad verwierp het cassatieberoep onder verwijzing naar de conclusie van de advocaat-generaal, die (in punt 58 e.v.) in het kader van de beoordeling van de vaststelling van de zeer uitzonderlijke omstandigheden het belang onderstreepte van de uit art. 3 en 8 EVRM voortvloeiende verplichting 'to enact criminal law provisions effectively punishing sexual abuse of children and to apply them in practice through effective investigation and prosecution'.

I42 Bijvoorbeeld in HR 28 februari 20I2, LJN BU6o88, NJ 20I2, 537, m.nt. J. Legemaate.

I43 HR 9 mei 2006, LJN AV2386, NJ 2006, 622, m.nt. J. de Boer, NJCM-bull. 2006, p. II28 e.v., m.nt. M.R. Bruning (Savanna). 
De rechtspraak van de Hoge Raad sluit aan bij die van het EHRM, in die zin dat ook volgens rechtspraak van dit laatste college het legal en medical professional privilege niet absoluut is. ${ }^{144}$ Onder bepaalde omstandigheden moet het wijken voor andere, hogere belangen, zoals het belang der waarheidsvinding, ${ }^{145}$ het tegengaan van witwassen $^{\text {146 }}$ en van (de financiering van) terrorisme. ${ }^{147}$ Ook tegen de achtergrond van artikel 8 EVRM is het daarbij van belang dat een minder ingrijpende wijze van verkrijging van de door justitie verlangde stukken en gegevens wordt benut en dat de inbreuk op de persoonlijke levenssfeer zo beperkt mogelijk blijft. Dat het daarvoor soms nodig is enige druk op de justitiële autoriteiten uit te oefenen blijkt in de Nederlandse rechtspraak bijvoorbeeld uit een beschikking van de Hoge Raad in een zaak waarin het ging om een vordering tot verstrekken van identiteitsgegevens van patiënten die op een bepaalde dag het laboratorium van een ziekenhuis hadden bezocht. ${ }^{148}$ In deze zaak werd aanvankelijk bekendmaking gevorderd van de identiteitsgegevens van alle personen die zich op een bepaalde dag tussen 7 en II uur hadden gemeld bij het ziekenhuislaboratorium. Na bezwaren van het ziekenhuis werd de vordering teruggebracht tot de gegevens van de personen die daar waren geweest tussen 8.15 en 9.30 uur terwijl tijdens de behandeling van de bezwaren van het ziekenhuis in de raadkamerprocedure voldoende bleek te zijn de bekendmaking van de gegevens van één bepaalde persoon die gedurende de genoemde tijden het laboratorium zou hebben bezocht. Vasthoudendheid en een kritische opstelling van de rechter(-commissaris) kan dus leiden tot een geringere schending van de persoonlijke levenssfeer en is daarom van groot belang.

\subsection{De gang van zaken bij beslag en doorzoeking}

Het verrichten van een doorzoeking bij de verschoningsgerechtigde is in beginsel de taak van de rechter-commissaris, al dan niet op vordering van de officier van justitie (artikel I04 jo. artikel $97 \mathrm{~Sv}$ ). Kan het optreden van de rechter-commissaris

I44 Voor het medisch beroepsgeheim bijvoorbeeld EHRM 25 februari I997, nr. 22009/93, NJ I999, 5I6, m.nt. Kn., NJCM-bull. I997, p. 733, m.nt. A.C. Hendriks (Z. t. Finland): 'At the same time, the Court accepts that the interests of a patient and the community as a whole in protecting the confidentiality of medical data may be outweighed by the interest in investigation and prosecution of crime and in the publicity of court proceedings (...), where such interests are shown to be of even greater importance.' (par. 97).

I45 Zie Z. t. Finland, genoemd in de vorige noot.

I46 Daarom draaide het in EHRM 6 december 20I2, nr. I2323/II, EHRC 2013/9I, m.nt. F.P. Ölçer (Michaud t. Frankrijk): 'It is true that, as previously indicated, legal professional privilege is of great importance for both the lawyer and his client and for the proper administration of justice. It is without a doubt one of the fundamental principles on which the administration of justice in a democratic society is based. It is not, however, inviolable (...). Its importance should also be weighed against that attached by the member States to combating the laundering of the proceeds of crime, which are likely to be used to finance criminal activities linked to drug trafficking, for example, or international terrorism (see Grifhorst v. France, no. 28336/02, § 93, 26 February 2009).'

I47 Vgl. EHRM 5 juli 200I, nr. 38321/97, EHRC 2001/62, m.nt. H.L. Janssen (Erdem t. Duitsland).

I48 In de Savanna-zaak (HR 9 mei 2006, LJN AV2386, NJ 2006, 622, m.nt. J. de Boer, NJCM-bull. 2006, p. II 28 e.v., m.nt. M.R. Bruning) leidde de kritische toetsing door de Hoge Raad tot een veel minder omvangrijk beslag dan aanvankelijk door justitie was beoogd. 
niet worden afgewacht en is er sprake van dringende noodzakelijkheid, dan kan naar de letter van de wet de officier van justitie en in geval van grote spoed zelfs de hulpofficier ${ }^{149}$ tot doorzoeking overgaan (artikel 97 Sv). ${ }^{150}$ Zowel de officier als de hulpofficier heeft daartoe de machtiging van de rechter-commissaris nodig. Uit artikel 8 lid 2 EVRM vloeit de door het EHRM onlangs weer benadrukte ${ }^{15 \mathrm{I}}$ en in de praktijk in Nederland menigmaal verwaarloosde eis voort dat de machtiging - als garantie tegen een onderzoek dat de grenzen van de proportionaliteit overschrijdtvoldoende concreet aangeeft tot welke handelingen de machtiging strekt. Daarbij kan als vuistregel gelden: hoe gevoeliger de doorzoeking, des te exacter moet in de machtiging worden omschreven naar welke zaken mag worden gezocht..$^{152}$ In de rechtspraak is een ander aspect van het vereiste van proportionaliteit benadrukt: de zoeking 'dient te geschieden op zodanige wijze en onder zodanige omstandigheden dat de kans dat gegevens waarvan de wetenschap de verschoningsgerechtigde in diens hoedanigheid zijn toevertrouwd ter kennis van derden zouden kunnen komen, zo klein mogelijk is.' ${ }^{153}$

De wet vereist dus niet dat de doorzoeking bij de verschoningsgerechtigde door de rechter-commissaris zelf wordt verricht. Gezien het belang dat het EHRM toekent aan de betrokkenheid van de rechter bij beslag en doorzoeking in precaire gevallen $^{154}$ is het echter wel verstandig dat dergelijke doorzoekingen zo veel mogelijk door de rechter-commissaris ter hand worden genomen. Een centrale rol van de rechter-commissaris is in de Nederlandse rechtspraak wel vereist wanneer de zoeking een verdere strekking heeft dan het onderzoek naar schriftelijke corpora en instrumenta (die immers per definitie niet onder het verschoningsrecht vallen), en er sprake is van zeer uitzonderlijke omstandigheden op grond waarvan doorbreking van het verschoningsrecht gerechtvaardigd is. De doorzoeking moet in dit geval door de rechter-commissaris persoonlijk worden verricht. ${ }^{155}$

I49 Zo ver zou het met de huidige communicatiemiddelen niet moeten komen; ook in de wetsgeschiedenis is benadrukt dat de doorzoeking bij de verschoningsgerechtigde door de officier van justitie persoonlijk wordt verricht.

I50 In deze moet worden gehandeld conform de Aanwijzing gevoelige zaken; dat betekent dat de toepassing van dwangmiddelen slechts geschiedt na overleg met de parketleiding, die het College van procureurs-generaal over de zaak informeert, aldus de Aanwijzing toepassing opsporingsbevoegdheden en dwangmiddelen tegen advocaten (20IIAo03), 7 maart 20II, Stcrt. 20II, 498I; voor medische zaken geldt de Aanwijzing feitenonderzoek/strafrechtelijk onderzoek en vervolging in medische zaken (2010A022gh), I2 september 20I0. Beide aanwijzingen zijn ook te raadplegen via <www.om.nl/organisatie/beleidsregels $>$.

I5I EHRM I8 april 20I3, nr. 264I9/IO (Saint Paul Luxembourg S.A. t. Luxembourg) (doorzoeking en bronbescherming journalist).

I52 Handboek Strafzaken, hfdst. I4 'Doorzoeking'. In Duitsland wordt dit vereiste veel strenger getoetst dan in Nederland; zie bijvoorbeeld BVerfG, 2 BvR I940/05, Beschluss I7 maart 2009.

I53 HR 20 juni I988, NJ I989, 2I3. De Hoge Raad overweegt vervolgens dat de rechtbank dit tot uitdrukking heeft gebracht in onder meer het vereiste 'dat het zoeken gericht dient te geschieden, dat wil zeggen met mededeling vooraf van een duidelijke en concrete omschrijving van de aard van de gezochte bescheiden'.

I54 EHRM I4 september 20I0, nr. 38224/03, NJ 20II, 230, m.nt. E.J. Dommering en T.M. Schalken (Sanoma t. Nederland), EHRM 22 november 2012, nr. 39315/06, EHRC 2013/36, m.nt. S.P. Poppelaars (Telegraaf Media Nederland Landelijke Media B.V. e.a.).

I55 Dit vereiste vloeit niet voort uit de wet, maar uit de rechtspraak: HR 30 november I999, NJ 2002, 438 , m.nt. YB. 
Zowel wanneer de doorzoeking zich beperkt tot de schriftelijke corpora en instrumenta van het strafbare feit als wanneer bij aanwezigheid van zeer uitzonderlijke omstandigheden het verschoningsrecht moet worden doorbroken is de aanwezigheid bij de doorzoeking van een gezaghebbend vertegenwoordiger van de beroepsgroep, zoals de (plaatsvervangend) deken van de Orde van Advocaten, van belang. ${ }^{156}$ De Hoge Raad eist weliswaar strikt genomen geen aanwezigheid van de vertegenwoordiger van de beroepsgroep, ${ }^{157}$ maar spreekt van 'overleg' met deze functionaris. Praktisch gesproken zal dit in de regel betekenen dat de waarnemer bij de doorzoeking aanwezig is. Het EHRM noemt in vaste rechtspraak de aanwezigheid van een waarnemer van de beroepsgroep als een van de factoren die bepalend zijn voor de vraag of er in het kader van de vaststelling van de noodzakelijkheid van de inbreuk op artikel 8 EVRM in een democratische samenleving, sprake is van proportionaliteit. ${ }^{\mathrm{I} 8}$

Stelt de verschoningsgerechtigde bij wie de doorzoeking plaatsvindt dat de brieven of geschriften waarnaar de belangstelling van justitie uitgaat geen voorwerp van het strafbare feit uitmaken en evenmin tot het begaan daarvan hebben gediend, dan moet dit oordeel door de doorzoekende autoriteit worden gerespecteerd. Dit is alleen anders wanneer er redelijkerwijs geen twijfel over kan bestaan dat dit standpunt onjuist is. ${ }^{59}$ Het oordeel van de vertegenwoordiger van de beroepsgroep kan hierbij een belangrijke rol spelen. Gaat het echter om de vraag of er sprake is van zeer uitzonderlijke omstandigheden die rechtvaardigen dat ten behoeve van de waarheidsvinding beslag wordt gelegd op stukken die onder het verschoningsrecht vallen, dan is het niet de verschoningsgerechtigde die de in beginsel doorslaggevende stem heeft en is evenmin het oordeel van de vertegenwoordiger van de

I56 De Aanwijzing toepassing dwangmiddelen gaat uit van aanwezigheid van de deken; in het voetspoor van de aanwijzing schrijft ook de Handleiding voor de deken ter waarborging van de geheimhoudingsplicht en het verschoningsrecht van advocaten bij extern onderzoek, maart 2013 , te raadplegen via $<w w w . a d v o c a t e n o r d e . n l>$, deze aanwezigheid voor. In beide documenten wordt de voorbereiding van de doorzoeking stapsgewijs besproken. Voor de advocaat: Handleiding voor advocaten ter waarborging van de geheimhoudingsplicht en het verschoningsrecht van advocaten bij extern onderzoek, maart 2013, eveneens via de vermelde site te raadplegen. Ten aanzien van de notariële beroepsgroep (Ringvoorzitter): Handleiding voor de doorzoeking van een notariskantoor van de Koninklijke Notariële Beroepsorganisatie, 23 maart 2oro; zie over deze materie ook P.C. van Es, C.A. Kraan e.a., Meer spreken, minder zwijgen? Over geheimhouding, informatieplicht en verschoningsrecht van de notaris, Den Haag: Sdu Uitgevers 2007. Voor het justitieel onderzoek bij artsen is de KNMG Handreiking Beroepsgeheim en justitie/politie (I6 februari 20I2) opgesteld. Uitgebreid hierover W.L.J.M. Duijst-Heesters, Boeven in het ziekenhuis, ze herziene druk, Den Haag: Sdu Uitgevers 2005.

I57 In de gepubliceerde rechtspraak gaat het meestal om de deken van de Orde van Advocaten.

I58 Onder meer EHRM 27 september 2005, nr. 50882/99 (Sallinen e.a. t. Finland), EHRM I6 oktober 2007, nr. 74336/or (Wieser and Bicos Beteiligungen GMBH t. Oostenrijk) en EHRM 22 mei 2008, nr. 65755/or (Iliya Stefanov t. Bulgarije); in deze en andere EHRM-rechtspraak wordt gesproken over de eis 'that the search was carried out in the presence of an independent observer'. Zie uitgebreider hierover Handboek Strafzaken, hfdst. I4.7 en de daar genoemde literatuur (onder meer T. Spronken, Verdediging, Deventer: Gouda Quint 200I).

I59 Vaste rechtspraak, onder meer HR I2 februari 2002, NJ 2002, 439, m.nt. YB onder NJ 2002, 438 en 440, HR I8 januari 2005, LJN AR5009 (Notarisklerk), alsmede HR I3 januari 2006, RvdW 2006, 82 (verschoningsrecht notaris, civiel). HR 2 juli 20I3, ECLI:NL:HR:20I3:CA0434 benadrukt de vereiste degelijkheid van het onderzoek dat aan het oordeel van de rechter-commissaris ten grondslag ligt. 
beroepsgroep beslissend. De rechter-commissaris beslist in dit geval over de inbeslagneming op eigen kompas, bij voorkeur wel na het advies te hebben ingewonnen van de vertegenwoordiger van de beroepsgroep. ${ }^{160}$ Voor de vaststelling van de zeer uitzonderlijke omstandigheden gelden zware motiveringseisen. De rechter, oordelend in de artikel 552a Sv-procedure dan wel in de hoofdzaak, dient de vaststelling van de zeer uitzonderlijke omstandigheden in volle omvang te toetsen. ${ }^{\mathrm{Ir}}$ In cassatie evenwel kan dit oordeel dikwijls maar beperkt worden getoetst, nu het meestal is verweven met de waardering van omstandigheden van feitelijke aard.

Wanneer het voor het zeker stellen van de stukken niet noodzakelijk is dat een doorzoeking bij de verschoningsgerechtigde wordt verricht, dient uit het oogpunt van proportionaliteit en subsidiariteit te worden volstaan met een tot de verschoningsgerechtigde gericht bevel tot uitlevering ter inbeslagneming. Artikel $96 \mathrm{~Sv}$ bevat daartoe - evenals artikel ${ }_{0} 5 \mathrm{~Sv}$ - de bevoegdheid voor zover het gaat om voorwerpen, artikel I26nf Sv voor 'gevoelige gegevens'. Voor toepassing van deze laatste bevoegdheid is niet relevant of de gegevens traditioneel op schrift zijn gesteld, dan wel digitaal zijn opgeslagen op gegevensdragers (harde schijf van een computer), usb-sticks of dvd's. Artikel I26nf Sv bevat dus een techniek-onafhankelijke regeling. De professionele verschoningsgerechtigde is niet verplicht om gehoor te geven aan de vordering voor zover de uitlevering met zijn plicht tot geheimhouding in strijd zou zijn, ongeacht of het bevel wordt uitgevaardigd uit hoofde van artikel 96a Sv dan wel artikel I26nf Sv. Opvallend is dat voor een bevel aan de verschoningsgerechtigde als bedoeld in artikel 96a Sv niet, en voor het bevel op grond van artikel I26nf Sv wel een voorafgaande machtiging van de rechter-commissaris is vereist. De regeling van artikel 96a Sv is in dit opzicht, zeker in het perspectief van artikel 8 EVRM in gevallen waarin deze wordt toegepast op verschoningsgerechtigden, onder de maat.

Zowel bij beslag ter gelegenheid van een doorzoeking als bij beslag na een bevel tot uitlevering is het in Nederland ${ }^{162}$ gebruik dat bij verschil van mening tussen de beslagleggende autoriteit enerzijds en de verschoningsgerechtigde dan wel de vertegenwoordiger van de beroepsgroep anderzijds over vatbaarheid voor beslag van de geschriften en gegevens in verband met het verschoningsrecht, de gegevens waarom het gaat in beslag genomen worden en in een verzegelde enveloppe of een doos worden gesloten. ${ }^{16_{3}}$ Met de verschoningsgerechtigde wordt vervolgens een termijn afgesproken waarbinnen deze een klaagschrift tegen de inbeslagneming als bedoeld in artikel $552 \mathrm{a}$ Sv kan indienen opdat de rechter zich kan uitlaten over de rechtmatigheid van het beslag. ${ }^{64}$ Wordt van deze gelegen heid geen gebruik gemaakt

I6o Vaste rechtspraak, onder meer HR I8 juni 2002, NJ 2003, 62I en HR 2 maart 20Io, LJN BJ9262. Voor zover nodig mag daartoe door de rechter-commissaris van de desbetreffende stukken kennis worden genomen (HR 2 juli 2013, ECLI:NL:HR:2013:CA0434).

I6I HR I5 mei 2007, LJN BAo49I, NJ 2007, 300.

I62 En, naar ik heb begrepen, in Frankrijk, op basis van art. $56 \mathrm{CPP}$.

I63 Deze procedure wordt met name, maar niet uitsluitend, toegepast wanneer het verschoningsrecht in het geding is: HR I2 december 20I0, LJN BLo666.

I64 In verband met de voortgang van het onderzoek is deze termijn in de regel aanzienlijk korter dan de wettelijke termijn. 
of wordt het beklag ongegrond verklaard, dan worden de stukken/gegevens na verstrijken van de termijn dan wel na het onherroepelijk worden van de beschikking aan het Openbaar Ministerie ter hand gesteld. Wordt wel een klaagschrift ingediend en wordt het beklag (onherroepelijk) gegrond bevonden dan gaan de stukken terug naar de verschoningsgerechtigde. Op de gesloten enveloppe-procedure kom ik terug in paragraaf 10.5 .

\subsection{De doorzoeking tijdens het strafrechtelijk financieel onderzoek}

Artikel I26d Sv verklaart artikel 98 Sv van toepassing op de doorzoeking tijdens het strafrechtelijk financieel onderzoek (s.f.o.). De positie van de verschoningsgerechtigde bij beslag en doorzoeking is daarmee vergelijkbaar met die buiten het s.f.o. Maar omdat de doorzoeking tijdens het s.f.o. met name gericht is op het aantonen van wederrechtelijk genoten voordeel, bepaalt artikel I26d Sv dat dit onderzoek zich mede uitstrekt tot bescheiden of geschriften die kunnen dienen om wederrechtelijk voordeel aan te tonen dat is verkregen door degene tegen wie het (strafrechtelijk financieel) onderzoek is gericht. Daardoor staat buiten kijf dat de doorzoeking zich niet behoeft te beperken tot papieren die het voorwerp van het strafbare feit uitmaken of tot het begaan daarvan hebben gediend, de categorie die in artikel $98 \mathrm{lid} 2 \mathrm{~Sv}$ wordt genoemd. Zeer uitzonderlijke omstandigheden, die bij de doorzoeking buiten het s.f.o nodig zijn om ten behoeve van de waarheidsvinding ${ }^{165}$ te kunnen zoeken naar andere brieven en geschriften dan corpora en instrumenta, zijn voor de doorzoeking tijdens het s.f.o. dus niet vereist. ${ }^{166}$

\subsection{Beslag en doorzoeking in de digitale omgeving; cloudcomputing}

Papieren dossiers behoren vrijwel tot het verleden. De handgeschreven patiëntenkaart begint gaandeweg een zeldzaamheid te worden, in de praktijk van de verschillende verschoningsgerechtigden staan zo langzamerhand digitaal vastgelegde gegevens centraal. Deze gegevens zijn opgeslagen op harde schijven van computers en op andere gegevensdragers in het kantoor van de verschoningsgerechtigde, maar bevinden zich in toenemende mate ook 'in de cloud', op verschillende computers overal ter wereld, ${ }^{167}$ opgeslagen via cloud-diensten als Google drive, Dropbox en Sugar Sync. ${ }^{168}$ Dat roept nieuwe vragen op voor de opsporing. ${ }^{169}$

I65 Zie art. 94 lid I Sv.

I66 Het is de vraag of de wetgever dit in volle omvang onder ogen heeft gezien. Zie hierover ook R.M. Vennix, Boefen beslag, Nijmegen: Ars Aequi Libri 1998, p. I59 e.v.

I67 Zie hierover B.J. Koops e.a., Misdaad en opsporing in de wolken, Den Haag: WODC 20I2, volledige tekst te raadplegen via <www.wodc.nl/onderzoeksdatabase/cloud-computing >.

I68 De vraag die hier noodgedwongen blijft liggen is in hoeverre het verantwoord is dat de verschoningsgerechtigde gegevens opslaat in de soms slecht beveiligde cloud. Bedrijven die clouddiensten aanbieden voor o.m. geheimhouders schieten als paddenstoelen uit de grond, maar lang niet altijd blijkt de beveiliging deugdelijk te zijn (zie bijvoorbeeld <www.spiegel.de/thema/ cloud_computing >). Bovendien is het niet altijd duidelijk wie zeggenschap heeft over in de cloud opgeslagen gegevens.

I69 Waarop deels antwoord wordt gegeven in het wetsvoorstel Computercriminaliteit III van 2 mei 2013. 
Vooropgesteld moet worden dat artikel ${ }_{2} 25 \mathrm{l} \mathrm{Sv}$ de verschoningsgerechtigde in de digitale wereld dezelfde bescherming beoogt te bieden als artikel $98 \mathrm{~Sv} .{ }^{170}$ Een soortgelijke strekking heeft de laatste volzin van artikel I25i Sv, dat de doorzoeking ter vastlegging van gegevens regelt. Een eerste probleem van de digitalisering van de praktijk van de verschoningsgerechtigde is dat bij beslag op gegevens filtering op de plaats van de doorzoeking lastiger is dan bij zoeken in dossierkasten het geval zou zijn. Ook wanneer bij het zoeken naar bepaalde gegevens de goede opsporingssoftware wordt gebruikt, worden dikwijls veel meer gegevens in beslag genomen dan daadwerkelijk relevant zijn voor het onderzoek. Soms wordt een complete image gemaakt van de het te doorzoeken geautomatiseerd werk, of wordt de computer in beslag genomen en meegenomen voor onderzoek. Pas in het kabinet van de rechter-commissaris wordt dan de (tijdrovende) selectie van gegevens ter hand genomen. ${ }^{17 \mathrm{I}}$ Tegen de achtergrond van de waarborgfunctie van de voorschriften betreffende beslag en doorzoeking bij de verschoningsgerechtigde is dit zorgelijk. Niet voor niets beklemtoont de Hoge Raad dat gewaarborgd dient te zijn dat de inbeslaggenomen gegevensdragers zullen worden onderzocht op een wijze waarbij het verschoningsrecht van de advocaat niet in het gedrang komt. ${ }^{172}$ Eerder benadrukte ook het EHRM tegen de achtergrond van artikel 8 EVRM en het legal professional privilege van de advocaat waakzaamheid op dit punt. ${ }^{173}$

Een ander probleem voor de opsporing die betrekking heeft op de cloud-opslag van gegevens, is de vraag of en in hoeverre de Nederlandse opsporingsambtenaar toegang heeft tot de gegevens die in de cloud zijn opgeslagen. Artikel I25j Sv bepaalt dat, in geval van een doorzoeking, vanaf de plaats waar de doorzoeking plaatsvindt in een elders aanwezig geautomatiseerd werk onderzoek kan worden gedaan naar in dat werk opgeslagen gegevens die kunnen dienen om de waarheid aan de dag te brengen (netwerkzoeking). ${ }^{174}$ De koppeling van de bevoegdheid tot het doen van onderzoek in een geautomatiseerd werk aan die tot het verrichten van doorzoeking heeft de wetgever bewust tot stand gebracht. In deze verbinding ligt de waarborg voor de burger besloten dat justitie niet - zoals bij de telefoontap - gedurende enige tijd buiten zijn medeweten om gegevens kan onderscheppen. Daarmee is op basis van de huidige wetgeving de 'onlinedoorzoeking' die in Duitsland zoveel stof deed opwaaien $^{175}$ formeel niet mogelijk.

I70 De bedoeling van de wetgever komt in de tekst van de wet niet geheel tot zijn recht: zie F. Vellinga-Schootstra, Handboek Strafzaken, par. I4.13.4.

I7I Relevant in dit verband is HR I9 mei 2009, LJN BH7284 (de zaak betrof digitale en papieren bestanden): 'De opvatting dat de zorgvuldigheid waarmee de inbeslagneming van goederen of bescheiden onder een geheimhouder gepaard behoort te gaan, vereist dat de Deken ook aanwezig is bij de beoordeling door de RC van waar beslag op blijft gehandhaafd en wat er kan worden teruggegeven en dat afwezigheid van de Deken leidt tot nietigheid van de (selectie) beslissing, is in haar algemeenheid onjuist.' Dat moge zo zijn, maar juist vanuit het perspectief van art. 8 EVRM verdient de aanwezigheid van de waarnemer van de beroepsgroep zeker de voorkeur.

I72 HR 4 juni 20I3, LJN BZooo4 (vgl. ook HR 20 februari 2007, LJN AZ3564) en HR 2 juli 20I3, ECLI:NL:HR:20I3:CA0434.

I73 EHRM I6 oktober 2007, nr. 74336/or (Wieser and Bicos Beteiligungen GMBH t. Oostenrijk).

I74 Uitgebreider hierover Handboek Strafzaken, par. I4·3.2.

I75 BVerfG, I BvR 370/07, 27 februari 2008. 
De formulering van de voorwaarden waaronder de bevoegdheid van artikel I25j Sv mag worden toegepast sluit op zichzelf niet uit dat justitie op basis van deze bevoegdheid een onderzoek kan instellen naar in de cloud opgeslagen gegevens, ${ }^{176}$ anders dan de minister van Veiligheid en Justitie tot voor kort leek te veronderstellen. ${ }^{177}$ Gaat het om een zich kennelijk in het buitenland bevindend computersysteem, ${ }^{178}$ dan zal politie of justitie zich, behoudens een uitdrukkelijke verdragsrechtelijke grondslag, echter van onderzoek dienen te onthouden. De Nederlandse wet kan immers, aldus de memorie van toelichting, ${ }^{179}$ geen grondslag bieden voor een onderzoek in een geautomatiseerd werk dat onder de jurisdictie van een ander land valt. ${ }^{180}$ Een en ander zou in de weg kunnen staan aan het vanaf de plaats van doorzoeking onderzoeken van in de cloud geplaatste gegevens, nu deze dikwijls vallen onder de jurisdictie van een ander land. Dit laat uiteraard onverlet dat waar zonder gebruikmaking van publiekrechtelijke bevoegdheden consultatie van bij voorbeeld buitenlandse databanken mogelijk en geoorloofd is, de politie of rechter-commissaris deze middelen niet ongebruikt hoeft te laten. ${ }^{\mathrm{I}{ }^{8 \mathrm{I}}} \mathrm{Heb} \mathrm{ik}$ het goed begrepen dan kent men in België dit probleem niet, daar artikel 88ter Belgisch Wetboek van Strafvordering voorziet in een zelfstandige bevoegdheid om vanaf een computer die zich in dat land bevindt gegevens in de cloud te verzamelen. ${ }^{182}$

$\mathrm{Nu}$ de ontwikkelingen sinds de totstandkoming van de wettelijke bepalingen betreffende de doorzoeking in geautomatiseerde werken hebben geleid tot verschillende, door de wetgever destijds vermoedelijk niet bevroede vormen van opslag van gegevens elders dan op de plaats waar de te doorzoeken computer zich bevindt, lijkt

I76 Aan het in art. I25j Sv vereiste van een 'dubbele band' zal in dat geval veelal zijn voldaan. In een elders aanwezig maar vanaf de plaats van doorzoeking toegankelijk systeem mag justitie geen onderzoek instellen indien de personen die ter plaatse van de doorzoeking aanwezig plegen te zijn of daar wonen, werken of plegen te verblijven zelf tot dat elders aanwezige systeem geen rechtmatige toegang hebben. Dit lijkt ook te impliceren dat de ruime uitleg van 'geautomatiseerd werk' die de Hoge Raad aan dit eveneens in het materiële strafrecht voorkomend begrip (bijvoorbeeld in art. I6rsexies jo. art. 8osexies Sr) heeft gegeven in het Botnet-arrest (HR 22 februari 20II, LJN BN9287, NJ 20I2, 62, m.nt. N. Keijzer) in de context van art. I25j Sv toepassing mist.

I77 Zo bleekt uit het door het ministerie van Veiligheid en Justitie in 2012 bekend gemaakte voornemen om te voorzien in meer opsporingsbevoegdheden ter bestrijding van cybercrime, dat inmiddels heeft geleid tot het wetsvoorstel Computercriminaliteit III, dat de opsporingsbevoegdheden ook op dit punt beoogt uit te breiden. Zie in dit verband ook J.J. Oerlemans, 'Hacken als opsporingsbevoegdheid', DD oktober 20II, 62, p. 888 e.v.

I78 Voor de cloud-gebruiker is het vaak onduidelijk waar de servers zich bevinden en wie daarover zeggenschap toekomt. In Nederland heeft Google een enorme dataopslag in de Eemshaven.

I79 Kamerstukken II I989/90, 2I 55I, nr. 3, p. II, I2 (MvT).

I80 De MvT is niet echt duidelijk over de vraag of het gaat om zich in het buitenland bevindende systemen dan wel om servers waarover een partij in een ander land zeggenschap heeft, ongeacht de plaats waar deze zich bevinden. Zie in dit verband art. 32 Cybercrimeverdrag.

I8I Zo de MvT, p. I2: 'Alsdan is er geen sprake van een onderzoek in de zin van het onderhavige wetsvoorstel. Ik acht het overigens van belang dat een verdragsrechtelijke grondslag, bijvoorbeeld in de vorm van een aanvullend protocol bij het Europees Verdrag aangaande de wederzijdse rechtshulp in strafzaken, tot stand wordt gebracht'. Koops zet vraagtekens bij de opvatting dat door politie en justitie onbeperkt onderzoek in openbare bronnen mag worden verricht (B.J. Koops, 'Politieonderzoek in openbare bronnen op internet', Tijdschrift voor Veiligheid 2012 (II)2, p. 30 e.v.). Zie in dit verband art. 32 Cybercrimeverdrag.

I82 Het is wel de vraag of deze bevoegdheid zich in alle opzichten verdraagt met het Cybercrimeverdrag. 
het verstandig de bevoegdheden tot opsporing daarop af te stemmen. Bijzondere aandacht zal daarbij moeten worden gegeven aan de kwetsbare positie van de verschoningsgerechtigde.

\section{Io Beklag en beslag}

De rechtmatigheid van het beslag en de doorzoeking waarbij het verschoningsrecht in het geding is kan via verschillende wegen ter discussie worden gesteld: ter terechtzitting als beweerd vormverzuim, of daaraan voorafgaand, tijdens via een klaagschrift tegen - kort gezegd - de inbeslagneming (artikel 552a). De beklagprocedure is belangrijk omdat langs deze weg voorkomen kan worden dat gegevens die het verschoningsrecht raken deel gaan uitmaken van het dossier van de hoofdzaak en zo ter kennis kunnen komen van derden. Fundamentele beslissingen over de reikwijdte van het verschoningsrecht worden in de Nederlandse rechtspraktijk daarom dikwijls genomen door de rechtbank in raadkamer, in het kader van de beoordeling van het klaagschrift. De gerechtshoven staan daarbij vrijwel buiten spel omdat tegen de beslissingen van de rechtbank in het kader van de artikel $552 \mathrm{a}$ Sv-procedure geen hoger beroep, maar alleen cassatie openstaat. ${ }^{1{ }^{8}}$

Komen vragen rond het verschoningsrecht voor het eerst aan de orde tijdens de terechtzitting, dan is voor de beantwoording van de vraag welke gevolgen schending van het verschoningsrecht moet hebben artikel 359a Sv leidend. De inbreuk op het verschoningsrecht zal kunnen leiden tot bewijsuitsluiting indien het gebruik voor het bewijs afbreuk zou doen aan, in de woorden van de Hoge Raad, 'het zeer fundamentele belang dat met de bescherming van het verschoningsrecht is gediend ${ }^{1} 84$ (zie hierna, paragraaf 5 ).

De wettelijke regeling van het beklag tegen beslag zoals neergelegd in artikel $552 \mathrm{~S}$ Sv roept vele vragen op. ${ }^{185}$ In het bestek van dit preadvies kunnen niet meer dan enkele daarvan worden belicht. De keus van de thema's is bepaald door de actualiteit van de rechtsontwikkeling in Nederland. Aandacht wordt geschonken aan onderwerpen als: wie kan zich als 'belanghebbende' beklagen over de inbeslagneming, is de verschoningsgerechtigde het aan zijn stand verplicht om in voorkomende gevallen een klaagschrift in te dienen, speelt het nemo tenetur-beginsel een rol in de klaagschriftprocedure, strekt artikel 552a Sv zich uit tot beklag tegen (al dan niet toekomstige) kennisneming en gebruik van gegevens die zijn vastgelegd op of in een inbeslaggenomen voorwerp (op papier, op de harde schijf van een computer

I83 Zeker nu het erop lijkt dat de Hoge Raad (ongeveer) sinds begin 2013 na vernietiging van de op het klaagschrift door de rechtbank gegeven beschikking zelden meer verwijst naar een hof, maar meestal terugwijst naar de rechtbank die de beschikking heeft gegeven. Van Dorst stelt in 2012 nog dat de zaak na vernietiging meestal wordt verwezen naar het hof waaronder de rechtbank ressorteert (A.J.A. van Dorst, Cassatie in strafzaken, 7e druk, Deventer: Kluwer 20I2, p. I55).

I84 HR I9 februari 2013, LJN BY5322 (overzichtsarrest vormverzuimen).

I85 Zovele dat het LOVS Stafbureau een Handreiking procedure beklag tegen beslag ex art. 552a Sv (mei 2013) heeft opgesteld: <www.rechtspraak.nl/Procedures/Landelijke-regelingen/Sectorstrafrecht/Documents/Handreiking-beklag-tegen-beslag-552a-Sv-rechtspraak.nl.pdf $>$. Zie hierover ook R.G.A. Beaujean, 'Beklag tegen inbeslagneming', DD 2013, 39, p. 4Io e.v. 
die wordt in beslag genomen) en: mag de rechter in raadkamer de gesloten enveloppe openen?

\section{Io.I Belanghebbende}

'Belanghebbenden' kunnen zich beklagen over de inbeslagneming, aldus artikel 552a lid I Sv. In de context van het verschoningsrecht is in deze zin uiteraard belanghebbende de verschoningsgerechtigde onder wie de voorwerpen in beslag zijn genomen of wiens gegevens zijn vastgelegd of gevorderd. ${ }^{186}$ Ook wanneer de stukken die onder het verschoningsrecht vallen zich elders bevinden, is de verschoningsgerechtigde als belanghebbende aan te merken. Zo is de verschoningsgerechtigde belanghebbende in een klaagschriftprocedure tegen de inbeslagneming van die voorwerpen of gegevens bij patiënt of cliënt, ${ }^{187}$ evenals bij de inbeslagneming daarvan onder degene die zich kan beroepen op een verschoningsrecht dat is afgeleid van het zijne. Daarnaast is de cliënt zelf belanghebbende ingeval het beslag onder hem heeft plaatsgevonden ${ }^{188}$ en het verschoningsrecht in het geding is. ${ }^{189}$

In HR I2 februari 20I3, LJN BX4284 leek gebroken te worden met deze lijn. In deze zaak stond het klaagschrift centraal dat door de vader die van mishandeling van zijn driejarige dochter werd verdacht, was ingediend tegen de inbeslagneming van het medisch dossier betreffende zijn kind. Dit dossier was namens de arts na een bevel tot uitlevering in een verzegelde enveloppe overgedragen aan de officier van justitie. De Hoge Raad overwoog ambtshalve dat alleen de verschoningsgerechtigde zelf in een beklagprocedure waarin het verschoningsrecht in het geding is, kan worden aangemerkt als belanghebbende in de zin van artikel 552a Sv. Naar oordeel van de Hoge Raad volgt dit uit het feit dat het in beginsel aan de verschoningsgerechtigde is om te bepalen of een inbeslaggenomen voorwerp gegevens bevat die onder zijn verschoningsrecht vallen. Diens standpunt moet worden geëerbiedigd, tenzij er redelijkerwijs geen twijfel over kan bestaan dat dit standpunt onjuist is. De vader had dus niet-ontvankelijk moeten worden verklaard in zijn beklag.

Dat de soep niet zo heet wordt gegeten als deze wordt opgediend blijkt uit HR 4 juni 2013, LJN BZoo4. In deze zaak waren gegevensdragers met onder meer kopieën van e-mailbestanden inbeslaggenomen onder klaagster, de accountant en belastingadviseur van verdachte A. Van het beslag makkte deel uit correspondentie tussen klaagster en de advocaat zie zij had ingeschakeld in verband met advisering omtrent haar rechtspositie ten opzichte van de inmiddels gefailleerde verdachte A. Bij de behandeling in raadkamer van het klaagschrift legde klaagster een brief over van haar advocaat, waarin deze zich beriep op haar verschoningsrecht ten aanzien van de correspondentie met klaagster. De rechtbank had klaagster als

I86 Daaronder is ook het geval dat de verschoningsgerechtigde heeft voldaan aan een bevel tot uitlevering te verstaan.

I87 Bijvoorbeeld HR ig november I985, NJ I986, 533, m.nt. 't $\mathrm{H}$.

I88 Art. II6 Sv stelt teruggave van het inbeslaggenomen voorwerp aan degene onder wie het is inbeslaggenomen voorop. Daarom is de beslagene naar mijn mening steeds, ook wanneer het verschoningsrecht niet in het geding is, belanghebbende in de klaagschriftprocedure.

I89 O.m. HR I2 februari 2002, NJ 2002, 440, m.nt. YB. 
belanghebbende aangemerkt en anders dan in de hiervoor besproken beschikking LJN BX4284 greep de Hoge Raad niet ambtshalve in. Wel gaf de Hoge Raad een extra procedurevoorschrift, dat eerder geen rol speelde in zijn rechtspraak: indien de beklagrechter de overgelegde brief van de verschoningsgerechtigde niet toereikend acht voor de beoordeling van de vraag of bestanden in beslag genomen zijn die object zijn van verschoningsrecht, moet hij de betrokken verschoningsgerechtigde als belanghebbende in de gelegenheid stellen zich dienaangaande uit te laten. Vormt dit een, op het verschoningsrecht toegespitste specialis van de algemene in de rechtspraak geformuleerde regel 'dat op het gerecht de plicht rust om, alvorens op een klaagschrift als bedoeld in artikel $552 \mathrm{a}$ Sv te beslissen, aan de hand van de hem ter beschikking staande gegevens na te gaan of een of meer anderen dan de klager als belanghebbend moet(en) worden aangemerkt'? ${ }^{190}$ En betekent dit dat de beklagrechter in geval van beslag onder en beklag door cliënt of patiënt bij een beroep op het feit dat het inbeslaggenomene valt onder het verschoningsrecht ambtshalve een onderzoek moet instellen naar het oordeel van de verschoningsgerechtigde hierover?

In LJN BX4284, de zaak van het beslag op het medisch dossier van het denkelijk door haar ouders mishandelde meisje, stond centraal het klaagschrift van de vader tegen het beslag dat was gelegd onder de verschoningsgerechtigde. Is de omstandigheid dat het ging om beslag onder de arts beslissend geweest voor de op het eerste gezicht wel erg algemeen geformuleerde regel dat 'alleen de verschoningsgerechtigde in een procedure als de onderhavige waarin het verschoningsrecht in het geding is, kan worden aangemerkt als belanghebbende in de zin van artikel 552a Sv'? Wanneer dat inderdaad een bepalende factor is, zou de cliënt/patiënt alleen als belanghebbende in een klaagschriftprocedure kunnen optreden wanneer het beslag dat het verschoningsrecht raakt onder hem is gelegd. Bij een dergelijke opvatting kunnen tegen de achtergrond van de EHRM-rechtspraak echter wel vraagtekens worden geplaatst. Het EHRM heeft als uitgangspunt geformuleerd dat 'respecting the confidentiality of health data (...) is a vital principle in the legal systems of all the Contracting Parties to the Convention. It is crucial not only to respect the sense of privacy of a patient but also to preserve his or her confidence in the medical profession and in the health services in general. ${ }^{\text {'9r }}$ Beide aspecten, het belang van de privacy van de patiënt en het algemeen belang van vertrouwelijkheid van medische gegevens zijn uiteraard nauw met elkaar verweven. De privacy van de patiënt/cliënt mag dan in onze rechtsorde oorspronkelijk geen rechtstreekse grondslag zijn van het verschoningsrecht, indirect is de bescherming van de privacy onlosmakelijk daarmee verbonden. ${ }^{192}$

I9o Vaste rechtspraak, recent HR I2 juni 20I2, LJN BW7955.

I9I EHRM 25 februari I997, nr. 22009/93, NJ I999, 5I6, m.nt. Kn (Z. t. Finland).

I92 Kritisch hierover A-G Aben in zijn conclusie voorafgaand aan HR 5 juli 20II, LJN BP6I44. In de rechtspraak is echter meerdere keren tot uitdrukking gebracht dat ook het belang van de patiënt - en dus niet alleen het algemeen belang - kan worden geschaad bij een inbreuk op het verschoningsrecht (o.m. HR 2I oktober 2008, LJN BD78I7, NJ 2008, 630, m.nt. J. Legemaate). In de Aanwijzing toepassing opsporingsbevoegdheden en dwangmiddelen tegen advocaten (20IIAoo3) heet het uitdrukkelijk: 'Het verschoningsrecht dient echter niet alleen het belang van het individu'. P. Traest en J. Meese, Het verschoningsrecht naar Belgisch recht (Preadviezen voor de Nederlands-Vlaamse Vereniging voor strafrecht), Nijmegen: Wolf Legal Publishers 2006 stellen 
Wordt onder de arts beslag gelegd op het medisch dossier van een patiënt, dan is vanuit dat perspectief moeilijk te begrijpen dat de patiënt geen belanghebbende bij het beslag is in de zin van artikel 552a Sv. Dat klemt te meer nu de patiënt- en cliëntgegevens tegenwoordig meestal in digitale vorm zijn opgeslagen en het beslag bij doorzoeking ${ }^{\mathrm{I} 33}$ bijna per definitie de gegevens van veel meer patiënten of cliënten omvat dan waarnaar wordt gezocht. Na de inbeslagneming vindt dikwijls pas de tijdrovende filtering plaats (zie paragraaf 9.6). Zijn de vele patiënten die worden getroffen door het beslag dat inbreuk maakt op het verschoningsrecht van hun arts, ${ }^{194}$ dan niet aan te merken als belanghebbenden in de artikel 552a Sv-procedure? ${ }^{195}$ Hun privacy is bij het beslag, gezien tegen de achtergrond van het verschoningsrecht waarmee de privacy onlosmakelijk is verbonden, in hoge mate betrokken. Gelet hierop is het de vraag of het oordeel van de Hoge Raad in LJN BX4284 houdbaar zou zijn geweest wanneer de vader in de artikel 552a Sv-procedure was opgetreden als wettelijk vertegenwoordiger van zijn kind. ${ }^{196} \mathrm{Ik}$ waag dit te betwijfelen. Het lijkt mij de voorkeur te verdienen dat de patiënt of diens wettelijk vertegenwoordiger wordt erkend als belanghebbende in de klaagschriftprocedure waarin het beslag onder de verschoningsgerechtigde centraal staat. In deze procedure moet de verschoningsgerechtigde vervolgens naar zijn oordeel worden gevraagd: vallen de inbeslaggenomen gegevens onder zijn verschoningsrecht, of is er sprake van zeer uitzonderlijke omstandigheden die rechtvaardigen dat het beslag wordt gelegd? Alleen op deze wijze kan recht worden gedaan aan het de nauwe verbondenheid van privacy en verschoningsrecht.

Ook wanneer beslag is gelegd onder de advocaat op stukken/gegevens die onder het verschoningsrecht vallen, zou het naar mijn oordeel aanbeveling verdienen de cliënt als belanghebbende in de zin van artikel 552a Sv aan te merken. Als grond daarvoor geldt niet alleen dat het EHRM het 'legal privilege' niet uitsluitend in de sleutel zet van het algemeen belang ('the legal professional privilege is of great importance for both the lawyer and his client and for the proper administration of justice' $)^{197}$ maar evenzeer en vooral dat dit hof heeft uitgesproken dat het de bescherming van het beroepsgeheim van de advocaat ziet als uitvloeisel van het recht van de cliënt om niet mee te werken aan zijn eigen veroordeling. ${ }^{198}$ Tegen deze achtergrond

dat het belang van het individu 'een eerst mogelijke waarde' is te noemen die door het beroepsgeheim wordt beschermd: 'Het beroepsgeheim verzekert immers aan een individu de toegang tot gewetensvrijheid, gezondheidszorg en verdediging doordat hij weet dat de bij deze gelegenheid toevertrouwde geheimen behoudens in de door de wet toegelaten gevallen niet zullen worden vrijgegeven' (p. II4).

I93 Dit ligt anders bij het beslag na een bevel tot uitlevering.

I94 Een inbreuk op de privacy in abstracto is naar mijn oordeel geen reden om de betrokkene als belanghebbende in de art. 552a Sv-procedure aan te merken, wel deze inbreuk in verbinding met het verschoningsrecht. Schending van het algemeen belang dat ten grondslag ligt aan het verschoningsrecht levert op zichzelf evenmin reden op om de patiënt of cliënt in zijn beklag te ontvangen (zo ook, wat dit laatste betreft, Knigge, conclusie bij LJN BX4282, 5.II).

I95 En is er voor deze betrokkenen een 'effective remedy'?

I96 In LJN BX 4284 was dat niet het geval.

I97 EHRM 6 december 20I2, EHRC 20I3/9I, 9I, m.nt. F.P. Ölçer (Michaud t. Frankrijk).

I98 EHRM 24 juli 2008, NJ 2009, 508, m.nt. T.M. Schalken, par. 4I (Andrée.a. t. Frankrijk). 
is het zeker niet vanzelfsprekend dat de cliënt de toegang tot de beklagrechter wordt ontzegd ingeval het beslag niet onder hem is gelegd.

\section{I0.2 Is de verschoningsgerechtigde verplicht om een klaagschrift in te dienen?}

Het is van algemene bekendheid dat verschoningsgerechtigden bij voorkeur niet vrijwillig, na een daartoe strekkend verzoek, patiënt/cliëntdossiers overhandigen aan justitie. Ook wanneer zij niets te verbergen hebben, vrezen zij civielrechtelijk te worden aangesproken op schending van het beroepsgeheim. Daarom worden de gevraagde stukken vaak pas afgegeven na een bevel tot uitlevering, al dan niet met toepassing van de gesloten enveloppe-procedure. Hoewel de verschoningsgerechtigde niet verplicht is te voldoen aan een dergelijk bevel ${ }^{199}$ geeft de justitiële vordering toch enige juridische rugdekking ten opzichte van patiënt of cliënt. Knigge signaleert een en ander in zijn conclusie bij HR I2 februari 20I3, LJN BX4284, de hiervoor besproken zaak waarin de (van mishandeling verdachte) vader zich op de voet van artikel 552a Sv beklaagde over het beslag dat tot stand kwam na het tot de arts van het kind gerichte bevel tot uitlevering van het medisch dossier:

'Ook [de arts, F. V-S] wenste zich kennelijk in te dekken door middel van een legitimerende verplichting. Daarmee zou, zo lijkt de gedachte te zijn geweest, het ziekenhuis zijn handen in onschuld kunnen wassen. De verantwoordelijkheid wordt als het ware afgeschoven naar de ouders van het kind (die moeten maar klagen) en naar de beklagrechter (die moet de belangen maar afwegen). Het beroepsgeheim en het verschoningsrecht dreigen zo van binnenuit te worden uitgehold. De kern van dat verschoningsrecht is dat de belangenafweging in handen wordt gelegd van de geheimhouder, wiens oordeel moet worden gerespecteerd. Dat werkt alleen als de "verantwoordelijke" zijn verantwoordelijkheid neemt en zich niet verschuilt achter een wettelijke plicht.'

De arts had zich in deze zaak niet beklaagd over het beslag. ${ }^{200}$ Knigge waardeert een en ander duidelijk negatief. In dezelfde conclusie spreekt hij, naar aanleiding van een ander voorbeeld, over de verschoningsgerechtigde 'die niet doet wat van hem verwacht mag worden en geen klaagschrift indient. In dat geval is de eerbiediging van het beroepsrecht onvoldoende gewaarborgd.' Knigge ziet in deze context onder ogen of het onthouden van een beklagrecht aan cliënt of patiënt noodzakelijk is om te voorkomen dat de geheimhouder ervan afziet om zelf bij de beklagrechter op te komen tegen de inbreuk op zijn beroepsgeheim. 'Zolang de geheimhouder zijn rol als bewaker van het beroepsgeheim blijft spelen, is er van een tekort aan rechtsbescherming waarin moet worden voorzien, geen sprake.' Uiteindelijk kiest hij ervoor deze rol van de verschoningsgerechtigde te benadrukken, liever dan het toekennen van een 'zelfstandig' beklagrecht aan cliënt of patiënt.

I99 Art. 96a lid 3 Sv, dat ook van toepassing is verklaard op de vordering van gegevens (bijv. art. I26nd en art. $126 \mathrm{nf} \mathrm{Sv).} \mathrm{Het} \mathrm{bevel} \mathrm{kan} \mathrm{niet} \mathrm{worden} \mathrm{gegeven} \mathrm{aan} \mathrm{de} \mathrm{verdachte} \mathrm{(art.} \mathrm{96a} \mathrm{lid} 2 \mathrm{~Sv}$ ); enkele bijzondere wetten maken hierop een uitzondering.

200 Anders dan bijvoorbeeld in de LUMC-zaak, HR 26 mei 2009, LJN BG5979. Begrijp ik Knigge goed, dan vindt hij dit de koninklijke weg. 
Toch is het de vraag of dat laatste, het erkennen van cliënt of patiënt als 'zelfstandig' belanghebbende in de klaagschriftprocedure, niet leidt tot een aantrekkelijker oplossing, onder meer omdat de visie van de professionele verschoningsgerechtigde op de reikwijdte van het verschoningsrecht in dat geval geen geweld wordt aangedaan. Dat de arts alleen stukken wil overhandigen aan justitie na een bevel tot uitlevering is hem niet euvel te duiden; het civiele aansprakelijkheidsrecht is nu eenmaal ook voor hem een gegeven. Is de arts er daadwerkelijk van overtuigd dat de medische gegevens niet onder zijn verschoningsrecht vallen (dit geval zal zich zelden voordoen) of dat er sprake is van zeer uitzonderlijke omstandigheden (vaak zal het hierom gaan), dan is het begrijpelijk dat hij afziet van het indienen van een klaagschrift tegen de inbeslagneming of het dreigend gebruik van de in beslag genomen gegevens. De belangenafweging vindt dus plaats in deze fase, in deze fase neemt - in de woorden van Knigge - de verantwoordelijke zijn verantwoordelijkheid. Zou, zoals ik in de vorige paragraaf heb bepleit, de cliënt of patiënt als belanghebbende in een klaagschriftprocedure worden erkend ook als het beslag onder de verschoningsgerechtigde heeft plaatsgevonden, en zou de rechter in de beklagprocedure verplicht zijn om de verschoningsgerechtigde te vragen naar zijn visie op het verschoningsrecht in de betrokken zaak - zoals ingeval de cliënt zich beklaagt over een inbreuk op het verschoningsrecht wanneer de stukken bij hem zijn in beslag genomen: HR 4 juni 2013, LJN BZoo04-dan is er van een tekort in rechtsbescherming geen sprake. De positie van de verschoningsgerechtigde wordt gerespecteerd: hij heeft tegen de achtergrond van het civiele aansprakelijkheidsrecht een legitiem belang bij een justitiële vordering tot uitlevering, maar hij behoeft zijn visie geen geweld aan te doen door het indienen van een klaagschrift tegen de inbeslagneming wanneer hij van oordeel is dat zijn rol als geheimhouder en verschoningsgerechtigde daartoe niet noopt. En hoewel de cliënt of patiënt zelden iets zal opschieten met de beslissing op zijn klaagschrift is er geen sprake van een tekort aan rechtsbescherming. Een tekort dat, in Knigge's visie, de verschoningsgerechtigde ertoe zou moeten brengen een klaagschrift in te dienen tegen de inbeslagneming, terwijl deze na afweging van alle belangen daar niets in ziet.

Het erkennen van de cliënt of patiënt als belanghebbende in de artikel 552a Svprocedure legt de verantwoordelijkheid waar deze behoort te liggen. Bovendien doet dit recht aan het eigen belang van cliënt of patiënt bij bescherming door het verschoningsrecht van de professionele verschoningsgerechtigde, zoals dit onder meer in de rechtspraak van het EHRM naar voren komt.

\section{I0.3 Beklag over (toekomstige) kennisneming en gebruik van gegevens}

Artikel $552 \mathrm{a} \mathrm{Sv} v^{20 \mathrm{I}}$ maakte vanouds het indienen van een klaagschrift mogelijk tegen inbeslagneming van voorwerpen en het gebruik daarvan. Na vele wijzigingen ${ }^{202}$ luidt het eerste lid van deze bepaling thans:

201 Evenals de voorloper van deze bepaling, art. I03 Sv.

202 Ik verwijs voor de geschiedenis van totstandkoming van het huidige art. 552a Sv kortheidshalve naar de informatieve en uitgebreide conclusie van A-G Knigge voorafgaand aan HR I7 januari 20I2, LJN BU2O46. 
'De belanghebbenden kunnen zich schriftelijk beklagen over inbeslagneming, over het gebruik van in beslag genomen voorwerpen, over het uitblijuen van een last tot teruggave, over de vordering van gegevens, over de vordering medewerking te verlenen aan het ontsleutelen van gegevens, over de kennisneming of het gebruik van gegevens, vastgelegd tijdens een doorzoeking of op vordering verstrekt, over de kennisneming of het gebruik van gegevens, opgeslagen, verwerkt of overgedragen door middel van een geautomatiseerd werk en vastgelegd bij een onderzoek in zodanig werk, over de kennisneming of het gebruik van gegevens als bedoeld in de artikelen 100, 101 en 114, over de vordering gegevens te bewaren en beschikbaar te houden, alsmede over de ontoegankelijkmaking van gegevens, aangetroffen in een geautomatiseerd werk, bedoeld in artikel 1250, de opheffing van de desbetreffende maatregelen of het uitblijuen van een last tot zodanige opheffing.'

Bij beslag onder een verschoningsgerechtigde draait het in de meeste gevallen om gegevens, ${ }^{203}$ vroeger veelal vastgelegd in dossiers op papier, tegenwoordig meest digitaal beschikbaar. De verschoningsgerechtigde ${ }^{204}$ kan zich beklagen over de kennisneming en het gebruik van deze gegevens, ongeacht of deze zijn neergelegd in papieren dossiers dan wel digitaal zijn vastgelegd op andere gegevensdragers. Naar het oordeel van de Hoge Raad voorziet artikel 552a Sv echter ten aanzien van andere klagers dan verschoningsgerechtigden ${ }^{205}$ niet in het doen van beklag tegen kennisneming en gebruik van gegevens ontleend aan inbeslaggenomen voorwerpen, zoals dagboeken, andere geschriften en voorwerpen als bij een doorzoeking in beslag genomen externe harde schijven. ${ }^{206}$ Evenals de verschoningsgerechtigden kunnen zij wel klagen over de kennisneming of het gebruik van gegevens die bij een doorzoeking zijn vastgelegd of op vordering zijn verstrekt, dan wel vallen onder de categorie van gegevens die zijn opgeslagen, verwerkt of overgedragen door middel van een geautomatiseerd werk en zijn vastgelegd bij een onderzoek in zodanig werk.

Er zijn meer opmerkelijke verschillen tussen de positie van de verschoningsgerechtigde indiener van een klaagschrift en de niet-verschoningsgerechtigde: een gegrond beklag van de verschoningsgerechtigde uitmondend in een last tot teruggave van de inbeslaggenomen bescheiden omvat ook de teruggave (of vernietiging) van alle eventueel gemaakte afschriften, omdat anders immers niet geheimhouding van deze bescheiden wordt bereikt. ${ }^{207}$ Beklag door een niet-verschoningsgerechtigde belanghebbende strekkende tot vernietiging van de kopieën van (de inmiddels teruggeven) bescheiden werd door de Hoge Raad niet-ontvankelijk verklaard omdat de kopieën, anders dan de aanvankelijk in beslag genomen stukken, niet zijn aan te merken als 'inbeslaggenomen voorwerp'. ${ }^{208}$ Een vergelijkbare lijn volgde de Hoge Raad in zijn beschikking van 2 september 2003, LJN AGI758, waarin het

203 Maar ook beslag op bijvoorbeeld bloedmonsters is denkbaar.

204 En zijn cliënt, indien het beslag op stukken die onder het verschoningsrecht vallen bij hem heeft plaatsgevonden.

205 En in voorkomende gevallen: hun cliënt.

206 HR 9 oktober 20I2, LJN BX55I0. De Hoge Raad casseerde de beschikking van de rechtbank, die de klager wel ontvankelijk had geacht in zijn beklag, ambtshalve.

207 HR i6 mei ig89, NJ ig89, 886, m.nt. C.

208 HR 4 oktober I988, NJ I989, 429. Met A-G Knigge in zijn conclusie bij HR I7 januari 20I2, LJN BU2046 meen ik dat het niet aannemelijk is dat anders geoordeeld zou zijn indien de inbeslaggenomen bescheiden nog niet waren teruggegeven ten tijde van de behandeling van het klaagschrift. 
klaagschrift strekte tot teruggave van foto's gemaakt met een in beslag genomen wegwerpcamera. De Hoge Raad oordeelde dat de rechtbank klaagster niet-ontvankelijk had moeten verklaren in haar beklag nu weliswaar onder de klaagster een wegwerpfototoestel met daarin een fotorolletje in beslag is genomen, doch niet dat beslag is gelegd op enige foto die met behulp van bedoeld toestel is gemaakt. ${ }^{209}$

Een derde verschil tussen de positie van de verschoningsgerechtigde klager en de niet-verschoningsgerechtigde is dat in de rechtspraak aanvaard is dat de eerste zich kan beklagen over de voorgenomen kennisneming ${ }^{210}$ van digitale of 'papieren' gegevens. Een dergelijk preventief ${ }^{211}$ beklag is buiten de sfeer van het verschoningsrecht geen gemeen goed, hoewel de rechtspraak van de Hoge Raad daarvoor wel steeds meer ruimte lijkt te bieden. ${ }^{212}$

Knigge $^{213}$ verklaart de hiervoor aangeduide afwijkende lijn die de Hoge Raad volgt bij beklagzaken betreffende het verschoningsrecht vanuit de wens een tekort in de rechtsbescherming rond het verschoningsrecht op te heffen. Hoewel het lastig is in de ziel van de Hoge Raad te kijken lijkt mij dit een aannemelijke verklaring. Maar het is de vraag of deze omweg via het tekort in rechtsbescherming rond het verschoningsrecht nodig en juist is.

Ter beantwoording van deze vraag moet worden teruggegaan naar de invoering van artikel I25i Sv in 2006. Deze bepaling behelst de bevoegdheid tot het doorzoeken van een plaats 'ter vastlegging van gegevens'. Vóór 2006 was het ook al mogelijk om een plaats te doorzoeken ter vastlegging van gegevens; deze bevoegdheid werd geacht opgesloten te liggen in de gewone doorzoekingsbevoegdheid van de artikelen 96b, 97 en Iı Sv. Reden van invoering was dat duidelijk gemaakt moest worden dat een doorzoeking kon worden verricht uitsluitend ter vastlegging van gegevens. ${ }^{214}$ Over de mogelijkheid daartoe bestond in de praktijk namelijk onduidelijkheid. ${ }^{215}$ De normering van de bevoegdheid van artikel $125 \mathrm{i} \mathrm{Sv}$ is doelbewust door de wetgever niet afhankelijk gesteld van de wijze waarop de gegevens zijn vastgelegd. ${ }^{216}$ De bepaling heeft dus betrekking op gegevens die zich op de harde schijf of in het

209 Volgens Knigge in zijn in de vorige noot genoemde conclusie kan wel worden geklaagd over het gebruik van foto's af komstig uit een inbeslaggenomen digitale camera. Dat betwijfel ik. Print de politie na inbeslagneming van de camera de foto's dan is er geen sprake van 'kennisneming of het gebruik van gegevens, opgeslagen, verwerkt of overgedragen door middel van een geautomatiseerd werk en vastgelegd bij een onderzoek in zodanig werk'.

2IO De gesloten enveloppe-procedure.

2II Preventief in de zin dat er van het inbeslaggenomene nog geen kennis is genomen; de inbeslagneming heeft echter wel plaatsgevonden.

2 I2 Zie het overzicht in de conclusie van A-G Vellinga bij HR I7 oktober 2006, LJN AYor93 (snelheidsgegevens blackbox).

213 Conclusie bij HR I2 februari 2013, LJN BX4284.

2I4 Daaraan zien C. Conings en J.J. Oerlemans m.i. voorbij in 'Van een netwerkzoeking naar online doorzoeking: grenzeloos of grensverleggend?', Computerrecht 2013, 5 (online geraadpleegd).

215 Inbeslagneming van de gegevensdrager is immers dikwijls onpraktisch en disproportioneel. Zie hierover F. Vellinga-Schootstra, Handboek Strafzaken, par. I4.I3.I (januari 20I3) en E.C. Mac Gillavry, Met wil en dank (Een rechtsvergelijkend onderzoek naar de medewerking aan strafvordering door bedrijuen), Nijmegen: Wolf Legal Publishers 2004, p. 70-7I.

2I6 Rapport van de Commissie Strafvorderlijke gegevensvergaring in de informatiemaatschappij (commissie-Mevis), mei $200 \mathrm{I}$ (<www.justitie.nl/rapporten>), p. 46 en Kamerstukken II 2003/04, 29 44I, nr. 3, p. II (MvT). 
werkgeheugen van de computer bevinden, op gegevens op een usb-stick, maar ook op gegevens op papier. ${ }^{217}$ Gegevens kunnen worden vastgelegd ten behoeve van de waarheidsvinding, of met het oog op andere strafvorderlijke doeleinden. ${ }^{218}$ Buiten kijf staat dat bij de 'gewone' doorzoeking van artikel 96b e.v. Sv ook naar (al dan niet digitale) gegeven $\mathrm{s}^{219}$ mag worden gezocht en dat deze in het kader van dat onderzoek ook kunnen worden vastgelegd. Voor de wetgever was juist de techniek-onafhankelijkheid van artikel I25i Sv van belang. Er was geen reden om te onderscheiden naar de aard van de gegevens.

Merkwaardig genoeg is de wijze waarop de gegevens technisch gesproken zijn vastgelegd in de rechtspraak van de Hoge Raad wel bepalend voor de uitleg van de reikwijdte van artikel 552a Sv. Zoals we immers hebben gezien acht de Hoge Raad voor de vraag of kan worden geklaagd over het gebruik van gegevens doorslaggevend of er sprake is van inbeslagneming van een voorwerp, dan wel - kort gezegd - vastlegging van gegevens. ${ }^{220}$ De onduidelijke formulering van artikel $552 \mathrm{a}$ Sv geeft daartoe enige redenen. Maar de misverstanden die bij wetgever en rechter gemakkelijk ontstaan zodra de techniek zijn intrede doet, zouden voor de uitleg van artikel 552a Sv niet bepalend moeten zijn. Bij het beslag ten behoeve van de waarheidsvinding op gegevens die op papier zijn vastgelegd (de administratie, het dagboek van Ina Post, ${ }^{221}$ het dagboek van de minderjarige, verstandelijk gehandicapte jongen, verdacht van het jegens een zesjarig meisje gepleegde zedendelict, ${ }^{222}$ zijnde voorwerpen in de zin van o.m. artikel 552a Sv), richt het bezwaar tegen het beslag zich immers uiteraard, anders dan aan de rechtspraak van de Hoge Raad ten grondslag lijkt te liggen, veelal niet tegen de inbeslagneming van het papier, van het dagboekje, maar tegen de kennisneming ${ }^{223}$ of het gebruik van de gegevens die dat

2 I7 Klassieke 'papieren gegevens' kunnen bijvoorbeeld worden gekopieerd; de vroegere kopieerbepaling, art. Iog Sv, is bij invoering van het huidige art. I25i Sv vervallen.

218 Art. I25i Sv spreekt over het vastleggen van gegevens 'in het belang van het onderzoek'. Genoemd belang is naar mijn oordeel niet beperkt tot de waarheidsvinding, zeker niet nu in 2006 afstand is genomen van de bewoordingen van de voorloper van de huidige bepaling, waarin gesproken werd over het belang van de waarheidsvinding. Anders: MvT Computercriminaliteit III, p. 76.

2I9 Onbegrijpelijk is dat op p. 76 van de MvT op het onlangs ingediende wetsvoorstel Computercriminaliteit III gesteld wordt dat de term 'doorzoeking' verband houdt met het onderzoek van een fysieke plaats en dat daarom wordt gekozen voor de term 'onderzoek in een geautomatiseerd werk'. Kern van de wijziging van de term 'huiszoeking' in 'doorzoeking' was immers dat niet langer de plaats van onderzoek ('huis') bepalend was voor de kwalificatie als 'doorzoeking', maar de intensiteit van het onderzoek. Een doorzoeking kan overal worden verricht (ook in een geautomatiseerde omgeving). Zie hierover F. Vellinga-Schootstra, 'Van huiszoeking naar doorzoeking, een stille revolutie', NJB 2000, p. 928 e.v.

220 In het materiële strafrecht laat de Hoge Raad zich bij de interpretatie van delicten die zich daarvoor lenen geen rad voor de ogen draaien door de techniek: HR 29 januari 2013, LJN BY9oo5 (filmbeelden kunnen worden begrepen onder voorwerpen). Opvallend genoeg wel bij de uitleg van art. 552a Sv, waarin juist de rechtsbescherming (en niet de reikwijdte van de delictsomschrijving) voorop staat.

22I Genoemd in de vele procedures in deze zaak, o.m. in HR 23 juni 2009, LJN BIr689.

222 HR 24 januari 2006, LJN AU4666.

223 De bevoegdheid tot inbeslagneming omvat volgens vaste rechtspraak die tot het onderzoeken van het voorwerp; recent bijvoorbeeld ten aanzien van inbeslaggenomen voorwerpen in het algemeen en ten aanzien van computers in het bijzonder HR 4 juni 20I3, LJN BZoo4. 
papier, dat dagboekje bevat. ${ }^{224}$ Zo gezien beschermt artikel 552a Sv niet uitsluitend het bezit of de eigendom van het papier of het voorwerp, en gaat het bij beslag zeker niet alleen om voorwerpen met waarde in het economische verkeer. ${ }^{225}$ Sterker, voor de waarheidsvinding is die economische waarde in de regel volstrekt niet relevant. Wordt dit onder ogen gezien, dan heeft de Hoge Raad in de rechtspraak over het beklag over het verschoningsrecht geen oneigenlijke toepassing gegeven aan artikel $552 \mathrm{a}$ Sv: ongeacht welke bevoegdheid ten grondslag ligt aan het beslag op gegevens (inbeslagneming van papieren dossier of computer, het vorderen van gegevens, het bevelen van uitlevering) kan in het kader van de beklagprocedure geklaagd worden over de kennisneming/het gebruik van de gegevens. De onduidelijke formulering van artikel 552a Sv en de misverstanden rond de werkelijkheid in de papieren en de digitale wereld die daaraan ten grondslag liggen, zouden geen barrière moeten vormen voor de rechtsbescherming rond het beslag. ${ }^{226}$ Het klaagschrift dat zich richt tegen het uitblijven van een last tot teruggave van de foto's die gemaakt zijn met een inbeslaggenomen en inmiddels teruggegeven camera (de foto's zijn kennelijk door de politie afgedrukt) ${ }^{227}$ kan in deze opvatting niet niet-ontvankelijk worden verklaard om reden dat wel beslag rustte op het fototoestel maar niet op de daarmee gemaakte foto's. ${ }^{228}$

Zo zijn er ook goede gronden om vastlegging van gegevens (artikel I25i Sv) te begrijpen als het equivalent van 'inbeslagneming' van voorwerpen. De term 'inbeslagneming' van gegevens wilde de wetgever niet bezigen omdat het onder zich nemen door justitie van papieren gegevens zoveel zou verschillen van het in beslag nemen van digitale gegevens. ${ }^{229}$ De doorzoeking ter vastlegging van gegevens is dus de evenknie van de doorzoeking ter inbeslagneming van voorwerpen. ${ }^{230}$ In artikel $552 \mathrm{a} \mathrm{Sv}$ is deze terminologie niet uit de verf gekomen, met als resultaat de invoering van het gesignaleerde merkwaardig en juist wel techniek-afhankelijk onderscheid tussen de reikwijdte van het beklag tegen inbeslagneming van voorwerpen

224 Dat de wetgever dit aanvankelijk ook zo zag, zou kunnen worden afgeleid uit de bewoordingen van art. 552a Sv, waar gesproken wordt over kennisneming en gebruik van gegevens als bedoeld in de art. IOo, IOI en II4 Sv, die handelen over het beslag op poststukken. Uiteraard gaat het bij het beslag op poststukken mede om de gegevens die de brieven e.d. behelzen.

225 Anders conclusie A-G Knigge bij LJN BU2046, I3.I. Vergelijk de discussie rond de vraag of een 'goed' in de zin van art. 310 Sr vermogenswaarde moet hebben; zie F. Vellinga-Schootstra, Gegevensbescherming en strafrecht (Preadvies Nederlandse Juristen-Vereniging I988), Zwolle: W.E.J. Tjeenk Willink I988, p. I47-I49. Ten aanzien van art. 317 Sr: HR 28 mei 2013, LJN BX7959.

226 Anders Knigge, conclusie bij HR 9 oktober 2012, LJN BX5510: 'Ik merk daarbij op dat voor een extensieve interpretatie van art. 552a Sv niet direct reden lijkt te zijn, nu de beklagregeling op dit punt niet goed lijkt te zijn doordacht.'

227 Zo Knigge in zijn conclusie bij LJN BU2046.

228 HR 2 september 2003, LJN AGI758.

229 Vgl. in dit verband Gegevensbescherming en strafrecht (Preadvies NJV I988), p. I8I, I82. Strikt genomen biedt art. 552a Sv geen mogelijkheid van beklag tegen de vastlegging zelf, zoals wel tegen de inbeslagneming.

230 Anders B.J. Koops, die - als ik hem goed begrijp - het ontoegankelijk maken van gegevens (art. I250 Sv) ziet als bevoegdheid die naar de kern genomen vergelijkbaar is met de inbeslagneming van voorwerpen ('Computerrecht. Virtuele en reële delicten. Een beschouwing over het RuneScape-arrest en computercriminaliteitswetgeving', Computerrecht 2013, 4 (online geraadpleegd). Zijn standpunt laat opnieuw zien hoe dringend concepten als goed, wegnemen, gegeven en inbeslagneming aan heroverweging toe zijn. 
(dossiers, usb-sticks, harde schijven) enerzijds en gegevens die zijn vastgelegd bij een onderzoek in een geautomatiseerd werk anderzijds. Zoals de verschoningsgerechtigde zich kan beklagen over de kennisneming van gegevens vastgelegd op papier - te rubriceren onder 'gebruik' van de inbeslaggenomen voorwerpen ${ }^{231}-$ zo zou naar mijn oordeel buiten de context van het verschoningsrecht moeten kunnen worden geklaagd over het gebruik van inbeslaggenomen bescheiden, bijvoorbeeld over de kennisneming van het dagboek dat in het belang van de waarheidsvinding door justitie onder zich genomen is.

De mogelijkheid tot het indienen van een klaagschrift gericht tegen de toekomstige kennisneming van de gegevens die onder gesloten couvert aan justitie zijn afgestaan - de gesloten enveloppe-procedure: 'preventief' beklag, bekend uit zaken waarin beslag onder verschoningsgerechtigden centraal staat - is al enige tijd niet meer voorbehouden aan de verschoningsgerechtigde, zoals HR I2 december 20I0, LJN BLo666 - een economische strafzaak - en HR I7 oktober 2006, LJN AYor93 ${ }^{232}$ - een onderzoek in verband met artikel 5 WVW 1994 - laten zien. Dat is een begin. Nu nog de volgende stap, het ook buiten de context van het verschoningsrecht erkennen van de mogelijkheid een klaagschrift in te dienen tegen de kennisneming van gegevens die, kort gezegd, aan 'voorwerpen' zijn ontleend en die naar de letter genomen niet vallen onder de categorie die artikel 552a lid I Sv noemt.

\section{I0.4 De maatstaf voor toetsing van het beslag in verschoningsrechtkwesties}

In het kader van de artikel552a Sv-procedure kan de verschoningsgerechtigde belanghebbende zich beklagen over onder meer de rechtmatigheid van het beslag en het uitblijven van een last tot teruggave, alsmede over het gebruik van in beslag genomen voorwerpen, de kennisneming en het gebruik van vastgelegde gegevens in de zin van het eerste lid van artikel $552 \mathrm{a}$ Sv en over de vordering van gegevens. In verschoningsrechtzaken spitst het beklag zich dikwijls toe op de vraag of er sprake is van 'zeer uitzonderlijke omstandigheden' op basis waarvan het verschoningsrecht kan worden doorbroken. Aan de inbeslagneming is in de meeste gevallen een gesloten enveloppe-procedure voorafgegaan, ingezet hetzij tijdens de doorzoeking ter inbeslagneming (artikel $98 \mathrm{~Sv}$ ), hetzij na een bevel tot uitlevering van gegevens (bijvoorbeeld artikel I26nf Sv) of voorwerpen (artikel 96a, I05 Sv).

De toetsing of zeer uitzonderlijke omstandigheden aanwezig zijn die meebrengen dat een inbreuk op het verschoningsrecht geoorloofd is, maakt deel uit van de rechtmatigheidstoetsing. ${ }^{233}$ De rechtmatigheidstoetsing omvat naar algemeen wordt aangenomen de toetsing aan de voorwaarden die de wet en jurisprudentie aan het beslag verbinden (bevoegde personen, vatbare voorwerpen, overige voorwaarden,

23I Zo begrijp ik HR I9 november I985, NJ I986, 533, m.nt. 't $\mathrm{H}$, in het bijzonder overweging 5.5.2.

232 Het ging om de snelheidsgegevens opgeslagen in de blackbox; de blackbox was in beslag genomen na een bevel tot uitlevering op grond van art. I25i oud Sv. Zie hierover ook Knigge, conclusie bij HR I7 januari 20I2, LJN BU2046, I3.15.

233 Er is hier geen sprake van een marginale toetsing, maar van een 'volle' rechtmatigheidstoets: HR I5 mei 2007, LJN BAo49I, NJ 2007, 300. 
zoals heterdaad, dringende noodzakelijkheid; daarnaast de aan doorbreking van het verschoningsrecht verbonden jurisprudentiële voorwaarde dat er sprake is van zeer uitzonderlijke omstandigheden enzovoort), alsmede toetsing aan de beginselen van proportionaliteit en subsidiariteit. ${ }^{234}$

In dit licht opvallend is HR I2 februari 20I3, LJN BV3004. In deze zaak stond het klaagschrift centraal dat de medisch directeur van een privékliniek, verdacht van onder andere zware mishandeling van patiënten, had ingediend tegen het beslag, dat was tot stand gekomen na een bevel tot uitlevering aan de Inspectie voor de gezondheidszorg (IGZ) van het IGZ-dossier. Dat dossier bevatte onder meer patiëntdossiers. Een van de cassatiemiddelen richtte zich tegen het oordeel van de rechtbank dat de inbeslagneming van de stukken waarin de door de arts aan de IGZ verstrekte gegevens waren vastgelegd, niet in strijd was met het nemo tenetur-beginsel. Op basis van het summiere karakter van de procedure van artikel 552a Sv oordeelde de Hoge Raad onder meer dat het onderzoek in raadkamer zich kan uitstrekken tot vragen met betrekking tot de rechtmatigheid van het beslag, maar niet tot de nemo tenetur-kwestie:

5.2. Vooropgesteld moet worden dat het onderzoek in raadkamer naar aanleiding van een klaagschrift als bedoeld in artikel $552 a$ Sv een summier karakter draagt. Dat betekent dat van de rechter niet kan worden gevergd ten gronde in de mogelijke uitkomst van een nog te voeren hoofdzaak of ontnemingsprocedure te treden. Daarvoor is in de beklagprocedure geen plaats omdat ten tijde van een dergelijke procedure veelal het dossier zoals dat uiteindelijk aan de zittingsrechter in de hoofdof ontnemingszaak zal worden voorgelegd, nog niet compleet is en omdat voorkomen moet worden dat de beklagrechter vooruitloopt op het in de hoofd- of de ontnemingszaak te geven oordeel (vgl. HR 28 september 2010, LJN BL2823, NJ 2010/654).

5.3. Hieruit volgt dat het onderzoek in raadkamer zich wel kan uitstrekken tot vragen met betrekking tot de rechtmatigheid van het beslag zelf, waarmee wordt gedoeld op de formaliteiten waaraan een inbeslagneming moet voldoen, doch niet tot vragen die betrekking hebben op de mogelijke onrechtmatigheid van gebruik voor het bewijs van hetgeen door de inbeslagneming is verkregen.'

Opvallend is allereerst dat de Hoge Raad het begrip 'rechtmatigheid' in deze context nader definieert: daarmee wordt gedoeld op de formaliteiten waaraan een inbeslagneming moet voldoen. Dit roept de vraag op of hiermee bedoeld is het begrip 'rechtmatigheid' te versmallen tot de wetmatigheid van het beslag: de voorwaarden die

234 De rechtsbeginselen proportionaliteit en subsidiariteit zijn soms terug te vinden bij de wettelijke voorwaarden van het beslag en de daartoe ingezette dwangmiddelen, zoals bijvoorbeeld in art. 3 lid 3 Algemene wet op het binnentreden ('indien (...) redelijkerwijs vereist') en in art. 97 Sv (dringende noodzakelijkheid). Corstens/Borgers noemt bij de rechtmatigheidstoetsing de vraag of het belang van het hervatten van verdachtes bedrijfsactiviteiten, die in het gedrang zijn gekomen door het beslag, al dan niet zwaarder weegt dan het belang der waarheidsvinding (Het Nederlands strafprocesrecht, 7e druk, p. 500). Zie voor het begrip rechtmatigheidstoetsing ook Y.G.M. Baaijens-van Geloven en J.B.H.M. Simmelink, 'Normering van de opsporing', in: M.S. Groenhuijsen en G. Knigge (red.), Dwangmiddelen en rechtsmiddelen, derde interimrapport onderzoeksproject Strafuordering 2001, Deventer: Kluwer 2002, p. 562 e.v. Zie ook R.M. Vennix, Boef en beslag. De strafvorderlijke inbeslagneming van voorwerpen (diss. Nijmegen), Nijmegen: Ars Aequi Libri 1998, p. 277-278, die zelfs enige ruimte ziet voor het betrekken van de doelmatigheid van het beslag ('opportuniteitsoverwegingen') in de toets door de beklagrechter. 
de wet aan de beslaglegging verbindt. Zo wordt het begrip 'formaliteiten' meestal begrepen. ${ }^{235}$ Het is nauwelijks voor te stellen dat de Hoge Raad met de keuze van deze terminologie beoogt de klok zo ver terug te zetten. Dit zou een wezenlijke beperking van de rechtsbescherming betekenen..$^{236}$ Het is daarom de vraag of de overweging van de Hoge Raad wel in deze zin moet worden geduid. Toch doet een recent oordeel van de hoogste rechter ${ }^{237}$ het ergste vrezen.

Daarnaast is opvallend dat de Hoge Raad op het eerste gezicht van oordeel lijkt te zijn dat het summiere karakter van de raadkamerprocedure tot gevolg heeft dat kwesties rond het nemo tenetur-beginsel niet met de rechtmatigheid van de inbeslagneming zoals deze aan de orde is in de context van artikel 552a Sv, van doen hebben:

'5.4. De vragen met betrekking tot het nemo tenetur-beginsel houden verband met de vraag of de verdachte gehouden was de verzochte gegevens aan de IGZ te verstrekken en daarmee met de vraag of die gegevens tot bewijs kunnen strekken. Met de al dan niet rechtmatigheid van de inbeslagneming zelve, als onder 5.3 hiervoor bedoeld, hebben die vragen niet van doen.'

Daarmee lijkt gebroken te worden met rechtspraak uit het verleden, aldus Noorduyn en Kelder. ${ }^{23^{8}}$ Het is spijtig dat de Hoge Raad het oordeel in de IGZ-beschikking zo schraal heeft gemotiveerd. Als het inderdaad de strekking heeft nemo tenetur-vragen in de artikel 552a Sv-procedure buiten de deur te houden komt de vraag op of het oordeel misschien te maken heeft met het één week na deze zaak gewezen nieuwe overzichtsarrest betreffende de rol van de bewijsuitsluiting in de

235 Aldus versta ik ook het begrip 'beslagformaliteiten' in M.J. Borgers, 'Beslagformaliteiten', DD 2008, p. Io6I-I092.

236 Deze zou bovendien ook willekeurig kunnen uitwerken, omdat in jonge wetten facetten van proportionaliteit en subsidiariteit vaker uitdrukking hebben gevonden dan in oudere wetten. Zo wordt bijvoorbeeld in eigentijdse wetgeving de uitoefening van de bevoegdheid meer dan vroeger gebonden aan het vereiste dat uitoefening van de bevoegdheid 'redelijkerwijs vereist moet zijn'. Maakt deze voorwaarde daarmee deel uit van de 'beslagformaliteiten', en behoort deze in gevallen waarin de wet een dergelijke voorwaarde niet bezigt tot de rechtsbeginselen, waaraan de beklagrechter niet zou mogen toetsen?

237 HR 2 juli 2013, ECLI:NL:HR:3013, I30. Als voorbeeld van 'formaliteiten' van het beslag noemt de Hoge Raad art. 94b Sv. In de beschikking wordt overigens gesproken van een redelijk vermoeden van schuld aan enig strafbaar feit ten aanzien van klager wiens auto werd doorzocht. Dat lijkt mij voor de doorzoeking echter juist niet vereist. Moeilijk te doorgronden vind ik ook de overweging 'In het kader van een beklagprocedure dient de vraag of jegens de klager een redelijk vermoeden van schuld aan enig strafbaar feit bestond op het moment van zijn aanhouding en de doorzoeking van zijn auto, beoordeeld te worden met het oog op beantwoording van de vraag of een belang van strafvordering aanwezig is voor het voortduren van het beslag.' [curs. F. V-S]. Voor het voortduren van het beslag ter voorbereiding van de verbeurdverklaring zal dat in de regel gelden, voor beslag ter veiligstelling van de mogelijkheid van onttrekking aan het verkeer of beslag in verband met de waarheidsvinding lijkt dat minder dwingend te zijn.

238 C.W. Noorduyn en Th.J. Kelder, 'Klagen over nemo tenetur? Niet langer bij de beklagrechter!', NJB 2013, 608, p. 751-752; zij stellen dat wanneer alleen bij de behandeling van de hoofdzaak kan worden geklaagd over schending van het nemo tenetur-beginsel het kwaad al is geschied: de stukken bevinden zich dan in het strafdossier en de procespartijen en de rechter hebben er kennis van kunnen nemen. 
artikel 359a Sv-problematiek. ${ }^{239}$ Werpt de daarin besproken en aan banden gelegde bewijsuitsluiting misschien zijn schaduw terug op de artikel 552a Sv-procedure? Er is ook een andere lezing van de beschikking mogelijk. De arts, klager in de procedure, had medische gegevens van patiënten overhandigd aan toezichthouder IGZ, die op de voet van artikel 5:20 Algemene wet bestuursrecht (Awb) van de arts medewerking daartoe kon vorderen. ${ }^{24}$ De cassatiemiddelen in deze zaak bevatten verschillende klachten. Het tweede middel was toegespitst op de vraag of de inbeslagneming en het gebruik van het IGZ dossier - dat na een tot het IGZ gericht bevel tot uitlevering in handen was gekomen van justitie - rechtmatig was. Dat middel slaagde goeddeels omdat het oordeel of de medische informatie onder het verschoningsrecht valt van de arts niet toekomt, zoals de rechtbank had geoordeeld, aan de IGZ maar in beginsel aan de arts zelf.

Het derde middel stelde de nemo tenetur-kwestie in relatie tussen de klager en het IGZ aan de orde. De vraag of verdachte op grond van artikel 5:20 Awb verplicht was de gegevens te verstrekken aan de IGZ valt niet onder het bereik van artikel 552a Sv. Het is immers de toezichthouder en niet politie of justitie die de medewerking van de arts heeft gevorderd. ${ }^{241}$ Van een strafvorderlijk beslag is in deze fase daarom geen sprake. In de hoofdzaak kan de nemo tenetur-vraag zeker wel een rol spelen, waar het gaat om de bruikbaarheid voor het bewijs van in de toezichtfase verplicht verstrekte, aan het strafdossier toegevoegde gegevens: kunnen deze zonder schending van artikel 6 EVRM voor het bewijs worden gebezigd?242

Zo gelezen betekent het oordeel van de Hoge Raad niet dat nemo tenetur-kwesties nimmer in de artikel 552a Sv-procedure aan de orde kunnen komen, hoewel de niet glasheldere overweging 5.3 dat misschien wel suggereert. Op deze wijze uitgelegd is er ook geen sprake van strijd met eerdere rechtspraak als bijvoorbeeld HR 2I december 20I0, LJN BLo666, ${ }^{243}$ waarin het in cassatie ging om de vraag of de klaagster moest voldoen aan het bevel tot uitlevering aan justitie van documenten die zij als bedrijf verplicht was te vervaardigen naar aanleiding van een incident in het bedrijf.

239 HR I9 februari 20I3, LJN BY532I. Zie over dit arrest ook Y. Buruma, 'Vooraf', NJB 20I3, 494, p. 595 e.v., R. de Winter, 'Heeft de Hoge Raad emoties? Over bewijsuitsluiting en onrechtmatig verkregen bewijs', NJB 2013, I253, p. I33I e.v. en T. Schalken, 'Een renaissance van vormverzuimen in het strafrecht?', NJB 2013, I30I, p. I39I e.v. Over de reactie op vormverzuimen in het strafrecht in het algemeen o.m. M. Borgers en T. Kooijmans, 'Alternatieven voor rechterlijke controle op vormverzuimen', in: M.S. Groenhuijsen, T. Kooijmans en J.W. Ouwerkerk, Roosachtig strafrecht: Liber amicorum Theo de Roos, Deventer: Kluwer 2013, p. I7 e.v., G.J.M. Corstens en R. Kuiper, 'Nietontvankelijkverklaring van het openbaar ministerie als reactie op een vormverzuim', in: Roosachtig strafrecht, p. I25 e.v.

240 Op basis van het tweede lid van deze bepaling kan de geheimhouder onder omstandigheden medewerking weigeren. De Wet uitbreiding van de bestuurlijke handhavingsinstrumenten in de wetgeving op het gebied van de volksgezondheid was nog niet van toepassing op deze zaak.

24I Terzijde: het bevel tot uitlevering op de voet van art. I05 dan wel I26nf Sv kan, anders dan door de klager was aangevoerd, wel aan de verschoningsgerechtigde worden gegeven, maar deze is niet verplicht daaraan gevolg te geven wanneer zijn plicht tot geheimhouding daaraan in de weg zou staan.

242 Hier wordt volstaan met een verwijzing naar de in de conclusie bij deze zaak genoemde EHRMrechtspraak. Als indicatie voor de juistheid van deze uitleg van het arrest van de Hoge Raad kan mogelijk gelden dat de Hoge Raad art. 5:20 Awb niet noemt bij de toepasselijke wettelijke voorschriften.

243 NJ 20II, 425, m.nt. J.M. Reijntjes. 
Deze vraag heeft wel betrekking op de rechtmatigheid van de inbeslagneming in het belang van de strafvordering en kon daarom in de artikel 552a Sv-procedure een rol spelen.

\section{I0.5 De beklagrechter en de gesloten enveloppe}

Wanneer de inbeslaggenomen stukken of voorwerpen (te denken is aan een dvd met gegevens, een externe harde schijf) in gesloten enveloppe of doos op het kabinet van de rechter-commissaris zijn bewaard en de verschoningsgerechtigde ${ }^{244}$ zich over de inbeslagneming beklaagt, rijst de vraag of de rechtbank in het kader van de raadkamerprocedure de enveloppe of doos mag openen om kennis te nemen van de inbeslaggenomen gegevens. In de praktijk komt niet alleen voor dat de beslagleggende rechter-commissaris, evenals zelfs de vertegenwoordiger van de beroepsgroep, geen kennis neemt van de inhoud van de stukken, maar ook dat de rechter in de klaagschriftprocedure de enveloppe of doos gesloten laat en als het ware geblinddoekt een beslissing neemt over het klaagschrift. ${ }^{245}$

Dat lijkt merkwaardig, nu de tussenkomst van de rechter juist is ingeroepen om, bijvoorbeeld, te beoordelen of gelet op de aard en de inhoud van het materiaal waarover het verschoningsrecht zich uitstrekt en de mate waarin de belangen van cliënten of patiënten worden geschaad, sprake is van zeer uitzonderlijke omstandigheden. ${ }^{246}$ Bovendien moet de rechter zich in de artikel 552a Sv-procedure een oordeel kunnen vormen over de vraag of het beslag de waarheidsvinding dient. Vaak zal een dergelijk oordeel niet kunnen worden gevormd zonder kennisneming van de stukken waarop het beslag rust. En hoe moet de rechter geblinddoekt beslissen of de inbeslaggenomen stukken al dan niet zijn aan te merken als corpora of instrumenta van het strafbare feit, in welk geval deze niet onder het verschoningsrecht vallen? Uiteraard zal de kennisneming zo beperkt mogelijk moeten plaatsvinden, en zal deze zelfs achterwege moeten blijven wanneer zonder inzage van de stukken te beoordelen is of het klaagschrift al dan niet gegrond is. Maar wanneer kennisneming nodig is om tot een verantwoorde toetsing te komen zal de rechter daarvan niet mogen afzien. Dat de rechter daarmee een kennisvoorsprong krijgt op het Openbaar Ministerie ${ }^{247}$ is een ongelijkheid die wordt gerechtvaardigd door zijn taak en positie in de klaagschriftprocedure. ${ }^{248}$

Aanknopingspunt voor het standpunt dat de beklagrechter in verschoningsrechtzaken indien nodig kennis moet nemen van de inhoud van de gesloten enveloppe is te vinden in een beklagzaak waarin niet het verschoningsrecht, maar het nemo tenetur-beginsel centraal stond. De Hoge Raad oordeelde dat het antwoord op de vraag of het nemo tenetur-beginsel door het beslag was geschonden afhankelijk

244 Andere belanghebbenden in de zin van art. 552a Sv laat ik hier buiten beschouwing.

245 Zie bijvoorbeeld de feitelijke gang van zaken in HR I7 oktober 2006, LJN AW 3558 en in HR 30 oktober 2007, LJN BA5666 en BA56II.

246 In deze zin ook Machielse in zijn conclusie voorafgaand aan HR ro november 2009, LJN BJ7259, NJ 2010, 599, m.nt. Y. Buruma.

247 En in sommige gevallen misschien ook op cliënt/patiënt.

248 Vergelijk EHRM 8 januari 2013, nr. 40238/02, EHRC 2013/62 (Bucur en Toma t. Bulgarije). 
was van de aard van de in de inbeslaggenomen documenten vervatte verklaring en dat de rechtbank in raadkamer daarom kennis had moeten nemen van de inhoud van de documenten. ${ }^{249}$

Voorts kan worden gewezen op een zaak rond inbeslagneming onder een notaris in geval van 'zeer uitzonderlijke omstandigheden'. De Hoge Raad overwoog dat het de taak van de rechtbank is, oordelend uit hoofde van artikel $552 \mathrm{a}$ Sv, om zich 'aan de hand van de stukken en het onderzoek in raadkamer' een eigen, zelfstandig oordeel te vormen over de vraag of er sprake is van 'zeer uitzonderlijke omstandigheden'. ${ }^{25}$ Het ligt voor de hand dat in dit verband onder 'de stukken' juist ook de inbeslaggenomen stukken moeten worden verstaan, met name omdat volgens vaste rechtspraak de aard van de inbeslaggenomen gegevens mede bepalend is voor het antwoord op de vraag of er sprake is van zeer uitzonderlijke omstandigheden.

\section{Schending van het verschoningsrecht: het onderzoek ter terechtzitting}

Is de verschoningsgerechtigde - of een andere belanghebbende - in de procedure op de voet van artikel 552a Sv niet, dan wel niet met succes opgekomen tegen een beweerde schending van het verschoningsrecht in het kader van beslag en doorzoeking, dan kan ter zitting een beroep worden gedaan op schending van het verschoningsrecht. De rechter in de hoofdzaak beslist in dat geval zelfstandig over de vraag of het verschoningsrecht is geschonden, zonder het oordeel van de verschoningsgerechtigde over de reikwijdte van het verschoningsrecht te hoeven inwinnen. In Nederland wordt het antwoord op de vraag tot welke gevolgen een vormverzuim in het vooronderzoek moet leiden beheerst door artikel 359a Sv, dat een scala van mogelijkheden geeft: van de declaratoire uitspraak dat een vormverzuim is begaan maar dat daaraan geen gevolgen behoeven te worden verbonden, tot de niet-ontvankelijkverklaring van het Openbaar Ministerie in de vervolging. In verschillende arresten heeft de Hoge Raad nadere voorschriften gegeven omtrent de toepassing van artikel 359a Sv, dat bij de invoering werd gezien als de codificatie van de normen die reeds in de rechtspraak waren vastgelegd. ${ }^{251}$ In het overzichtsarrest van ig februari 2013 , LJN BY $532 \mathrm{I}^{252}$ wordt, evenals in de Belgische rechtspraak het geval is, het recht op een eerlijk proces in de zin van artikel 6 EVRM centraal gesteld en wordt aangegeven in welke gevallen bewijsuitsluiting een passende reactie is op een verzuim in het voorbereidend onderzoek. Ook wanneer het recht op een eerlijk proces

249 HR 2I december 20I0, LJN BLo666, NJ 20II, 425, m.nt. J.M. Reijntjes.

250 HR I5 mei 2007, LJN BA049I, NJ 2007, 300.

25I In zoverre is er een parallel met het recht in België, waar het voornemen bestaat de zogenoemde Antigoon-toets in de wet vast te leggen (Wetsontwerp tot wijziging van de voorafgaande titel van het Wetboek van strafvordering, Wetgevingsstuk 5-I924/3).

252 NJ 2013, 308, m.nt. B.F. Keulen, die de aandacht vraagt voor de vraag of de Hoge Raad in dit arrest niet te veel voor de muziek uitloopt: 'Mij bekroop bij dit arrest het gevoel dat het misschien wel een beetje te hard gaat.' Het arrest vormt een vervolg op onder meer HR 30 maart 2004, LJN AM2533, NJ 2004, 376, m.nt. YB. Kortheidshalve verwijs ik naar de in de annotaties bij beide arresten genoemde literatuur. 
niet rechtstreeks aan de orde is, maar sprake is van een ander belangrijk voorschrift of rechtsbeginsel dat in aanzienlijke mate is geschonden, kan toepassing van bewijsuitsluiting noodzakelijk worden geacht als middel om toekomstige vergelijkbare vormverzuimen te voorkomen en een krachtige stimulans te laten bestaan tot handelen in overeenstemming met de voorgeschreven norm, aldus het arrest. Daarbij kan onder meer gedacht worden aan gevallen 'waarin het gebruik voor het bewijs wezenlijk afbreuk doet aan het fundamentele belang dat met de bescherming van het professionele verschoningsrecht is gediend'. Of daadwerkelijk materiaal moet worden uitgesloten van het bewijs is afhankelijk van de omstandigheden van het geval. De Hoge Raad voegt daaraan in genoemd arrest toe dat de rechter bij die afweging kan betrekken of in de gegeven omstandigheden toepassing van bewijsuitsluiting opweegt tegen de daarvan te verwachten negatieve effecten en of aldus niet op onaanvaardbare wijze afbreuk wordt gedaan aan zwaarwegende belangen als de waarheidsvinding en de bestraffing van de dader van een - mogelijk zeer ernstig - strafbaar feit, alsmede in voorkomende gevallen aan de rechten van slachtoffers of hun nabestaanden, mede gelet op uit het EVRM voortvloeiende positieve verplichtingen tot effectieve bestraffing.

Toepassing van artikel 359a Sv komt echter niet in beeld wanneer de rechter(-commissaris) heeft geoordeeld dat er, al dan niet tegen de achtergrond van de positieve verdragsverplichtingen, zeer uitzonderlijke omstandigheden zijn op grond waarvan door doorzoeking en beslag een inbreuk kan worden gemaakt op het verschoningsrecht. Dan immers is er geen sprake van een vormverzuim als bedoeld in artikel 359a Sv.

\section{I2 Tot besluit}

De wettelijke regeling geeft al lange tijd geen betrouwbaar beeld meer van de stand van zaken rond het verschoningsrecht. Voor de jurist is het lastig om een overzicht te krijgen van de problematiek, voor de verschoningsgerechtigde die geen jurist is, is dat nog veel gecompliceerder. Het is dan ook de hoogste tijd om in ieder geval de hoofdlijnen van de rechtspraak over beslag en doorzoeking bij de verschoningsgerechtigde in de wet op te nemen. De tijd lijkt bovendien rijp te zijn voor codificatie van het concept 'zeer uitzonderlijke omstandigheden' waaronder een inbreuk op het verschoningsrecht kan worden gemaakt. ${ }^{253}$

Ook andere zaken vragen de aandacht. De positie van de cliënt en de patiënt in het kader van het verschoningsrecht verdient nadere overweging. De begrippen 'goed', 'gegeven' en 'voorwerp' moeten beter worden doordacht. Voor de bepaling van de reikwijdte van het beklag uit hoofde van artikel $552 \mathrm{a} \mathrm{Sv}$ - ongeacht of het gaat om beslag waarbij het verschoningsrecht is betrokken - zou niet langer de aard van de drager van de gegevens doorslaggevend moeten zijn, maar moet worden gestreefd

253 Ook het in de wet vastleggen van de verschillende categorieën 'zeer uitzonderlijke omstandigheden' heeft mijn voorkeur, ook al is uiteraard niet uit te sluiten dat in de rechtspraak het concept 'zeer uitzonderlijke omstandigheden' zich verder zal ontwikkelen. 
naar een regeling die geen onderscheid maakt naar de wijze waarop de gegevens technisch gesproken zijn vastgelegd.

Een en ander neemt niet weg dat binnen het alsdan door de wet geschetste kader en uitgaande van het grote belang van het verschoningsrecht voor het individu en voor de samenleving, in het concrete geval moet worden gezocht naar evenwicht tussen de verschillende belangen die gewicht in de schaal leggen bij de beantwoording van de vraag of in zeer uitzonderlijke omstandigheden een inbreuk moet worden gemaakt op het verschoningsrecht. Bij die afweging zijn de omstandigheden van het geval van groot belang. Dat is en blijft maatwerk, dat niet in een wettelijke regeling is te vangen.

Het verschoningsrecht staat of valt met vertrouwen. Vertrouwen van de patiënt of cliënt in arts, advocaat of notaris, vertrouwen van de samenleving in de onkreukbaarheid van de verschoningsgerechtigde. Van het grootste belang is daarom dat de beroepsgroep orde op zaken stelt en houdt in eigen gelederen. Wankelend vertrouwen is de grootste bedreiging van het verschoningsrecht. 